\title{
Evolución del parcelario doméstico y su inte- racción con la trama urbana: el caso de los arrabales califales de Córdoba
}

\author{
Evolution of the domestic plot and its interaction with the urban fabric: \\ the case of the caliph slums of Cordoba \\ Cristina Camacho Cruz \\ Recibido 8/12/2017 - Aprobado 23/7/2018
}

\begin{abstract}
RESUMEN
El presente trabajo recoge el análisis de parte de los resultados obtenidos durante las Actividades Arqueológicas desarrolladas entre los años 2000 y 2008, en el trazado de la actual Ronda Oeste de Córdoba. El marco espacial analizado será el parcelario doméstico que se genera a occidente de la ancestral Madinat Qurtuba y el marco cronológico será aquél en el que se desarrolla esta expansión extramuros, los siglos IX y XI. Nuestro análisis se ha centrado en reconocer en el parcelario definido los diferentes procesos de constitución, expansión y saturación urbanos.
\end{abstract}

Palabras clave: Al-Andalus. Arqueología de los espacios. Tramas urbanas. Casa islámica.

\section{INTRODUCCIÓN}

El presente trabajo recoge el análisis de parte de los resultados obtenidos durante las Actividades Arqueológicas desarrolladas entre los años 2000 y 2008, en el trazado de la actual Ronda Oeste de Córdoba. Con algo más de 5 $\mathrm{km}$ lineales, a aproximadamente $1,5 \mathrm{~km}$ del que fuera recinto amurallado de la ciudad histórica, esta obra de infraestructura cruza de norte a sur toda el área a Poniente de la Córdoba actual. El marco espacial analizado será así el parcelario doméstico que se genera a occidente de la ancestral Madinat Qurtuba y el marco cronológico será aquél en el que se desarrolla esta expansión extramuros, los siglos IX y XI.

Los terrenos en los que se proyectó la obra eran en su mayoría un baldío de antiguas huertas, en pleno proceso de urbanización desde

\begin{abstract}
This work includes the analysis of part of the results obtained during the archaeological activities carried out between the years 2000 and 2008 in the Round West of Cordoba. In the place we could provide evidence of one of the western outskits ("arrabales") of Madinat Qurtuba, as a result of the great growth of the city during the 9th and the 11th centuries. Our analysis has focused on recognizing in the plot defined different urban processes of creation, expansion and saturation.
\end{abstract}

Key words: Al-Andalus. Household Archaeology. Urban pattern. Islamic house

los años 80 del pasado siglo. La superficie había sufrido alteraciones debidas a la roturación del terreno para el cultivo, y a aportes de muladares y escombreras a lo largo de siglos de vigencia. Sin embargo, esta circunstancia de ser un terreno prácticamente "virgen" urbanísticamente ha favorecido notablemente la conservación de la estratigrafía arqueológica, siendo escasas las intrusiones y alteraciones posteriores al último abandono habitacional producido y documentado.

Desde que comenzaron las tareas arqueológicas en la Ronda Oeste de Córdoba, venimos realizando estudios sectorizados de las distintas áreas intervenidas, así como análisis puntuales de diferentes ítems. La puesta a disposición del análisis preliminar de los resultados obtenidos y la generosa revisión de los mismos por parte de otros colegas

\footnotetext{
* Arqueóloga Colegiada n 2712 CDL Córdoba.
} 
investigadores, lograron salvar las deficiencias y dudas metodológicas manifiestas a priori (MURILLO, CASAL y CASTRO, 2004, 267; VAQUERIZO y MURILLO, 2010, 539), convirtiendo la Intervención Arqueológica de Urgencia objeto de este artículo en refrendo a múltiples estudios de referencia ${ }^{1}$. Gracias a los resultados obtenidos con la excavación del ámbito ocupado por ésta y otras obras públicas -junto a innumerables promociones privadas-, se ha ampliado de un modo notable nuestro conocimiento acerca de la ocupación de este sector extramuros de la ciudad histórica.

La línea de trabajo iniciada de forma meritoria por Acién y Vallejo en 1998, y retomada por Murillo, Casal y Castro en 2004, sentaría las bases del estudio diacrónico de la topografía urbana de Madinat Qurtuba, haciendo hincapié, por encima de todo, en el proceso histórico que la determina y en los cambios en el paisaje urbano que definen su configuración. En esta búsqueda de respuestas, se introdujo el concepto de islamización, entendida como el conjunto de actuaciones urbanísticas y arquitectónicas islámicas introducidas desde los primeros momentos de formación de la urbe emiral, que favoreció la proliferación de elementos típicamente islámicos en el parcelario urbano extramuros, como cementerios, almunias, baños o mezquitas (ACIÉN y VALLEJO, 1998, 113; MURILLO, CASAL y CASTRO, 2004, 264-265, 268). Ya en 2010, sobre la base del análisis riguroso de la información arqueológica de la que se disponía, una última publicación de conjunto recogió todas estas novedades metodológicas (VAQUERIZO y MURILLO, 2010), analizando en qué términos físicos se concre- ta la islamización de la totalidad del espacio urbano, y cómo, cuándo y en función de qué precedentes se desarrolla dicho espacio.

No obstante, y a pesar del tiempo transcurrido desde los primeros análisis en los años 90, no todo está dicho sobre la ocupación medieval constatada en estos ensanches. La puesta en común y contrastación de ideas, en los que el trabajo de carácter interdisciplinary colaborativo se erige como un valor de primer orden para conseguir y garantizar la calidad del estudio arqueológico, nos llevó al análisis de los vestigios exhumados en Ronda Oeste de Córdoba, bajo las directrices del Laboratorio de Arqueología y Arquitectura de la Ciudad de la Escuela de Estudios Árabes del C.S.I.C. en Granada, en especial de los profesores Julio Navarro y Pedro Jiménez ${ }^{2}$.

Por un lado, siguiendo el desarrollo conceptual de Navarro y Jiménez (NAVARRO y JIMENEZ, 2004), tratamos de discernir qué procesos evolutivos tienen lugar, a lo largo de la etapa medieval islámica, en el espacio ocupado por la actual Ronda Oeste. Nuestro análisis se ha centrado en reconocer, en el parcelario de cada uno de los sectores definidos, algunos de dichos procesos: constitución, expansión, saturación y desbordamiento. Por otro lado, siguiendo los tres niveles de análisis del hecho doméstico -morfológico, sintáctico y dimensión semiótica- de Gutiérrez Lloret (GUTIÉRREZ LLORET, 2012), tratamos de identificar las formas de organización espacial resultantes: dispersa o diseminada y la colindante, que puede presentarse a su vez en organización lineal, agrupada o en trama ${ }^{3}$.

1 El volumen de la documentación resultante nos ha permitido hasta el momento hacer estudios por sectores y de material asociado (CAMACHO 2002, 2004, 2007, 2008, 2008a, 2015; CAMACHO y HARO 2010, 2013; CAMACHO et alii, 2004, 2007, 2009a, 2009b, 2009c, 2009d, 2009e; HARO y CAMACHO, 2007; CANTO y CAMACHO 2009). Además, dicha documentación ha sido incluida total o parcialmente en estudios arqueológicos sistematizados de elementos urbanos tales como espacios funerarios (CASAL, 2003; CASAL ET ALII, 2006), mezquitas (GONZÁLEZ GUTIÉRREZ, 2012; 2016), arquitectura doméstica (CASTRO, 2005; BLANCO, 2014), sistemas hidráulicos (VÁZQUEZ, 2010; 2013; 2016), almunias (LÓPEZ CUEVAS, 2013), espacios industriales (SALINAS, 2012), etcétera.

2 Este análisis se desarrolló en el marco del Proyecto de Investigación "La arquitectura residencial de al-Andalus: análisis tipológico, contexto urbano y sociológico. Bases para la intervención patrimonial” (HAR2011-29963), del Plan Nacional de I+D+i y enmarcado en el VI Plan Nacional de Investigación Científica, Desarrollo e Innovación Tecnológica 2008-2011.

3 Gutiérrez Lloret, 2012, 140, define tres niveles distintos de análisis del hecho doméstico: el morfológico, que se ocupa de la forma de las unidades domésticas y de las modificaciones o transformaciones que experimentan; el sintáctico que enfatiza las relaciones entre las estructuras elementales y, al modo del lenguaje, las percibe en el marco de una estructura espacial organizada más compleja. Y, por fin, la dimensión semiótica, que las analiza como expresiones sociales, materialización e instrumento de significados culturales, y se centra en el uso social del entorno construido, es decir, en las relaciones entre los espacios construidos y la estructura social que los concibe y ejecuta a través de expresiones arquitectónicas concretas. 
Para dicho análisis, se dividió la totalidad del área intervenida, ahora considerada como un único yacimiento, en cuatro sectores. Cada sector fue definido por su articulación respecto a una o varias de las vías principales de conexión entre la Medina y los arrabales (Fig. 1):

SECTOR 1: Avenida Menéndez Pidal, con una superficie intervenida en torno a los 15.000 $\mathrm{m}^{2}$, se sitúa respecto al viario principal entre el Camino de las Almunias al sur ${ }^{4}$, y el Camino Nuevo de Almodóvar al norte ${ }^{5}$, ambos en conexión con Bab Isbiliya. Conectando los dos caminos principales documentamos un Camino Intermedio, que cruza la superficie de excavación.

Este es el único caso en el que la lectura de las fuentes nos permite una identificación de los vestigios documentados. Según

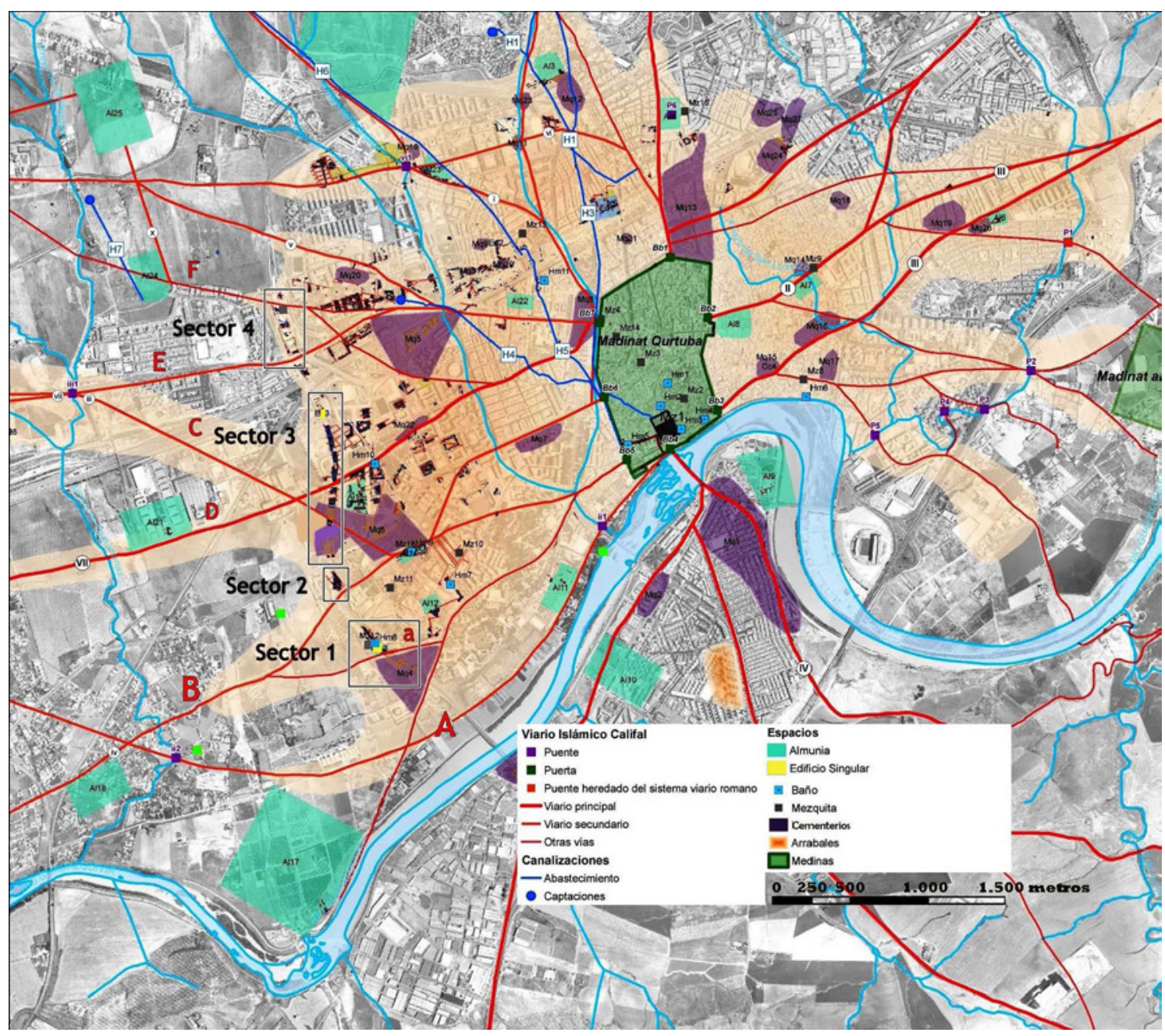

Fig. 1. Topografía urbana de Qurtuba a finales del siglo X (sobre VAQUERIZO y MURILLO (Eds.) 2010, fig. 251). Propuesta de restitución trama urbana Sectores 1-2-3-4 Ronda Oeste de Córdoba (CAMACHO 20012012). SECTORES RONDA: 1. Avenida Menéndez Pidal. 2. Casas del Naranjal. 3. Carretera del Aerpuerto. 4. Carretera de Palma del Río. CAMINOS: A. Camino de las Almunias. a. Camino Intermedio. B. Camino Nuevo de Almodóvar. C. Camino de las Abejorreras. D. Camino Viejo de Almodóvar. E. Cañada Real Soriana. F. Camino de la Matriz o Carril de los Toros.

4 El primer resto arqueológico de este camino principal entre Qurtuba y Madinnat al-Zahrā' es el puente califal localizado sobre el arroyo Cantarranas (PAVÓN, 1990, 106).

5 Los Caminos a Almodóvar, convertidos en calles a medida que se urbanizan las áreas periurbanas que atraviesan, se han localizado en zonas más al este de la que nos encontramos, en parcelas del Polígono 1 del Plan Parcial de Poniente y Avenida del Aeropuerto (MURILLO, CASAL y CASTRO, 2004, 269). 
al-Rāzì, el 19 de septiembre de 971, tiene lugar una parada militar organizada por el califa con motivo de la llegada a Córdoba de Ya'far y Yahyā, los dos hijos de 'Alì ibn al-Andalusi. Se describe el itinerario de los visitantes desde Córdoba hasta la almunia de Ibn 'Abd al-'Aziz, donde se alojarían antes de ser recibidos por el califa en Madinat al-Zahrā'. Según el itinerario descrito pasaron por la explanada del Alcázar, siguieron hasta el final de la Medina, hasta salir a campo abierto por la Musāra. De alli se les hizo torcer por la cuesta en cuyo alto está la mezquita del hāyib 'Isā ibn Ahmmad ibn Abi 'Abda, y luego por el arrabal de la mezquita de al-Šifā' y por el arrabal del Hammām de al-Ilbìrī, hasta llegar a la mencionada almunia (IBN HAYYĀN, trad. E. García Gómez, 1967, 66). Reconocido el itinerario por el denominado Camino de las Almunias para llegar a su destino, probablemente en torno a Llanos del Castillo, si el arrabal y la mezquita de al-Šifā' está claramente documentado entre el Parque Cruz Conde y el Parque Deportivo Fontanar, estaríamos pues en el segundo de los arrabales mencionados, el arrabal del baño de Elvira.

SECTOR 2: Casas del Naranjal, con una superficie intervenida de $5.000 \mathrm{~m}^{2}$, situado respecto al viario principal entre el Camino Nuevo de Almodóvar al sur y el Camino
Viejo de Almodóvar al norte, en conexión con Bab al-Yawz.

SECTOR 3: Carretera del Aeropuerto, con una superficie intervenida en torno a los 50.000 $\mathrm{m}^{2}$, situado entre el Camino Nuevo de Almodóvar al sury la Cañada Real Soriana al norte, en conexión con Bab Amir y con Bab al-Yawz. Por él discurren dos vías principales de acceso a la ciudad que, como veremos, delimitan áreas de desarrollo diferencial dentro del mismo: el Camino de las Abejorreras ${ }^{6}$, documentado durante la excavación, y el mencionado Camino Viejo de Almodóvar, fosilizado en la carretera de acceso a la fábrica ABB.

SECTOR 4: Carretera de Palma del Río, con una superficie intervenida en torno a los 17.000 $\mathrm{m}^{2}$, situado entre la Cañada Real Soriana, al sur, y la Vereda de Trassierra, al norte, en conexión con Bab Amir, por él discurre también parte del viario occidental de la ciudad: el conocido como Camino de la Matriz o Carril de los Toros (BERMúdDEZ, 1993, 269).

\section{DESCRIPCIÓN DE LA INTERVENCIÓN ARQUEOLÓGICA}

La secuencia estratigráfica de los sectores intervenidos es la siguiente (Fig. 2):

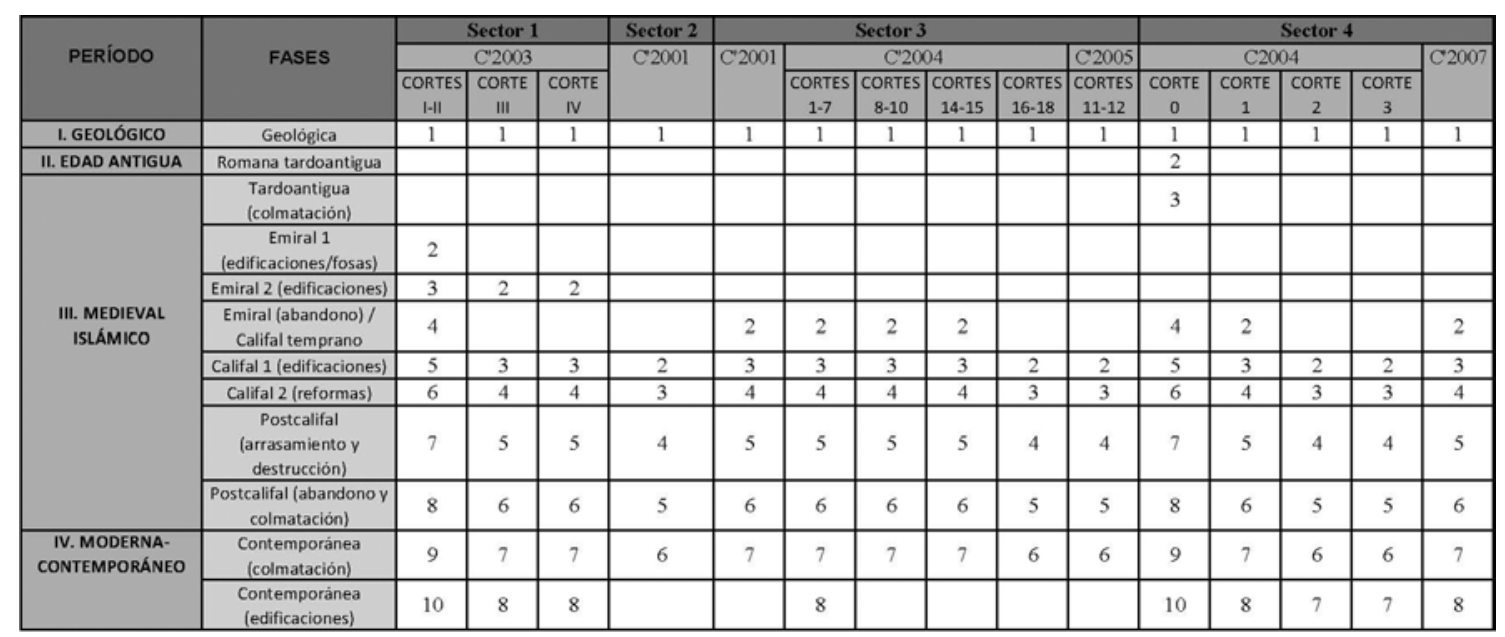

Fig. 2. Resumen secuencia estratigráfica por sectores y campañas de excavación Ronda Oeste de Córdoba.

6 El Camino de las Abejorreras ha sido arqueológicamente documentado más al este, en Calle Pintor Espinoza (RUIZ, MURILLO y MORENO, 2001, 161). 


\subsection{Fase emiral $y / 0$ califal temprano}

Presente en los Sectores 1, 3 y 4, es en el SECTOR 1 donde esta primera etapa tiene más desarrollo. Documentamos una primera fase fundacional emiral, fechada a finales del siglo VIII O inicios del IX, con vestigios amortizados en su mayor parte por los de la siguiente fase. Se trata de estructuras de escasa densidad y técnica edilicia elemental y económica: algunas fosas-basurero, muros con cimentación de cantos rodados y guijarros y alzado de mampostería careada de arenisca -cuyo trazado se fosiliza y persiste en las fases subsiguientes- $y$ algunos pozos. La escasez de datos no nos permite precisar cómo se originan las estructuras mencionadas, pero sería lógico pensar que se corresponderían con un edificio primigenio rodeado por huertas y tierra de labor, perteneciente quizá a una alquería anterior a la expansión urbanística que se desarrolla en las siguientes fases.

A una segunda fase emiral, fechada en el siglo IX, corrresponderían parte de las alineaciones murarias de un gran edificio residencial culminado en la etapa posterior, las primeras unidades domésticas germen del arrabal, la primera fase de un área cementerial y algunas estructuras que pueden interpretarse como el binomio baño-mezquita (Lám. 11). En esta segunda fase se utilizan materiales y técnicas más sofisticados o complejos. Las alineaciones documentadas, en algún caso, actúan como cimentación de los muros de la siguiente fase, condicionando el trazado y orientación de las estructuras de arrabal califal situado al norte. Dependiendo de las dimensiones y características de los espacios que delimitan, la edilicia de los muros varía. Documentamos muros con cimentación de guijarros y cantos rodados y alzado de mampostería careada de arenisca, en algún caso con sillares dispuestos en vertical, y pilares de sillería en forma de T invertida, trasunto del clásico opus africanum también documentado en el rasif de 'Abd al-Rạ̣mān II (LEÓN MUÑOZ, 2006, 422); muros de sillares de calcarenita dispuestos a soga, intercalados con rellenos de mampostería; y muros de grandes sillares de calcarenita, dispuestos a tizón en la cimentación y a soga y tizón en el alzado (Lám. 1).

Tanto la creación del cementerio (con 2721 inhumaciones superpuestas en hasta cuatro niveles de enterramiento), como de la
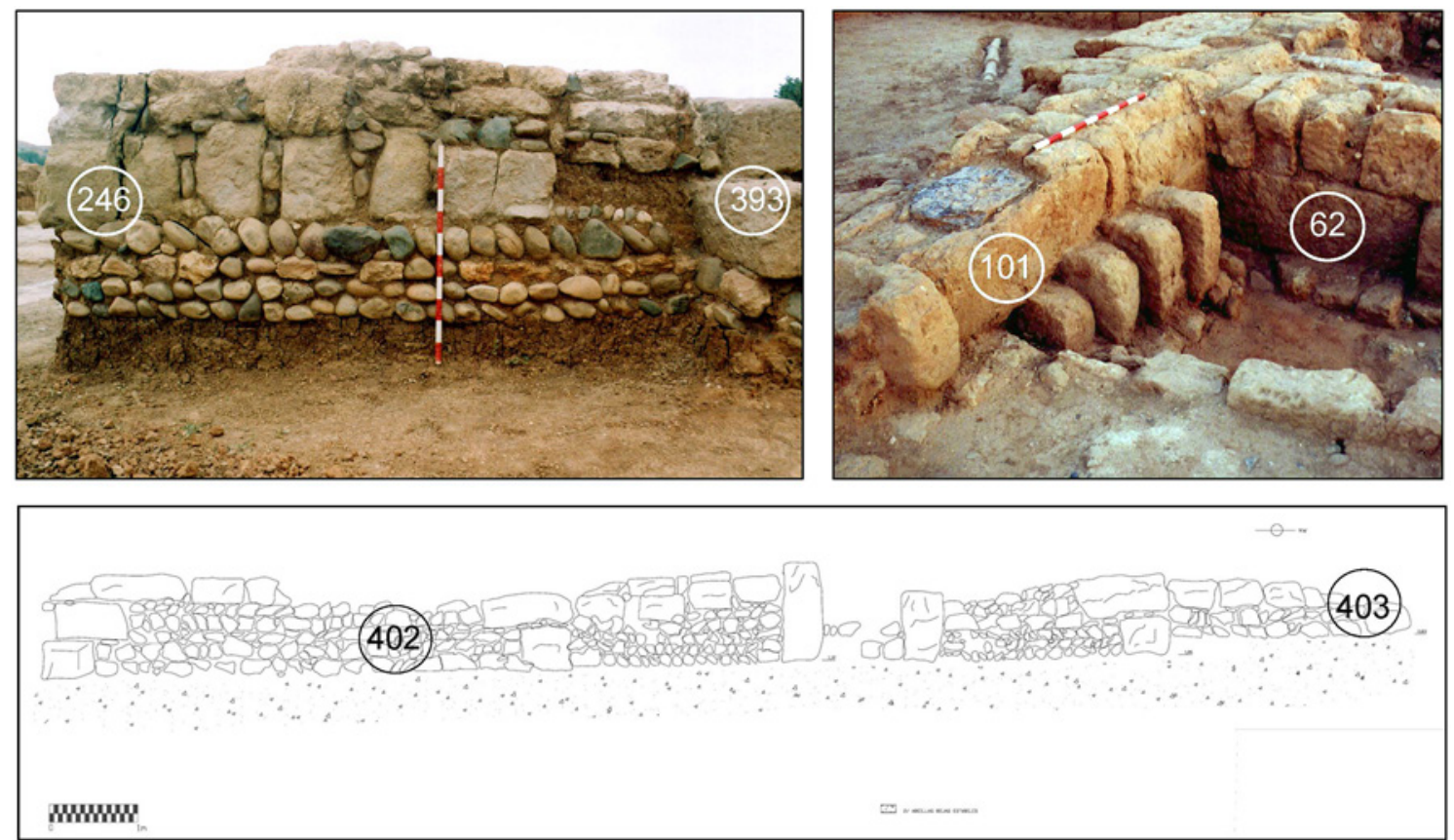

Lám. 1. a) Sector 1. Configuración fachadas Calles A y B. Emiral 2. Fase 3. UU.EE. 246, 393. b) Sector 1. Crujía oriental patio 2. Califal 1. Fase 5. UU.EE. 62, 101. c) Sector 1. Muro cierre oriental mezquita. Emiral 2. Fase 3. UE.402. Califal 1. Fase 5. UE.403. 
mezquita creemos respondería, al igual que en el resto de los cementerios localizados en Ronda Oeste de Córdoba, a una dinámica muy común en época islámica, la de donación de habices, dación de inmuebles -edificios y áreas de explotación rural- a instituciones religiosas, como el caso de los cementerios y las mezquitas, por parte de sus propietarios.

Las técnicas y materiales empleados en esta segunda fase emiral, así como los diferentes ámbitos definidos nos hablan de un gran edificio residencial, de rasgos palatinos, rodeado en origen de tierras de labor y jardines que constituirá el germen del arrabal que se originará en la fase inmediatamente posterior, fase califal temprana. El edificio se ordena en grandes crujías paralelas distribuidas en torno a grandes patios y corredores que actuarían como articuladores de los espacios públicos y de representación con las zonas privadas y de servicio de la vivienda?

El acceso principal al edificio documentado se sitúa en el frente norte de uno de los caminos principales de la ciudad, el llamado Camino Intermedio que conectaría el Camino de Casillas con el Camino Nuevo de Almodóvar y éste, a su vez, con el Camino de las Almunias. En el frente sur, se localiza una única vivienda y el área cementerial. En los 60 m de longitud exhumados, el camino presenta una anchura variable de entre 11 y 17 m y distinguimos hasta tres unidades de pavimentación de cantos, gravas y gravillas.

El segundo de los accesos documentados en este edificio singular se sitúa en el extremo opuesto, desde el tramo cerrado de la denominada Calle D, de trazado sur-norte, $2 \mathrm{~m}$ de achura y 18,80 m de longitud, con acceso desde la denominada Calle A, segundo de los ejes este-oeste exhumados. La Calle A presenta una anchura variable entre 4,05 m y los 1,75 m. En el frente sur de esta Calle A, además de este adarve de acceso único al edificio, documentamos el acceso al baño, a occidente, y a una vivienda, a oriente. En el frente norte se abre el tramo septentrional de la Calle D, y una tercera vía, Calle B, configurada con la edificación de la mezquita. Contiene el acceso a cuatro viviendas. En su alineación se observan diversas desviaciones, derivadas de su configuración inicial y su propia evolución. Además de distinguir tres niveles de suelo, documentamos dos fases constructivas en relación a los dispositivos hidráulicos, sin que hayamos podido determinar los momentos concretos en los que éstos fueron establecidos.

La diferente edilicia de las atarjeas de la Calle A y tramo sur de la Calle D, cuyas dimensiones exceden lo que suele ser habitual en otros arrabales, con cloacas que discurren por la zona central caracterizadas por una cubierta realizada con losas de calcarenita de unos 0,40 $\mathrm{m}$, podría indicarnos que la construcción de estas vías estaría en relación con la decisión del gran propietario de las tierras sobre las que se construye el edificio mencionado de, en un determinado momento, urbanizar su propiedad (Lámina 5), iniciativa privada o pública difícil de determinar.

En los SECTORES 3 y 4 , a la fase califal temprana corresponderían por un lado, una serie de estructuras hidráulicas -atanores, pozos noria y albercas- y muladares, en distintos puntos de la excavación, en ocasiones amortizadas y en otras mantenidas y reutilizadas en la fase subsiguiente. Junto a dichas estructuras hidráulicas, en el área más meridional del

\footnotetext{
7 No estaríamos ante una almunia propiamente dicha. E. García Gómez definió la almunia como una casa de campo, rodeada de un poco o de mucho jardín y de tierras de labor que servía de residencia ocasional y era, al mismo tiempo, finca de recreo y explotación (GARCÍA GÓMEZ, 1965, 334). Las fuentes históricas nos han transmitido diversos términos para nombrar estas edificaciones en Córdoba y sus alrededores: dar, balat, munya, qasr y hair. Aun cuando la utilización de expresiones diferentes induce a pensar en tipos de palacio diferentes, la correlación entre los distintos términos y las características de las estructuras/edificios registradas por la arqueología rara vez es posible. Que los límites entre los distintos conceptos no están claros lo confirma el hecho de que para el mismo edificio se usan palabras diversas y que las fuentes rara vez hablan de rendimientos agrícolas y sí del uso concreto de los edificios residenciales de la munya, como lugar de descanso temporal de los propietarios, realización ocasional de tareas de gobierno, celebración de fiestas o acogida de huéspedes (LÓPEZ CUEVAS, 2013, 252). Quizá éste sería el caso que nos ocupa, pero hasta el momento no hemos identificado los restos del edificio original con ninguna de las almunias aparecidas en las fuentes.
} 
Sector 3 se localizan una serie de estructuras murarias de mampostería o sillarejos dispuestos en hiladas, alternando con piedras aristadas, pertenecientes a un edificio para el que no tenemos una interpretación clara, pero que, sin duda, estaría asociado a un área de huertas y tierra de labor previa a la expansión urbanística y cementerial que se desarrolla en época califal.

\subsection{Fase califal}

En los cuatro sectores estudiados la etapa califal se caracteriza por ser el momento de mayor eclosión urbanística, en el que se genera y desarrolla un parcelario más o menos denso y en continua evolución hasta su abandono.

En el SECTOR 1 asociamos a esta fase la reedificación de amplios sectores de los edificios emirales antes mencionados (gran residencia-baño-mezquita) ${ }^{8}$ y la definitiva constitución de la trama urbana del arrabal iniciado en la etapa precedente. El parcelario quedará estructurado, además de por el Camino Intermedio, por cinco ejes viarios (Lámina 11). Tres de estos ejes, Calles A, B y D, están ya configurados, como hemos visto, desde el momento de fundación del arrabal en la segunda fase emiral, y dos, Calles C y E, serán edificados en la fase plenamente califal. A este viario abren 28 unidades domésticas (15 casas completas o legibles en toda su planimetría y restos pertenecientes a otras 13, excavadas sólo de forma parcial). Dentro de la etapa califal ha sido posible determinar la existencia de una serie de reformas de cronología indeterminada, en el viario y en 18 de las 28 viviendas documentadas, que ponen de manifiesto la continua evolución del arrabal hasta su abandono.
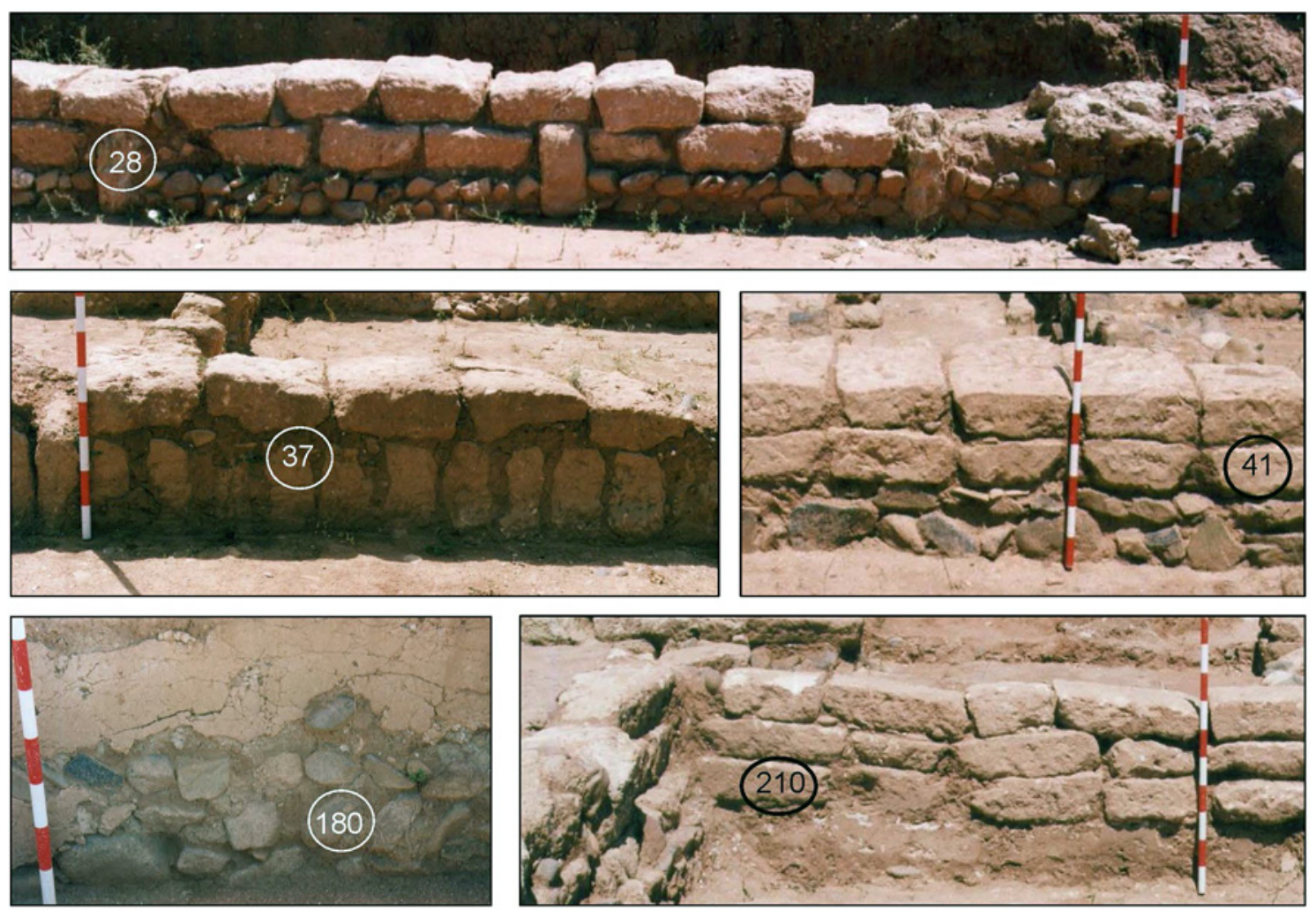

Lám.2. a-d) Sector 2. Estructuras murarias UU.EE. 28, 37, 41, 180. Califal 1. Fase 2. e) Sector 2. Estructura muraria UE.210. Califal 2. Fase 3.

8 Con aparejos omeyas de sillares de 1,20 × 0,20 × 1,05 m, dispuestos a tizón en las cimentaciones y con un alzado en el que alternan dos sogas y tres o cuatro tizones con el interior relleno de ripios, mampuestos o guijarros (RUIZ LARA ET ALII, 2008, 177). 

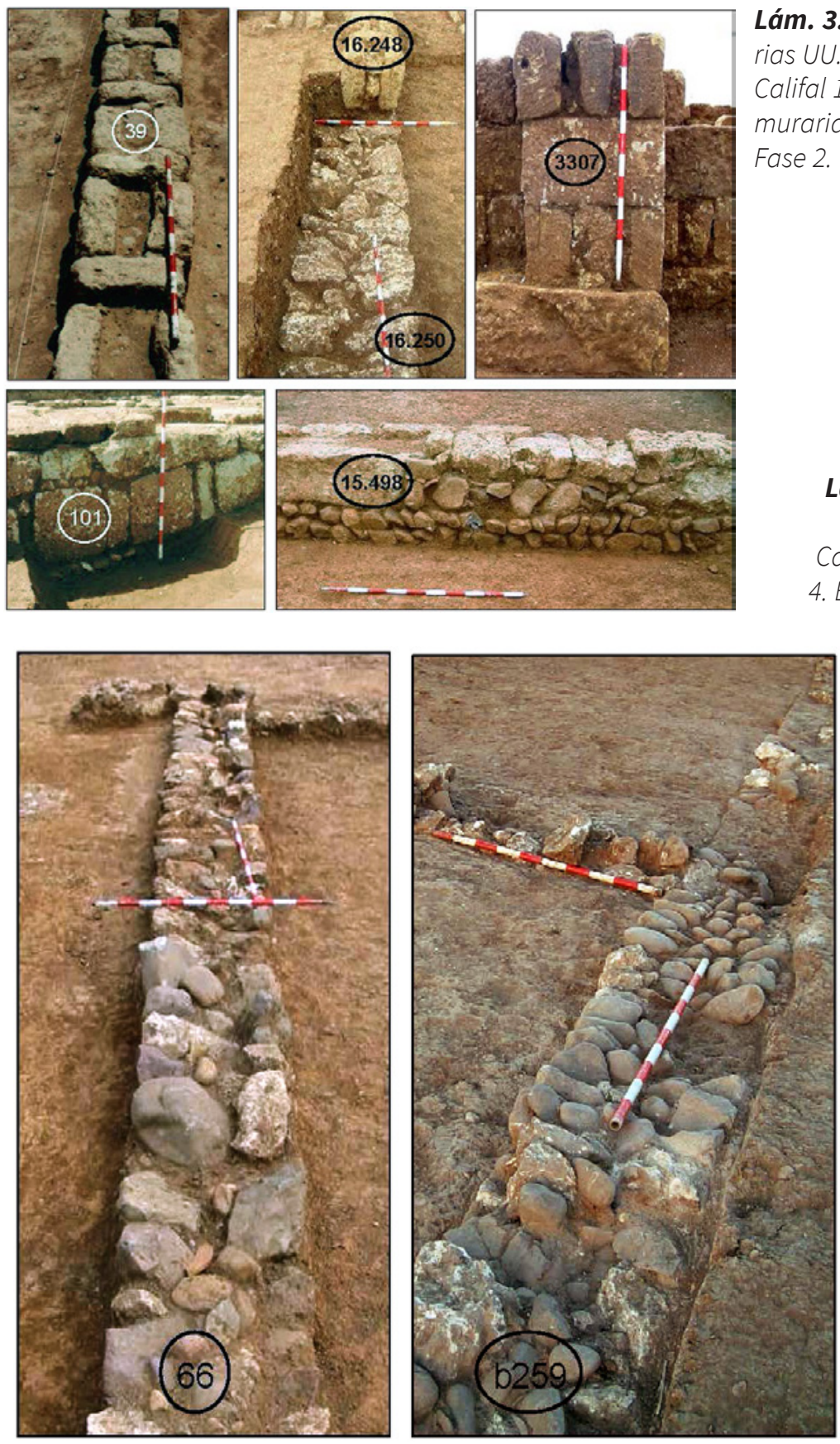

Lám. 4. a-c) Sector 4. Estructuras murarias UU.EE. 66, b259, b265. Califal temprano. Fase 4. d) Sector 4. Estructuras murarias UU.EE. 253, b248. Califal. Fase 5.
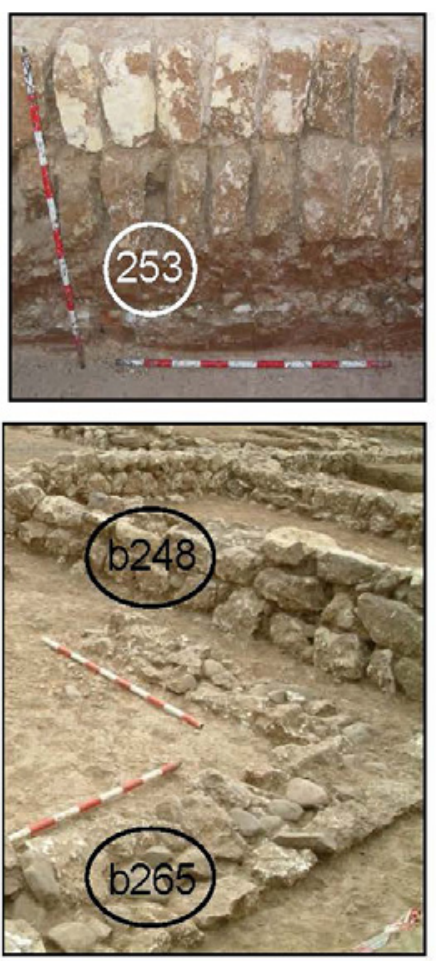

El desarrollo norte de la Calle B ya en la etapa califal presenta una anchura media de 2,95 y 2,85 m. Aunque documentamos sólo 33,70 metros de su longitud, la prolongación de las crujías de fachada de las viviendas documentadas nos ha permitido definir su trazado, que superaría los $100 \mathrm{~m}$ de longitud. Como hemos indicado, su construcción viene determinada por la parcelación de los terrenos anejos a la mezquita; pero mientras la Calle $\mathrm{A}$ se origina como resultado de la construcción de dos grandes edificios, cuyas fachadas configuran el espacio público residual, la Calle B y el tramo norte de la Calle D son probablemente creadas por un proceso de parcelación del espacio, con ulterior edificación de los inmuebles. Aun cuando su frente occidental muestra algunas realineaciones derivadas de la probable edificación por lotes, el espacio viario parece generado en una única fase constructiva. Aunque se evidencia que la introducción de la red de evacuación de aguas 
se inició con el levantamiento de las canalizaciones principales o primarias, que fueron las encargadas de recoger las aguas procedentes de los canalillos secundarios que atravesaban las viviendas, distinguimos dos niveles de suelo y sendas reestructuraciones de la red de evacuación, posiblemente en relación con modificaciones del parcelario doméstico o con algún fenómeno meteorológico que hubiera colapsado el alcantarillado previo.

Por su parte, el desarrollo norte de la Calle D en esta etapa presenta una anchura de 3,25 m. Aunque documentamos sólo 46,70 metros de su longitud, el eje viario que se define superaría los 125 m lineales. La realineación de la fachada entre las viviendas 3 y 13, indica su edificación en diferentes fases constructivas. Distinguimos asimismo dos niveles de suelo, y dos fases constructivas en relación a los dispositivos hidráulicos.

También en la fase califal, en el tramo de fachada de la Calle A al baño esta vía se estrecha, en un momento indeterminado, quizá para evitar que los humos del mismo llegaran al oratorio cuyo mihrab se sitúa enfrente. El nuevo muro de fachada se apoya sobre la pared de la atarjea original y la amortiza. Se produce una invasión del espacio público que hace necesaria la construcción de una segunda atarjea.

Finalmente, en esta etapa se edifica la Calle $\mathrm{C}$, de trazado este-oeste, de la que documentamos $20 \mathrm{~m}$ de su longitud y una anchura diferencial de 2,75 m en su tramo oeste y $3,98 \mathrm{~m}$ en su tramo este. Las relaciones entre estratos no han quedado tan claras, por la pérdida de la atarjea central, pero podemos comprobar el descanso de los canalillos domésticos sobre el suelo del viario y las roturas provocadas en el mismo por las fosas sépticas. En cuanto a los modos constructivos, las atarjeas principales muestran cierta "uniformidad", mientras que las secundarias alternan diferentes soluciones. La Calle E, de trazado norte-sur, de la que documentamos 19 m de su longitud, presenta una anchura de 2,58 $\mathrm{m}$ y no se han documentado elementos hidráulicos de relevancia.

En el SECTOR 2 (Casas del Naranjal) el período medieval islámico está representado por una única fase fundacional de época califal, y varias subfases de reformas que indican de nuevo la continua evolución del arrabal
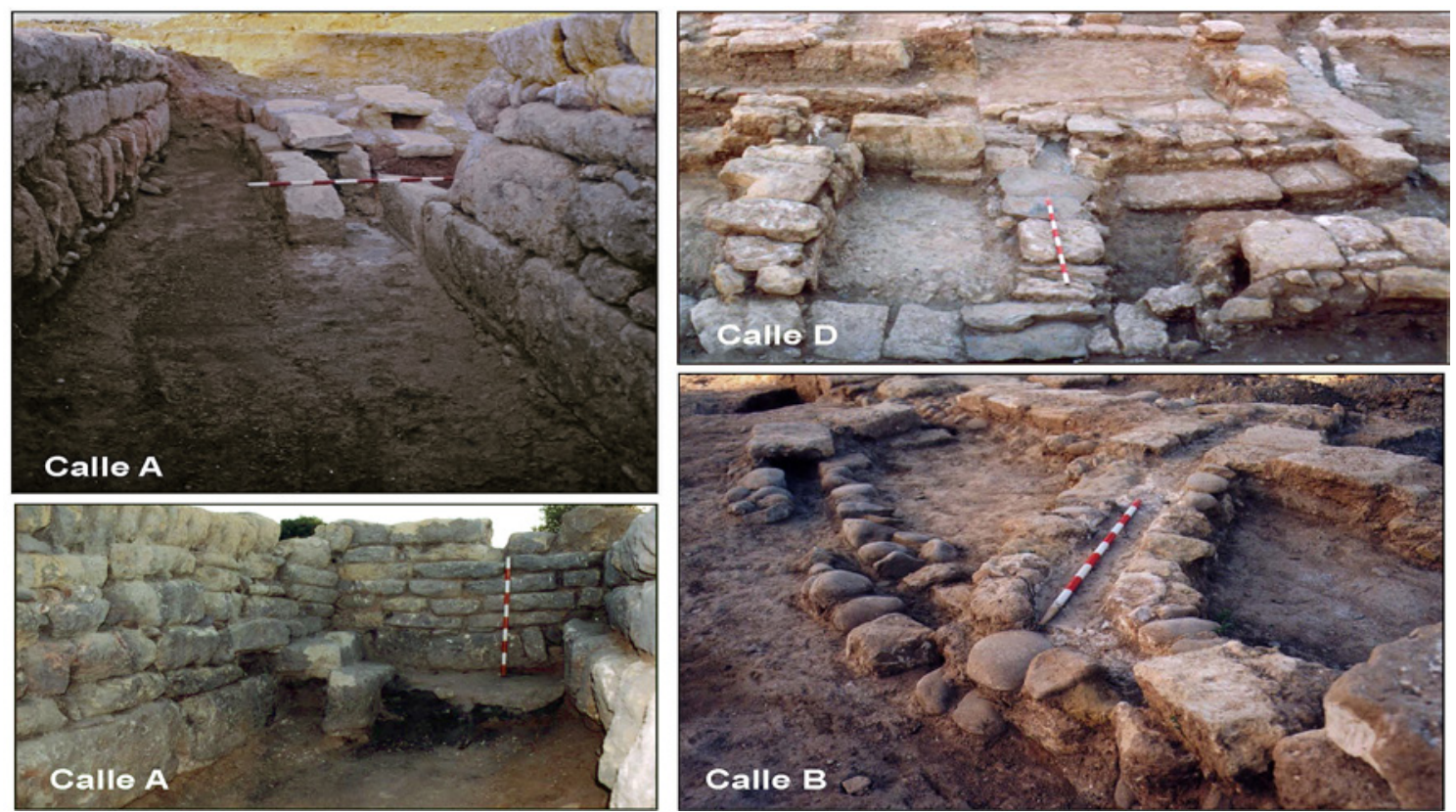

Lám. 5. Viario Sector 1. a) Calle A (desde el este). Dispositivos hidráulicos. b) Calle D (desde el este). Dispositivos hidráulicos. c) Calle A (desde el oeste). Cierre e Invasión espacio público. d) Calle B (desde el norte). Dispositivos hidráulicos. 
documentado. Se trata de una trama urbana compuesta por 7 calles (Lámina 12). Su prolongación hacia el norte, sury oeste, fuera del área intervenida, parece incuestionable. Por el contrario, dicho espacio urbano está perfectamente delimitado al este; la crujía trasera de las viviendas de la manzana más oriental sirve de límite al arrabal, encontrándonos, con toda probabilidad, en una zona de huertas vinculada a éste.

En este caso, las calles son más estrechas, oscilan entre 1,90 y 3,10 m. Se trata de dos grandes vías norte-sur, B y $\mathrm{C}$, a las que confluyen otras cinco en sentido este-oeste, A, D, E, F y G, que articulan 6 manzanas de trazado ortogonal, que contienen un total de 45 unidades domésticas (33 casas completas - legibles en toda su planimetría y algunos restos pertenecientes a otras 12 , excavadas sólo de forma parcial). En 6 de ellas se producen reformas de carácter estructural y en 9, de carácter puntual (Láminas 2 y 6).

Las relaciones estratigráficas indican que las primeras viviendas edificadas fueron las más orientales, articuladas por la Calle C, vía principal desde la que se accedería al Camino Nuevo de Almodóvar. La Calle C presenta una longitud excavada de 95,5 m y una anchura variable desde 2,50 m a 3,10 m. Las Calles A, $D$, F y G, de igual longitud, oscilan entre 1,90 y 2,30 m. La constitución de estas primeras manzanas denota su posible origen en formas geométricas derivadas del trabajo agrícola. Las viviendas de mayor tamaño, como la 12 y 13 , son las más cercanas al viario principal. Los vertidos de las viviendas son recogidos por atarjeas en las calles secundarias y desde éstas se conducen a la atarjea de la Calle principal. Los dispositivos hidráulicos se disponen en planta según las preferencias de cada vecino y en las dos viviendas mencionadas contamos como elementos excepcionales con un aljibe y una pileta.

En un momento indeterminado se construye un segundo eje viario principal, Calle B, y otro secundario, Calle E. La Calle B, con una longitud excavada de 56 m y una anchura variable entre 2,80 m y 3 m, presenta en su trazado más meridional un vano que junto a posibles vanos en calles perpendiculares (como vemos en el Sector 3) cerraría en las horas nocturnas
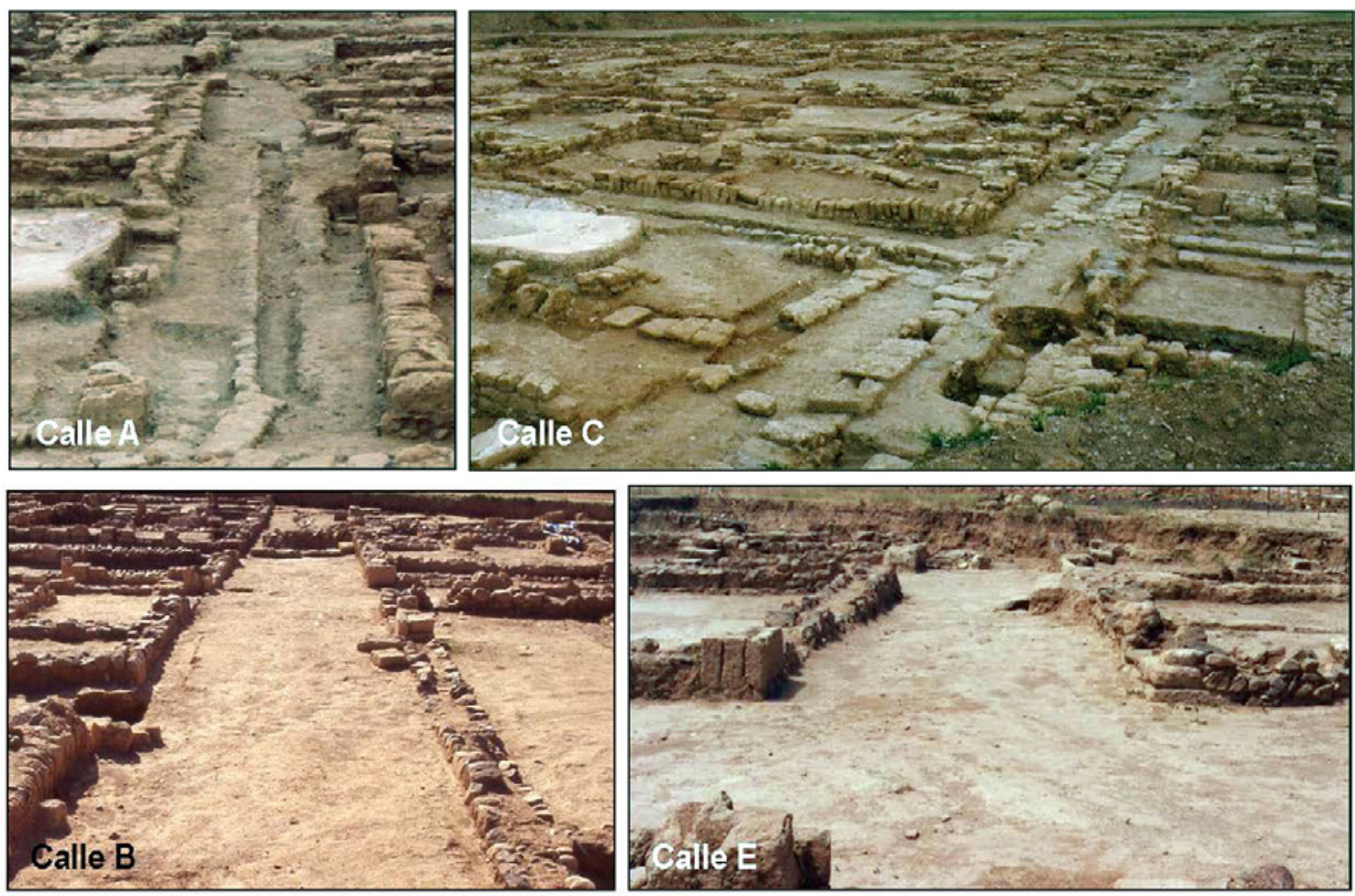

Lám.6. Viario Sector 2. a) Calle A (desde el este). b) Calle C (desde el sur). d) Calle B (desde el norte) e) calle $E$ (desde el este). 
para mantener la seguridad de los habitantes de esta área. La Calle E, con una longitud excavada de $14 \mathrm{~m}$, presenta una anchura variable entre 2,10 m y 2,30 m. En estas manzanas la edilicia de las viviendas es diferente, y los dispositivos hidráulicos más sencillos, reduciéndose en algunos tramos a la presencia de pozos negros en la línea de fachada.

En el SECTOR 3, a la fase califal fundacional pertenecen la totalidad de las estructuras domésticas documentadas correspondientes a sectores más o menos densos de un arrabal, articulado por 20 calles y dos caminos principales de acceso a la ciudad -Camino de las Abejorreras y Camino Viejo de Almodóvar-, que contiene 79 casas completas o legibles en toda su planimetría y restos pertenecientes a otras 58, excavadas sólo de forma parcial, es decir un total de 137. En el área de habitación ha sido posible determinar la existencia de una serie de reformas de carácter estructural en 8 viviendas y de carácter puntual en 32.
Junto a estas estructuras domésticas documentamos dos importantes áreas cementeriales, y un nuevo gran edificio residencial también ordenado en grandes crujías paralelas distribuidas en torno a grandes patios y corredores que, en este caso, es de fundación califal. Aunque ambos espacios, arrabal y cementerio, funcionaron sincrónicamente, la lectura de la secuencia estratigráfica indica que las primeras viviendas fueron las situadas junto a los caminos y en torno a la más meridional de las áreas cementeriales, donde constatamos varios niveles de enterramiento que indican mayor dilación temporal. El inicio de la función cementerial se produce, así, junto al Camino de las Abejorreras, y se desarrolla de sur a norte. Su creación (con 1455 inhumaciones) respondería también a una posible donación de habices teniendo en cuenta las estructuras hidráulicas que se ven amortizadas por las fosas.

El trazado ortogonal que define este viario se articula en tres niveles de planificación. En
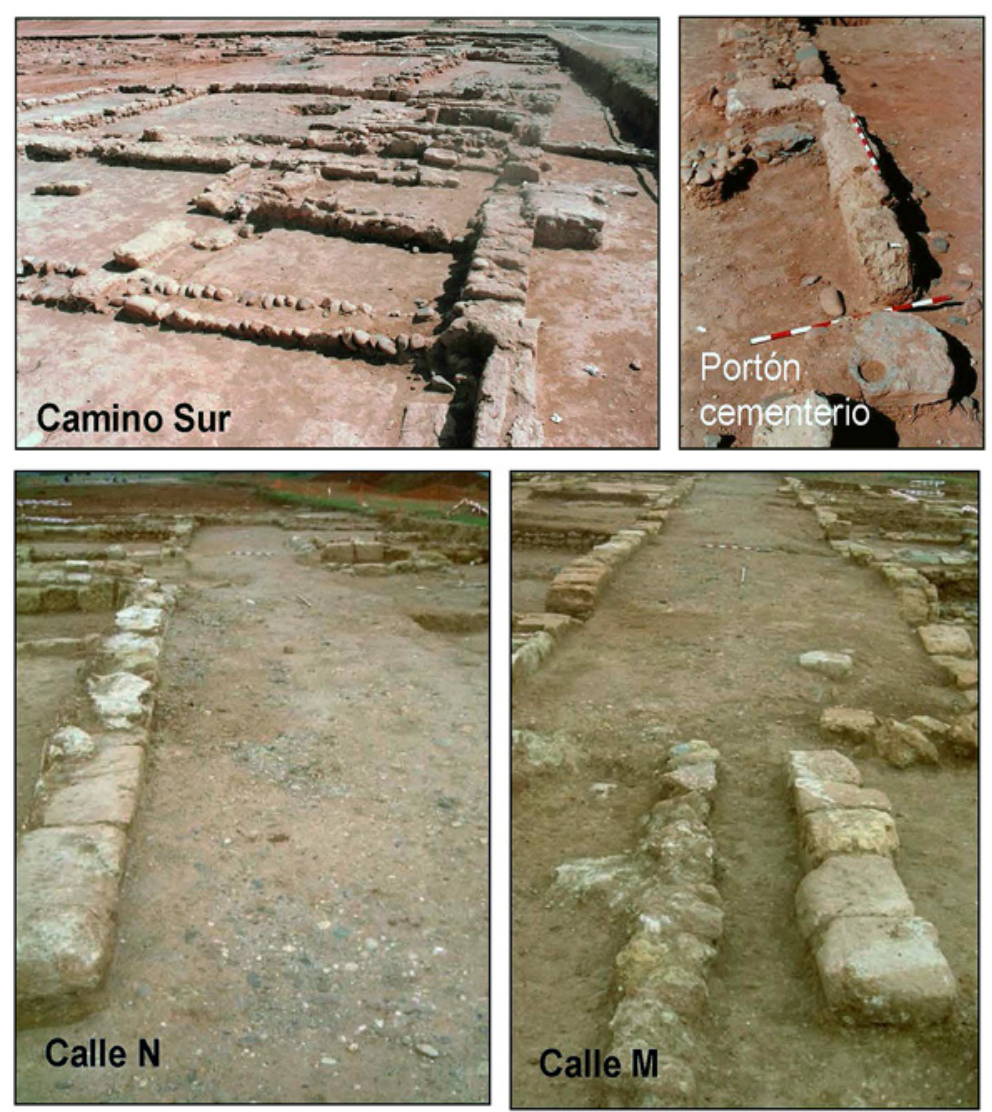

Lám.7. Viario Sector 3B-meridional. a) Camino Sur (desde el oeste). b) Portón de acceso al cementerio. c) Camino de las Abejorreras (desde el oeste). d) Calle N (desde el norte). e) Calle M (desde el este). f) Calle N (desde el sur). 
primer lugar, se observa una ordenación inicial respecto al viario principal este-oeste y a los elementos asociados a éste, cementerios y grandes propiedades agrícolas. A priori, este SECTOR 3 se encuentra dividido en dos por el Camino Viejo de Almodóvar, fosilizado en una vía de acceso contemporánea. La mayor densidad se concentra en el sector septentrional, que denominamos $3 \mathrm{~A}$, siendo el poblamiento menos denso en el sector meridional, 3B.

El sector meridional 3B, en el que se alternan las áreas de viviendas, de huerta y de cementerio, se articula mediante seis caminos secundarios o vías principales paralelas al viario principal, es decir, de trazado este-oeste, a las que confluyen otras tres vías secundarias de trazado norte-sur (Láminas 3, 7 y 14).

De sur a norte, la primera de las vías principales documentadas es la denominada Camino Sur. Dicho camino articula dos manzanas de viviendas, unidas por una estructura muraria que contiene un portón de acceso (de 2,90 m de ancho) al área cementerial sur. Desde este portón parten dos calles en abanico en torno a las que se distribuyen las inhumaciones, evidenciándose así a pequeña escala lo que a gran escala es modelo urbanístico de la zona.

La segunda de las vías principales documentadas es el denominado Camino de las Abejorreras, vía de acceso a la maqbara norte. En este caso articula tres manzanas de viviendas, dos abren al propio Camino y una tercera, de espaldas a la maqbara sur, abre a una calle paralela a éste, Calle O, con acceso desde otra perpendicular al mismo, Calle Ñ. La Calle O presenta una longitud excavada de 48,60 m y una anchura variable entre $4,15 \mathrm{~m}$ y 4,50 $\mathrm{m}$. Junto a realineaciones en los muros de fachada, documentamos diferentes niveles de pavimentación, así como diferentes fases constructivas para los dispositivos hidráulicos asociadas a reformas estructurales en algunos de los núcleos domésticos identificados. La Calle $\tilde{N}$, de 13,70 m de longitud y 2,50 m de anchura, abre en su frente occidental a una pequeña plaza presidida por un área pavimentada de grandes losas de arenisca, y ocupada por una estructura cuadrangular definida por cuatro pilares ochavados que pudiera corresponderse con un pequeño oratorio al aire libre.

La tercera de las vías principales documentadas es el denominado Camino Norte. En este caso articula de nuevo tres manzanas de viviendas, dos de ellas abren al propio Camino y una tercera, de espaldas a la primera de las áreas de huerta documentadas, abre a una calle paralela a éste, Calle $M$, con acceso desde otra perpendicular al mismo, Calle N. La Calle M presenta una longitud excavada de $41 \mathrm{~m}$ y una anchura entre 3 y $3,10 \mathrm{~m}$, y la Calle N, por su parte, 21,10 m de longitud y una anchura entre 2 y 2,20 m. Este espacio urbano parece generado en una única fase constructiva. La introducción de la red de evacuación de aguas se inició con el levantamiento de las canalizaciones principales o primarias encargadas de recoger las aguas procedentes de los canalillos secundarios que atravesaban las viviendas. La distribución en batería de las situadas más al norte y su alineación respecto a la alberca que preside el área agrícola situada más al norte, parece indicar que se trataría de un original diseño en lotes sobre terrenos yermos, previamente irrigados.

El último de los núcleos de este sector 3B es el situado al sur del Camino Viejo de Almodóvar. En este caso, la vía principal paralela a dicho camino, Calle K, articula de nuevo tres manzanas de viviendas, una al norte y dos al sur, separadas por la Calle L y de espaldas a la primera de las áreas de huerta documentadas. La Calle K presenta una longitud excavada de 44,70 m y una anchura variable de 2,25 $\mathrm{m}$ en su desarrollo hacia el este desde la Calle L, y 3,50 m en su desarrollo occidental. La Calle L, de 20,40 m de longitud y trazado irregular, presenta una anchura variable entre $2 \mathrm{~m}$ y 2,20 m. Las evidencias de uso agrícola previo se manifiestan en la concentración de estructuras hidráulicas -alberca, pozos noria y canalizaciones de atanores ensamblados-, reutilizados y/o amortizados en la trama viaria y doméstica (Lámina 8). 

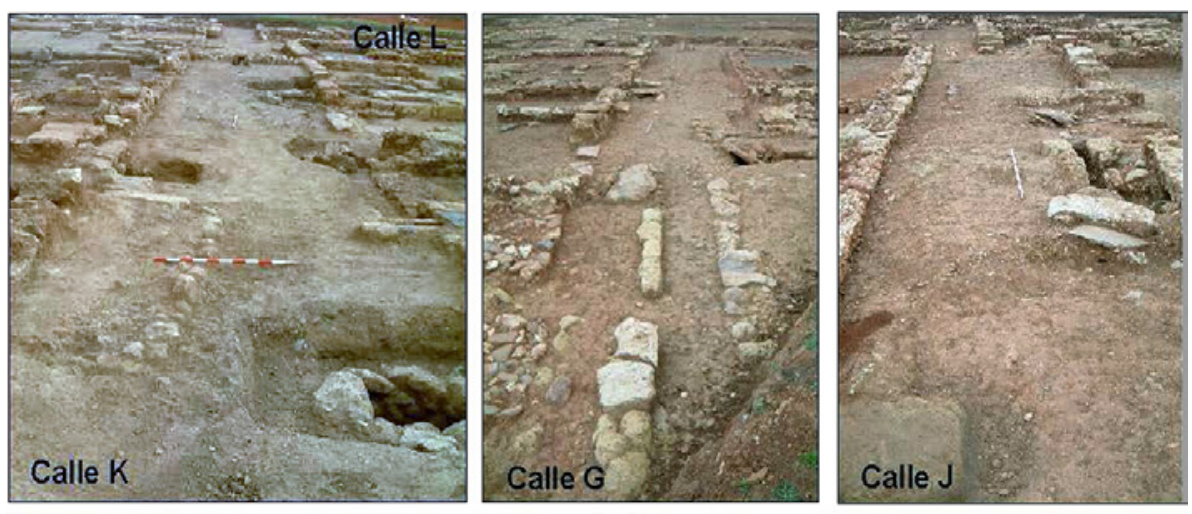

Lám. 8. a) Calle

K(desde el oeste).

b) Calle G (desde

el sur). c) Calle J

(desde el este).

Invasión espacio

público. d) Calle

L (desde el norte).

e) Calle I (desde el

sur).
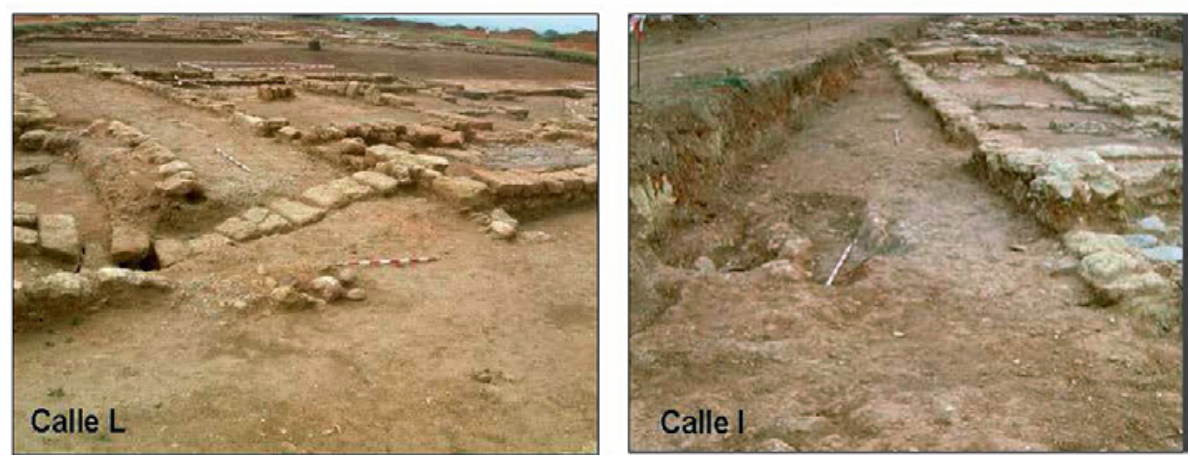

El sector 3A, al norte del Camino Viejo de Almodóvar, se articula mediante vías principales paralelas o perpendiculares al viario principal, a las que confluyen diferentes vías secundarias. El resultado en este caso es un caserío de gran densidad urbana, con un único vacío edificativo al sur del gran edificio residencial (Lámina 13).

Definimos dieciocho manzanas de viviendas de trazado ortogonal, organizadas en torno a catorce calles cuya anchura oscila entre 6 y 1,10 metros. La distribución espacial de las manzanas deriva de su articulación respecto a grandes ejes de trazado esteoeste y norte-sur en conexión progresiva con el viario procedente de la Medina. De sur a norte, contamos con los siguientes ejes: eje este-oeste Calle $\mathrm{H}$, al que confluyen las Calles I y G; eje norte-sur Calle $F=R$, al que confluyen las Calles P, T, S y Q; eje norte-sur Calle A, al que confluyen las Calles B, C, D y E. La lectura de la secuencia estratigráfica de cada uno de los ejes mencionados, la documentación de las diferentes unidades de pavimentación -de gravas, cantos, losas e incluso lajas de pizarra-, de diferentes sistemas de saneamiento, y el análisis individualizado de cada una de las unidades domésticas documentadas, evidencian diferentes procesos de génesis urbanística (Lámina 9).

Cada eje viario responde a uno o varios procesos evolutivos. El Eje articulado por la Calle $\mathrm{H}$, de entre 4,90 y 5,10 m de anchura, concentra un mayor número de viviendas de gran tamaño dada su cercanía al viario principal. En este caso, el tejido urbano crece por yuxtaposición, de sur a norte, definiendo nuevos ejes viarios de este a oeste (Calles J y P (9)), y de norte a sur (Calles I y G). Las viviend ${ }^{9}$ al sur de la Calle H, es decir, al norte del Camino Viejo de Almodóvar, generarían una primera manzana. Frente a este primer posible núcleo se edifican progresivamente diferentes manzanas de viviendas muy regulares. En la inmediata, quizá debida a una inicial parcelación agraria, subsiste un amplio jardín al norte de la vivienda 49.

\footnotetext{
9 Bajo la Calle P, Vázquez $(2016,280)$ nos advierte de la presencia de un arroyuelo estacional, canalizado mediante una estructura de cajones de losas de calcarenita sorteado en la propia Calle F mediante un pequeño puentecillo, también de losas de calcarenita, de 2 metros de ancho.
} 

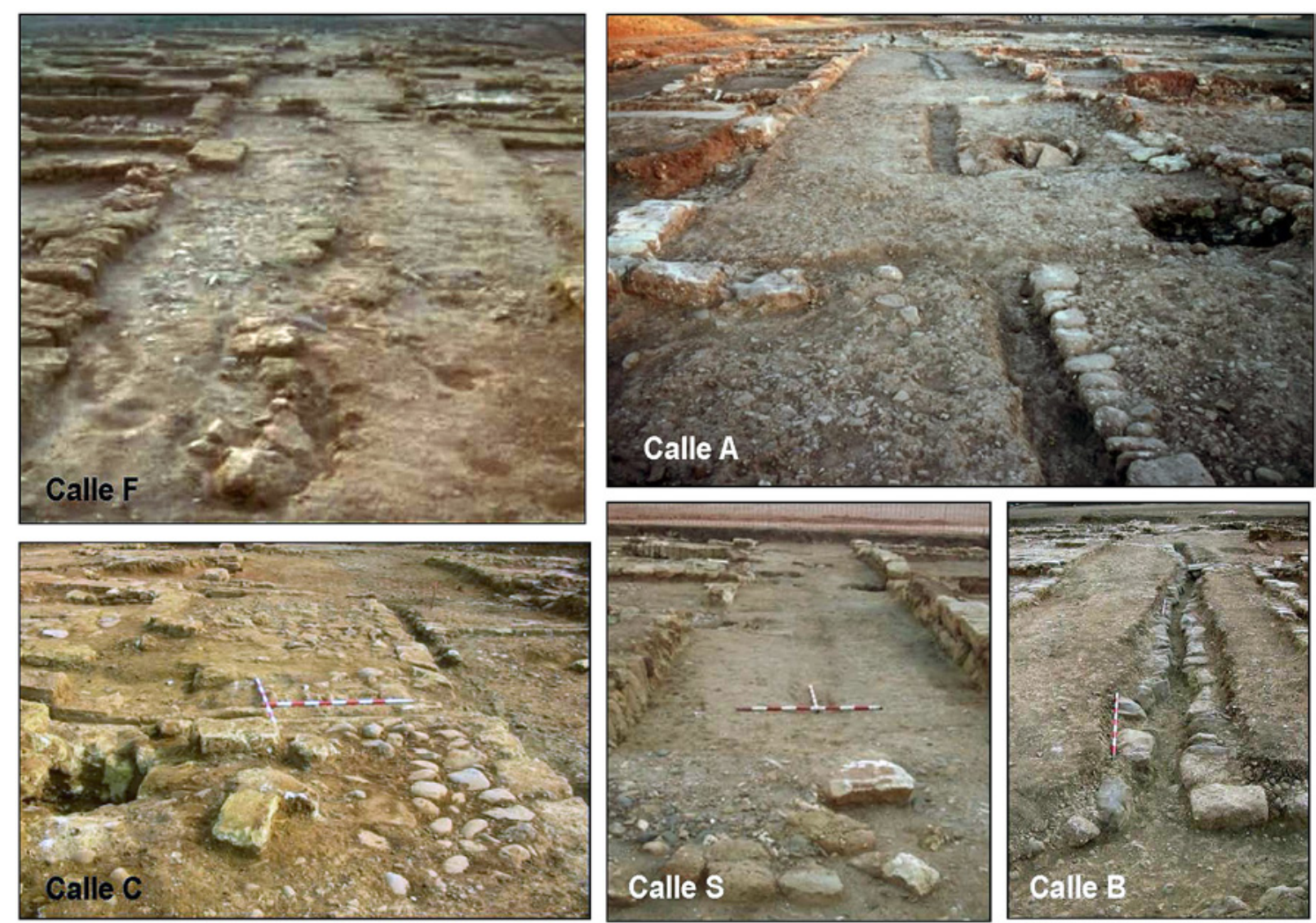

Lám. 9. Viario Sector 3A-septentrional. a) Calle F (desde el sur). b) Calle A (desde el sur). c) Calle C (desde el este). d) Calle $S$ (desde el oeste). e) Calle B (desde el oeste).

El Eje articulado por la Calle $\mathrm{F}=\mathrm{R}$, de entre 3,15 y 3,45 m, evidencia una posible expansión constructiva sobre formas geométricas derivadas de usos agrícolas. El resultado es un parcelario más o menos ordenado en manzanas muy regulares de viviendas homogéneas en batería (Calles Q y S) o en manzanas regulares cuyo interior se verá progresivamente edificado, dando como resultado un tipo de vivienda de planta irregular cuyo zaguán de entrada se define como callejón de acceso (Calles F=R y $\mathrm{T}$ ).

El Eje articulado por la Calle $\mathrm{A}$, de entre 4,40 y $5 \mathrm{~m}$, al que confluyen las Calles B, C, $D$ y $E$, aúna los procesos anteriormente mencionados. El trazado regular de las manzanas situadas más al norte evidencia un posible diseño sobre formas agrícolas. El interior de las manzanas va progresivamente edificán- dose, como lo indican nuevas viviendas con callejón de acceso como la número 16 (fachada a Calle A), al tiempo que se crean otras nuevas, hasta su conexión con las situadas más al sur. Las manzanas configuradas por las Calles C, D y E muestran cómo es el parcelario doméstico se adapta a un tejido urbano ya diseñado sobre formas agrarias precedentes. Este diseño se manifiesta en el bloque definido por las viviendas 20, 21, 22 y 24, esquina suroccidental de Calles Ay C, en las estructuras sobre las que se edifica el edificio-funduq no $30{ }^{10}$ y las viviendas adyacentes y, por último, en la clara adaptación al viario de las crujías meridionales de las viviendas con fachada a la Calle E.

La trama urbana del arrabal de fundación califal del SECTOR 4 (Carretera de Palma del Río) es, en este caso, sensiblemente inferior

10 Mientras en el caso de la Ronda Oeste la planta de estos fanadiq (edificios nos 23,25 y 30) es la que mantuvieron hasta la última fase de ocupación del arrabal, en otros ejemplos documentados en estos barrios occidentales, las crujías que rodean el patio se segregan con el paso de los años y quedan integradas en distintas viviendas, estado en el que han llegado hasta nosotros (CLAPÉS, 2014-2015, 248). 
en densidad a los sectores situados más al sur (Lám. 15). Se desarrolla al norte del Camino Viejo de Almodóvar ${ }^{11}$, se compone de 4 ejes viarios, 29 casas completas o legibles en toda su planimetría y algunos restos pertenecientes a otras 8 unidades domésticas excavadas sólo de forma parcial, y contiene un área industrial alfarera (Lámina 15). Dentro de esta fase ha sido posible determinar la existencia de una serie de reformas de carácter estructural en 7 viviendas y de carácter puntual en 2 de ellas.

Entre los ejes viarios principales que articulan el espacio urbano documentado, todos de desarrollo este-este, se incluye uno de los caminos principales de la ciudad, el conocido como Camino de la Matriz o Carril de los Toros. Cada eje articula cuatro áreas urbanísticas diferenciadas, aisladas entre sí, que contienen 6 manzanas de viviendas (Láminas 4 y 10).

La Calle A, la más meridional, de la que documentamos $41,17 \mathrm{~m}$ de longitud, presenta una anchura media de 3,05 m. Su edilicia más depurada -pavimentación, atarjea central y pozos negros- contrasta con las situadas más al norte, no así la configuración urbana que determina. Contiene la línea de fachada de las siete viviendas exhumadas en esta manzana, viviendas que quedan así de espaldas a la primera de las áreas agrícolas documentadas, sobre la que se sitúan. La estratigrafía muestra que la introducción de la red de evacuación de aguas se inició con el levantamiento de la atarjea principal, a la que se entregan los canalillos secundarios que recogen las aguas residuales de las casas. Éstos atraviesan las viviendas sobre los cimientos de las fachadas, lo que indica que fueron tenidos en cuenta en el diseño original de las mismas. De la misma manera, en éste como en otros casos ya indi- cados, la distribución de los pozos de agua en líneas paralelas a los muros de fachada parece indicar su realización "en cadena" en el momento de edificación de las manzanas, evidenciando de nuevo su surgimiento como fruto de la decisión de un gran propietario de tierras de urbanizar su propiedad.

La Calle B, de la que documentamos 48,90 $m$ de longitud, presenta una anchura media de 2,60 m. Define dos manzanas de viviendas, ocho exhumadas al norte y diez exhumadas al sur. En este caso, la realineación de la fachada entre algunas viviendas -nos 5 a 8 y 12 a 13 , al norte; y nos 1 a 2 y 26 a 30, al sur-, indica su edificación en lotes en diferentes fases constructivas. En este caso, la urbanización es muy precaria. No hay indicios de pavimentación, no documentamos atarjea central y sí pozos negros de diferentes etapas, cegados y amortizados sucesivamente.

Las viviendas se sitúan de espaldas a sendas áreas agrícolas; la más septentrional contiene una gran acequia subterránea de las escasas que hallamos dispersas en los alrededores de Córdoba y que formaría parte de la infraestructura hidráulica de alguna de las numerosas huertas, jardines y almunias que rodeaban la ciudad ${ }^{12}$, que además de norias y pozos, también se sirvieron de estos canales para el riego y para el consumo humano. Dichas conducciones, originadas en una fuente natural (en este caso posiblemente del arroyo Cantarranas), podrían alimentar a otras tantas fuentes que, con la expansión de la ciudad, quedarían insertas en el entramado urbano ${ }^{13}$. De una forma u otra, esta dotación de agua sería una nueva infraestructura, complementaria de aquellos baños, mezquitas y cementerios que, costeados por ricos

11 Junto a éste (antigua Via Cordoba-Hispalis) documentamos en este sector parte de la necrópolis occidental de la ciudad, con una cronología de entre los siglos III y IV d.C. (CAMACHO, 2004).

12 Las fuentes escritas elogian aquellos qanawāt construidos para abastecer las almunias que fueron propiedad de emires y califas como al-Rusafa y al- Nǟüra. Los escasos tramos de qanawät periurbanos que se han excavado en Qurtuba, inconexos, apenas permiten distinguir qué propiedad regaban sus aguas, más cuando el derecho islámico contempla la servidumbre de paso de una conducción a través de la finca de un tercero (PIZARRO, 2012, 180).

13 Según al-Mawardi y otros juristas las aguas públicas procedentes de un arroyo pasaban a ser de propiedad privada cuando alguien las canalizaba y las empleaba en regar una tierra muerta. Una vez que el agua llegaba a su destino se convertía en propiedad privada: esto debió favorecer la construcción de qanawāt financiados bien por los propietarios de las tierras que habían de regarse, bien por las comunidades de campesinos que las trabajaban. Ahora bien, los excedentes de dicha agua deben donarse a aquél que los necesite para beber (PIZARRO, 2012, 179; VIDAL, 2008, 164-165). 
personajes, impulsarían la urbanización de determinadas zonas periurbanas como en la que nos encontramos. La adscripción de esta acequia a la gran residencia localizada en el Sector 3 sería una opción, aún por confirmar arqueológicamente ${ }^{14}$.

Se trata de una canalización de gran magnitud y utilidad, cuya construcción debió requerir conocimientos técnicos especializados y, consecuentemente, el empleo de recursos económicos abundantes. La obra se inició excavando una zanja en el terreno geológico de 1,75 m de anchura y 2,20 m de profundidad máxima. Su fondo se regularizó con una capa de mortero de cal y arena mezclada con pequeños trozos de calcarenita. La base de la conducción es una plataforma de sillares dispuestos a tizón, orientados en sentido perpendicular al trazado del canal y unidos con mortero. Su interior está impermeabilizado con mortero pintado a la almagra, y los ángulos del fondo sellados con sendas molduras del mismo material. Su specus es de unos $0,70 \mathrm{~m}$ de alto y su anchura de $0,46 \mathrm{~m}$. Documentamos además un pozo de registro, de sección cuadrada. Su fondo estaba a mayor profundidad que el resto del trazado para que en él se decantasen las impurezas del agua.

A su zona norte vierten dos canalizaciones de menor tamaño. La más occidental transcurre de norte a sur, con una orientación de $190^{\circ}$ SO, y una longitud total de 22,70 metros de largo. Está construida con sillares de caliza dispuestos a soga en posición horizontal, en la base, a soga en posición vertical en las paredes, y en la cubierta, colocados en posición vertical, en sentido transversal a las paredes. Su altura total desde la base a la cubierta es de 1,25 metros. El interior, por donde transcurría el agua, tiene una profundidad de 0,60 metros y una anchura de 0,36 metros. Este canal secundario se inicia desde un registro, con los lados irregulares: el interior mide 0,58 $\mathrm{m}$ al norte, 0,44 $\mathrm{m}$ al este, 0,64 $\mathrm{m}$ al sur y 0,60 $\mathrm{m}$ al oeste. En su interior, en las labores de limpieza, se documentó un estrato compuesto por un nivel de 15 a $20 \mathrm{~cm}$ aproximadamente de greda, sin resto cerámico alguno, sedimentación favorecida por la poca pendiente de desagüe del canal.

La canalización más oriental tiene un trayecto más corto y transcurre de norte a sur, con una orientación de $180^{\circ} \mathrm{SE}$, de gran pendiente. Está construida con sillares de caliza dispuestos a soga en posición horizontal, en la base, a soga en posición vertical en las paredes, y en la cubierta, colocados en posición vertical, en sentido transversal a las paredes. Su altura total desde la base a la cubierta es 0,90 metros. El agua transcurre por un canal de 0,36 metros de profundidad y 0,20 metros de anchura. No se documentó estrato alguno en los trabajos de limpieza, hecho favorecido por la gran pendiente.

Las tres conducciones estuvieron en uso durante un periodo de tiempo bastante breve, pues los materiales recuperados de la zanja de saqueo son de cronología tardoislámica ${ }^{15}$. Su abandono pudo deberse a varios factores combinados. La naturaleza de sus aguas pudo hacer que la conducción quedara inservible, completamente cegada por concreciones calcáreas y, siendo imposible su reparación, no se le encontró un mejor destino que el saqueo de sus sillares. O bien, una vez desaparecida durante la fitna la almunia a la que abastecía dejó de tener sentido mantenerla en buen estado.

La tercera área urbanística en este sector viene definida por la presencia del Camino de la Matriz o Carril de los Toros, de 7,30 m de ancho. La calzada presenta como pavimentación un empedrado consistente en una mezcla de cantos rodados y pequeñas piedras aristadas, totalmente uniformes entre sí, pero

14 Podría tratarse del mismo canal de la Huerta de Santa Isabel, exhumado más al oeste, que G. Pizarro asocia a Dar al-Naura (PIZARRO, 2012, 187-190).

15 El hecho no es nada frecuente pues en el periodo andalusí las infraestructuras relacionadas con el abastecimiento y almacenamiento de agua se mantuvieron en buen estado, bien mediante sucesivas reparaciones, bien mediante la derivación de su caudal hacia un nuevo destino (PIZARRO, 2012, 185). 
enmarcadas entre dos hileras de pequeñas pizarras, conservadas sólo en la zona más meridional. Junto al Camino se edifica una segunda mezquita de barrio y una manzana con diez viviendas exhumadas, de características edilicias muy similares a las de las manzanas situadas más al sur. En este caso, los vertidos se realizan desde los patios mediante canalillos a la vía y, desde las letrinas, a pozos negros situados junto a la línea de fachada.

La Calle D, de la que documentamos 16,38 $\mathrm{m}$ de longitud, presenta una anchura media de 2,90 m. También de trazado este-oeste, sin indicios de pavimentación ni atarjea central, y sí de pozos negros que recogen el vertido de las letrinas, define dos manzanas de viviendas. En la meridional documentamos las dependencias de habitación, trabajo y almacenamiento de un alfar, y dos viviendas; en la septentrional, una tercera vivienda.

Para el emplazamiento de las instalaciones artesanales, consideradas como fenómenos típicamente periurbanos, deben ser valorados una serie de factores físicos y económicos presentes en este sector, que deben hacer rentable y viable la inversión necesaria para el inicio de la actividad. Los factores físicos identificados son: abundancia de arcilla, existencia de un abastecimiento continuo y suficiente de agua y existencia de combustible necesario en el proceso de cocción. Los factores económicos son: orientación mercantil por su ubicación junto a vías públicas principales y especialización cerámica en objetos utilitarios ${ }^{16}$. En el
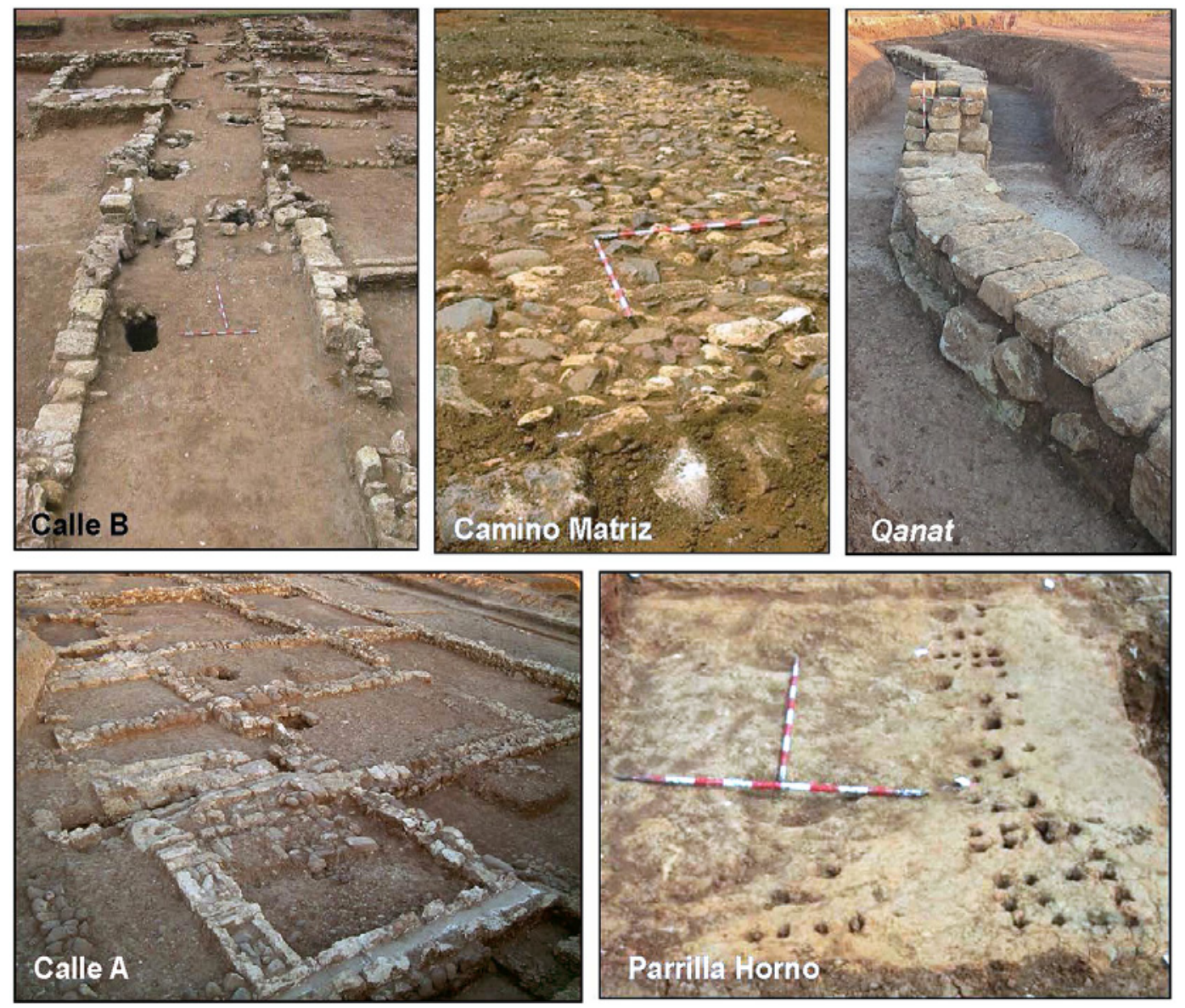

Lám. 10. Viario y estructuras Sector 4. a) Calle B (desde el oeste). b) Camino de la Matriz (desde el este). c) Acequia subterránea. d) Viviendas a Calle A (desde el este). e) Parrilla Horno 1.

16 La constatación de fallos de cocción y material in situ en la zona intervenida indican una cierta especialización en tipos cerámicos: material de construcción (tejas) y cerámica común no vidriada (piezas de gran tamaño, aunque de formas y capacidades diversas destinadas a la contención de líquidos y sólidos) (CAMACHO, 2004; SALINAS, 2012, 616-622). 
alfar documentamos tres hornos de planta rectangular de corredor central y tiro vertical, junto a distintas dependencias de trabajo y almacenamiento, así como zona de desechos y de secado.

\subsection{Fase final del califato. Fitna}

Cuando en el año 1009 se produce el colapso del Estado omeya, comienza un periodo de inestabilidad que se prolonga hasta el año 1031. El estallido de la fitna, momento en que se produce el saqueo de Madinat alZāhira y Madinnat al-Zahrā', también supone el arrasamiento y destrucción de los arrabales occidentales cordobeses (LEÓN MUÑOZ, LEÓN PASTOR y MURILLO, 2008, 275-276). El rápido y traumático abandono viene confirmado por la documentación de potentes niveles de incendio, depósitos de material cerámico en suelos de ocupación, el hallazgo de tres tesorillos ${ }^{17}$, y la presencia de pozos sellados por losas de pizarra al abandonar la vivienda, lo que parece indicar la esperanza de un regreso. A ello se unen los derrumbes de los tejados realizados con tejas sobre cañas, de los muros de zócalo y alzado de tapial de las viviendas, así como todos aquellos elementos en vertical, son cortados por una única interfacies de destrucción.

\section{EL ESPACIO AGRÍCOLA}

El punto de partida para debatir sobre el parcelario doméstico de los arrabales de Qurtuba es la Medina, pues es el desbordamiento de ésta la génesis del mismo.
Cuando en octubre del 711 la antigua Colonia Patricia Corduba es ocupada por Mugit, la ciudad a la que llegan los conquistadores islámicos es una ciudad amurallada y ya, desde el siglo IV, saturada y desbordada. Tras la etapa de los gobernadores del califa, dependientes del califato omeya de Oriente, caracterizada por la ausencia de un programa de directrices claras en la articulación de la ciudad y de su territorio, el acceso al poder de 'Abd al-Ramān I supondrá el inicio de la islamización de la topografía urbana. Al nuevo emir se debe, junto a la fundación de la mezquita aljama y la creación de la infraestructura básica del Estado, la consciente articulación del espacio periurbano con la construcción de grandes almunias exteriores al perímetro urbano, que va a caracterizar la imagen física de la ciudad como una urbe abierta (ACIÉN y VALLEJO, 1998, 114).

La labor iniciada por 'Abd al-Ramān I, continuará con Hišām I, al-Hakam I y 'Abd al-Ramān II, de forma que, los emires cordobeses, por si mismos o con el auxilio de su círculo familiary gubernamental, comienzan a dotar a la periferia de Qurtuba de una incipiente ordenación urbanística, garantizando al mismo tiempo la explotación agrícola y ganadera del territorio próximo a la ciudad con el fin de asegurar su propio abastecimiento (MURILLO, CASAL y CASTRO, 2004, 266).

Este espacio periurbano, de gran riqueza agrícola, se sitúa jurídicamente en el territorio de influencia inmediata de la ciudad, en una periferia rural de la que se abastecería ${ }^{18}$. Como

\footnotetext{
17 La mayoría de los hallazgos de época califal suelen presentar una cronología amplia, que abarca desde 'Abd al-Ramān III hasta la fitna. Aunque la localización de dos de ellos en niveles de incendio es un ejemplo más del momento de inestabilidad y violencia vivido durante la fitna, uno es de cronología anterior (al-Hakam II), por lo que resulta difícil una explicación arqueológica, por el momento, para este ocultamiento concreto, que debió producirse en el tercer tercio del siglo X y no parece estar vinculado con el periodo convulso del final del califato. Otro de los conjuntos es un grupo de monedas falsas preparadas para ser introducidas en un momento concreto. Dada su forma irregular parece imposible que estuviera dedicado a circular con las monedas salidas de la ceca, por lo que cabe la posibilidad que su fin último fuera el de ser utilizadas como moneda fragmentaria, una vez cortadas y plateadas (CANTO y CAMACHO, 2009).

18 Aun no siendo el tema que nos ocupa, en este contexto político-administrativo, entraría en debate la definición de las estructuras sobre las que se basó la propiedad de la tierra. Considerando como base de la organización administrativa andalusí el sistema fiscal, y éste como principal agente de la islamización del territorio, la probada conjunción entre expansión urbana e islamización deriva así de los diferentes estatutos fiscales aplicados (MARTAGÓN, 2009/2010, 304-311). Por un lado, la arqueología y las fuentes confirman que algunos grandes propietarios cristianos, incluida la iglesia mozárabe, retuvieron una parte significativa de sus antiguas posesiones hasta momentos relativamente avanzados del siglo IX. Por otro, confirman la progresiva sustitución de modelos de tributación directa por otras fórmulas de transferencia de riqueza al Estado y a la aristocracia árabe, fundamentadas en la generación de riqueza por parte de una población esencialmente musulmana y urbana (VAQUERIZO y MURILLO, 2010, 539).
} 
indica al-Razi, este espacio estaría sembrado de multitud de almunias y grandes huertas, y sería explotado mediante grandes y pequeñas propiedades agrarias intensivas (ARJONA, 1982, n. ${ }^{3}$ 312, 241-242). Los recursos obtenidos en ellas, materias primas, agua y productos alimentarios llegarían a la Medina a través de una red de caminos, heredados en su mayoría de la etapa romana, en torno a los que, junto a cementerios e instalaciones artesanales ${ }^{19}$, se desarrollarán los arrabales.

Como hemos visto, esta función agrícola previa queda de manifiesto en la presencia de estructuras hidráulicas precalifales (en SECTOR 1, 3 Y 4), pero también en la existencia de áreas residuales de explotación agrícola (en SECTOR 2, 3 y 4) y en la distribución de buena parte del parcelario analizado. Así, junto a procesos de crecimiento espontáneo en torno al viario principal, que posteriormente analizaremos, evidenciamos procesos de conversión de grandes, medianas y pequeñas propiedades rurales en áreas urbanas. Podríamos hablar pues, de particiones de posibles parcelas fundacionales difíciles de determinar.

Dado que la organización de los procesos de trabajo agrícola, requieren formas geométricas y limitadas, la expansión constructiva sobre propiedades rurales daría lugar a un parcelario más o menos ordenado, en manzanas muy regulares de viviendas homogéneas (Figura 3 y 4), muchas de ellas en batería (Figura 5). Como veremos más adelante, las manzanas irán jerarquizándose desde o hacia el viario principal y su interior se verá progresivamente edificado (GUTIÉRREZ LLORET, 2012, 159-160).

En el SECTOR 1 esta partición se refiere a fincas con construcciones de carácter residencial ${ }^{20}$. Constatamos así que algunas de las estructuras de una gran residencia de rasgos palatinos son amortizadas, pasando a formar parte del viario secundario y las viviendas de un sector de arrabal (Lámina 11).

En el resto de los sectores esta partición se refiere a simples huertos o áreas sin edificar. En el SECTOR 2 el parcelario está perfecta-

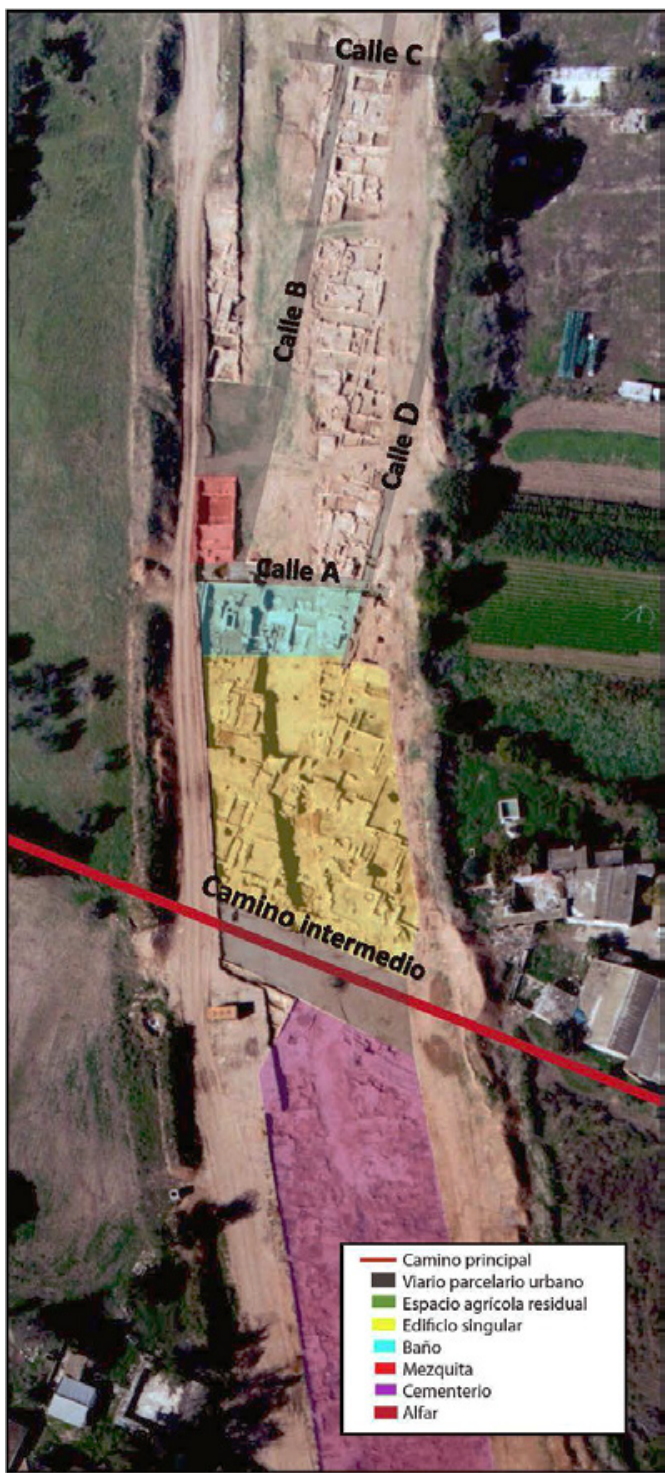

Lám. 11. Unidades espaciales Sector 1 Ronda Oeste de Córdoba.

19 Acién, 2001, 30-32 defiende el papel de la industria y del comercio en la aparición y desarrollo de la ciudad islámica. Analiza las numerosas evidencias de instalaciones artesanales y/o comerciales como focos de atracción urbana: en Sevilla, Almería, Málaga, Jaén, Pechina, Alicante, Denia o Valencia.

20 Procesos identificados en otras urbes como Murcia y Siyasa (NAVARRO y JIMÉNEZ, 2004, 362-363). 
mente delimitado al este, constituyendo la crujía trasera de las viviendas de la manzana más oriental el límite a una zona de huertas probablemente vinculada al mismo. La configuración de esta manzana, con viviendas en batería, y las anexas, generadas por la edificación de las Calles A, D, F y G de igual longitud, indica asimismo un posible origen en formas geométricas derivadas del trabajo agrícola (Lámina 12).

En el SECTOR 3 son tres las áreas residuales de explotación agrícola documentadas. Las situadas más al norte se sitúan al norte y sur del gran edificio residencial localizado. Como en el sector 2, las manzanas situadas al sur, distribuidas en sendos ejes de desarrollo norte-sur, articulados por las Calle $A$ y $F=R$, respectivamente, evidencian una posible expansión constructiva sobre formas geométricas derivadas de usos agrícolas. La más meridional contiene una alberca de 4,50 × 4 m, y como en el caso anterior, la distribución en batería de las viviendas situadas más al sur, articuladas por las Calles M y N, parece indicar que su ejecución se realiza tras su diseño original en lotes sobre terrenos yermos, previamente irrigados (Láminas 13 y 14).

En el caso del SECTOR 4, será la existencia de terrenos agrícolas, vinculados bien a la propiedad a la que abastece la gran acequia, bien a la mezquita de barrio existente, la que determine la excepcional distribución y densidad del parcelario documentado. Esta distribución se explica además por factores concurrentes como son la reconocida situación de la necrópolis tardoantigua, y la presencia de un área industrial de marcado carácter periurbano, necesitada de espacios libres de desarrollo (Lámina 15).

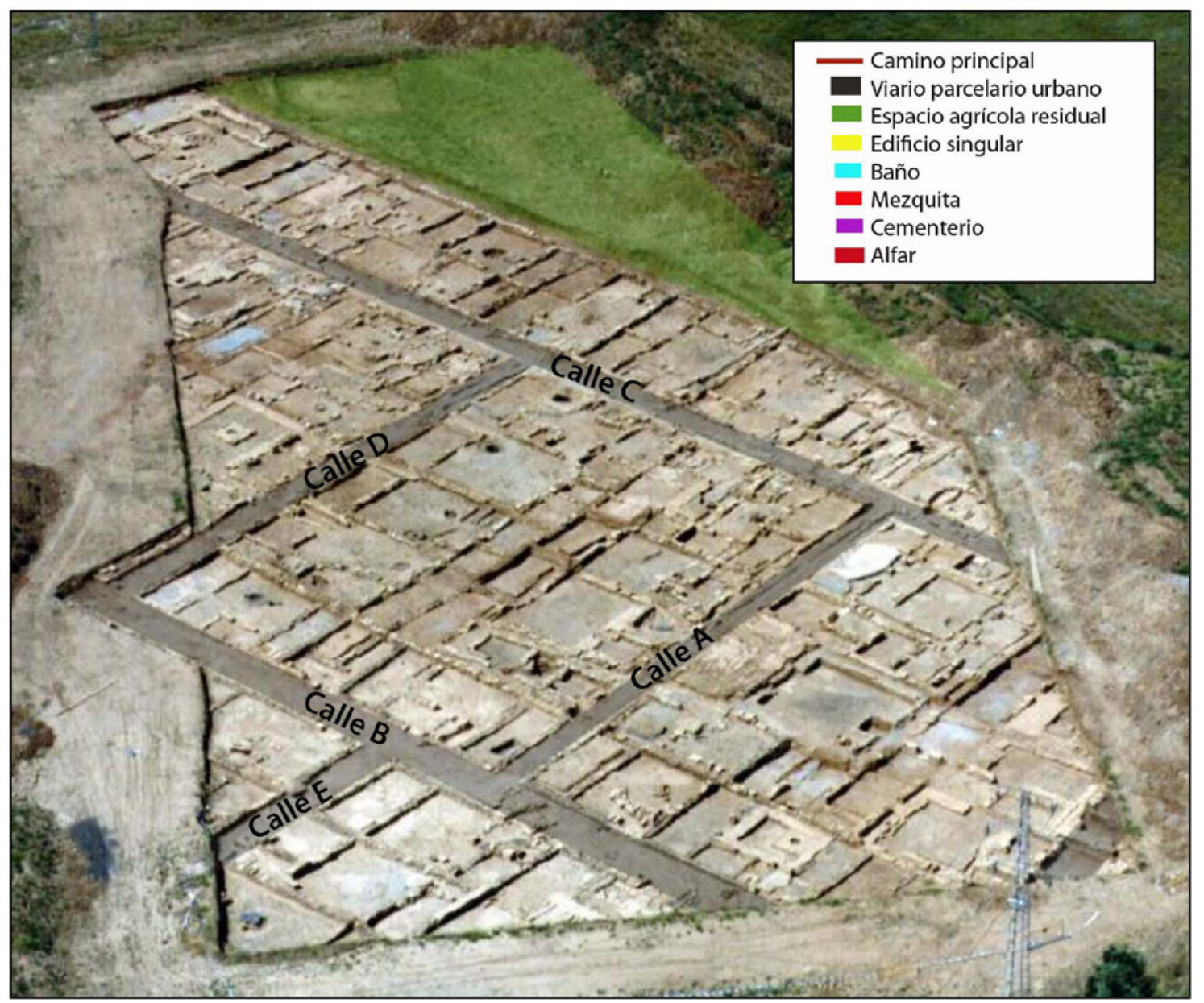

Lám. 12. Unidades espaciales Sector 2 Ronda Oeste de Córdoba. 

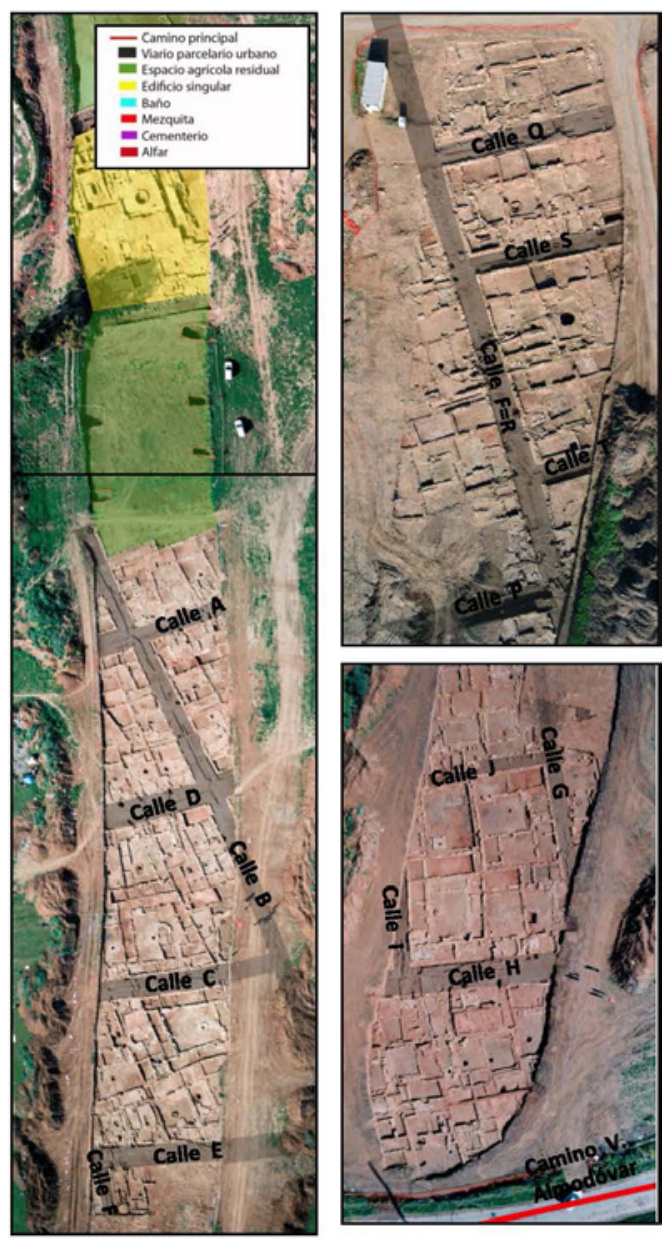

Lám. 13. Unidades

espaciales Sector $3 a$

Ronda Oeste de Cór-

doba.
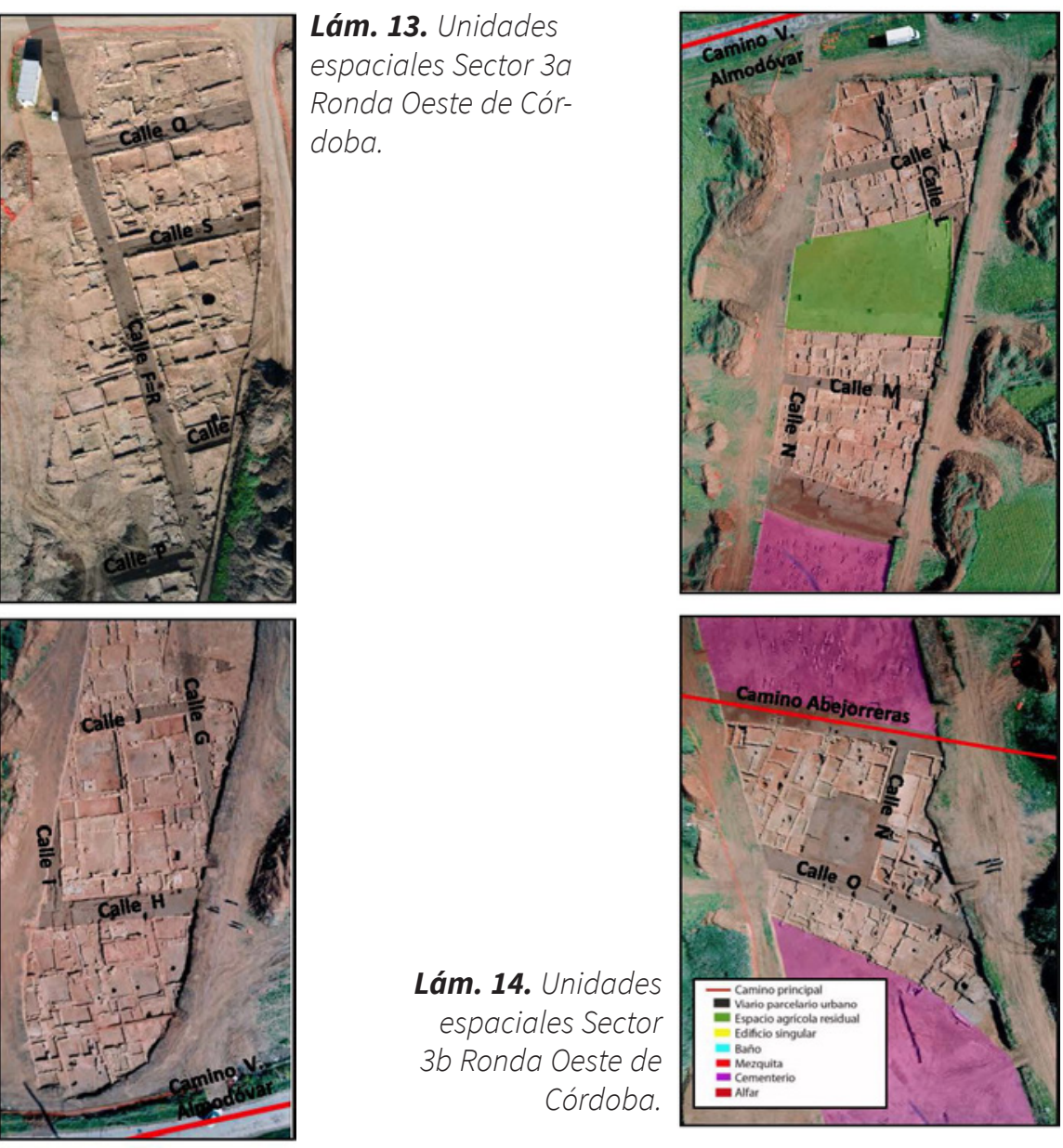

Lám. 14. Unidades espaciales Sector 3b Ronda Oeste de córdoba.

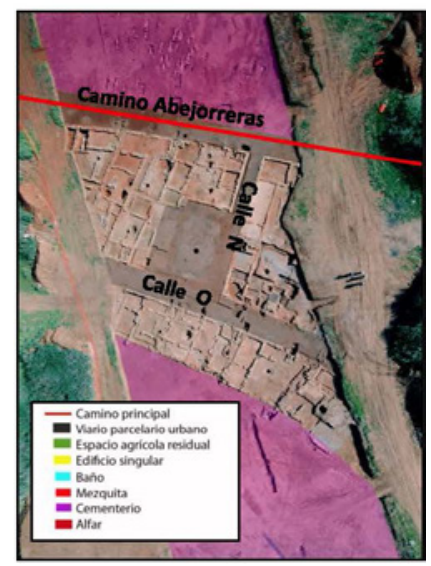

Lám. 15. Unidades espaciales Sector 4 Ronda Oeste de Córdoba.

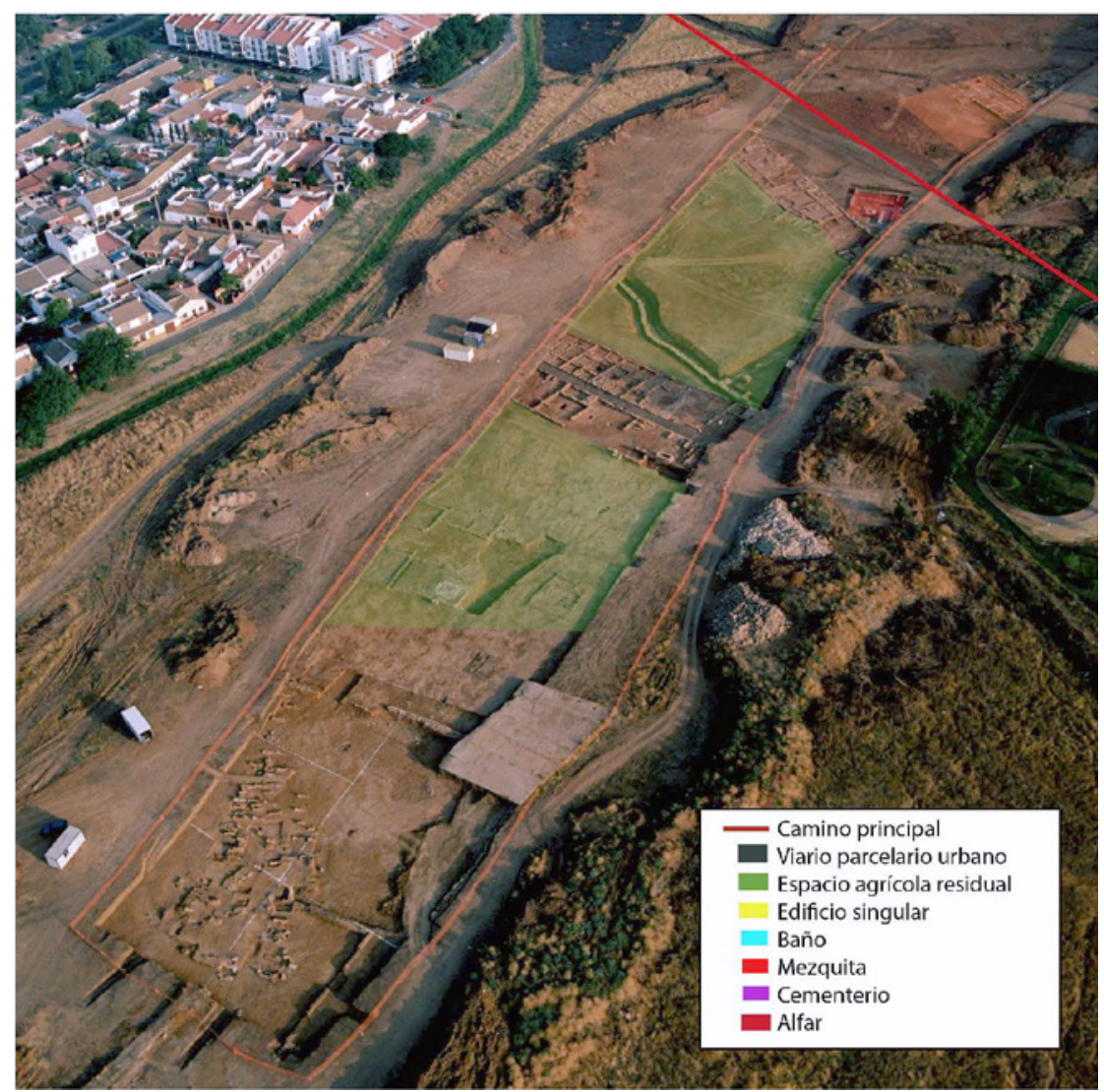



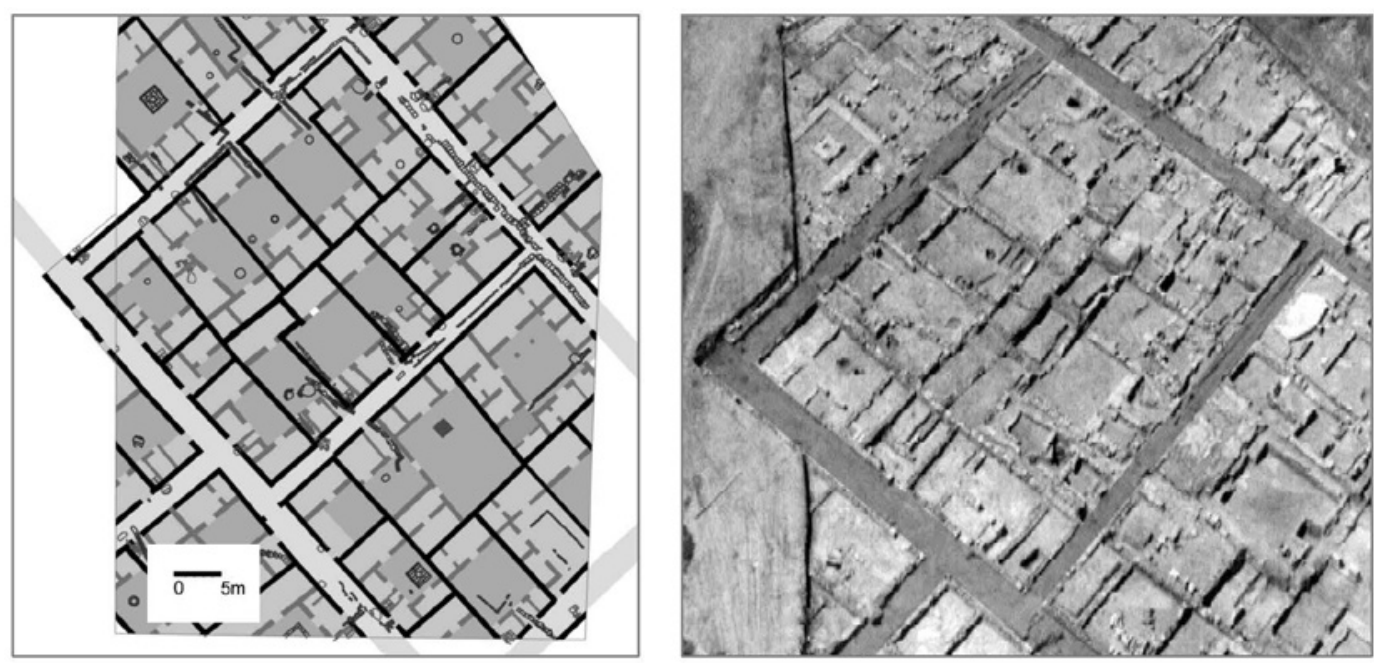

Fig. 3. Procesos de edificación sobre posibles parcelaciones agrarias. Sector 2.
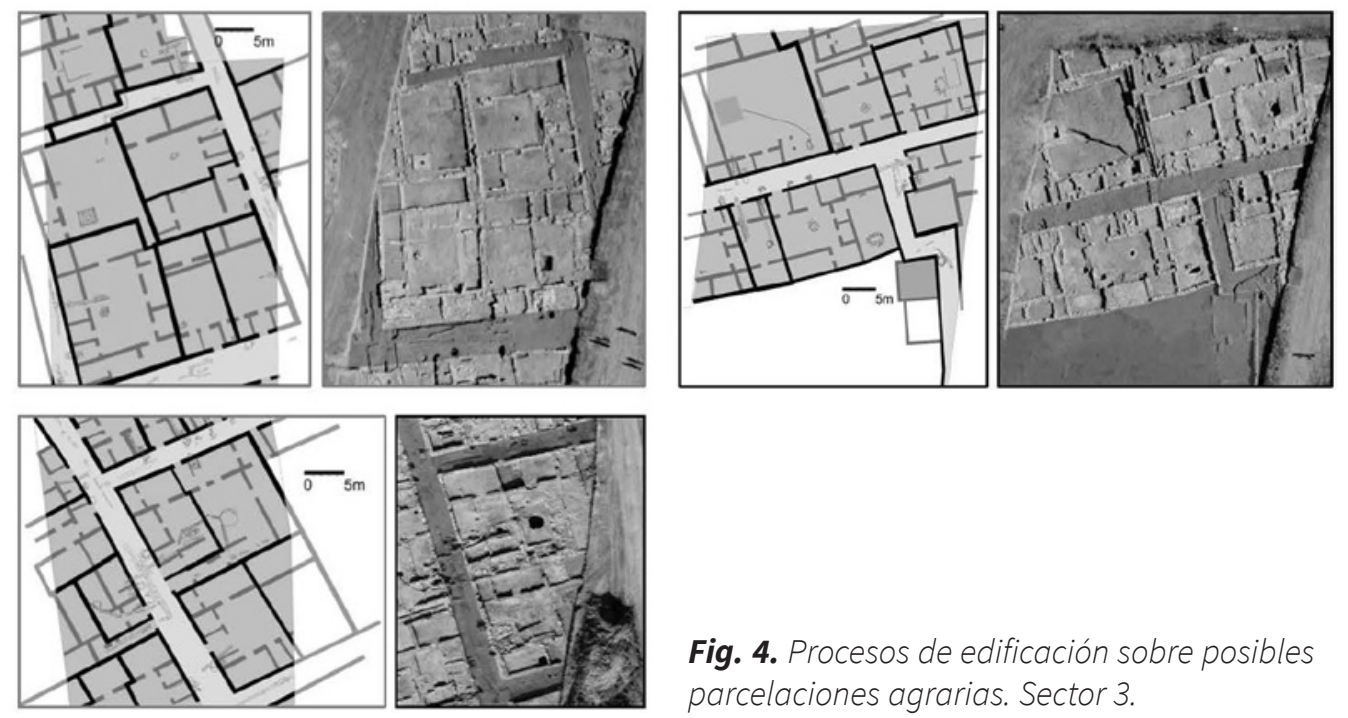

Fig. 4. Procesos de edificación sobre posibles parcelaciones agrarias. Sector 3.
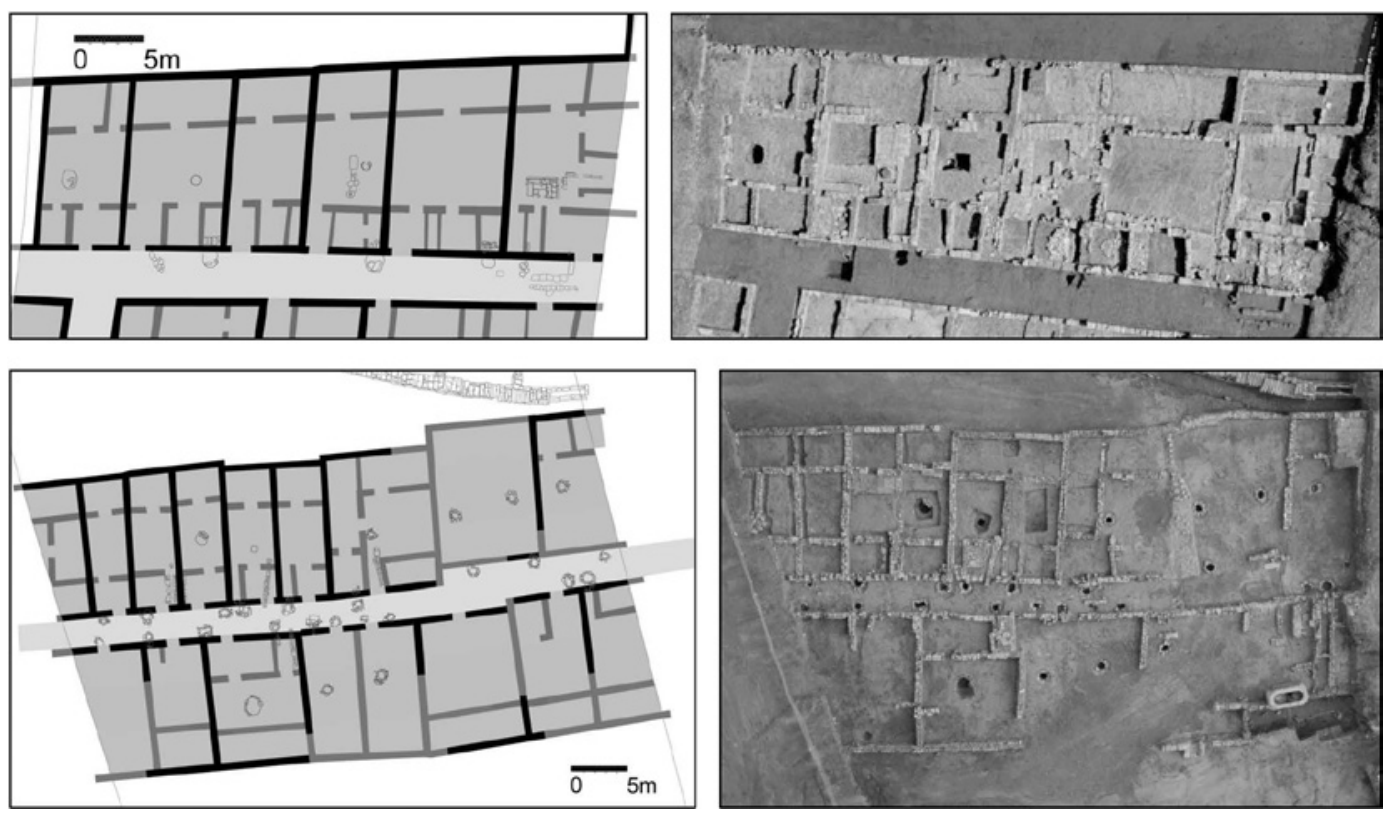

Fig. 5. Procesos edificación de viviendas en batería. Sector 3 y Sector 4. 


\subsection{Ubicación respecto al viario principal}

Como bien indica la secuencia estratigráfica, el paisaje de estos arrabales occidentales lo constituirían amplias extensiones de huerta y tierra de labor, en las que se ubicarían pequeños núcleos habitacionales que, con el progresivo incremento demográfico de la ciudad, irían haciéndose más numerosos, especialmente a lo largo de los principales caminos de conexión con la Medina, que poco a poco terminarán convirtiéndose en calles de un entramado urbano de gran densidad.

Son relativamente abundantes los datos sobre urbanismo islámico en Qurtuba, aportados por las fuentes literarias. De entre informaciones más o menos precisas, de crónicas históricas, libros de poesía, repertorios biográficos y/o obras de tipo jurídico y notarial, destacan los listados en repertorios biográficos de Ibn Baškuwāl (XII) e Ibn al-Jatib (XIV) llegados a nosotros gracias a al-Maqqari (XVI-XVII). Según estos autores, Qurtuba llegó a tener veintiún arrabales, a los que se llegaba a través de siete puertas dispuestas por todo el recinto de la Medina: dos hacia el Sur en la otra orilla del Guadalquivir ${ }^{21}$, siete hacia el Este ${ }^{22}$, tres hacia el Norte ${ }^{23}$ y nueve hacia el Oeste (ZANÓN, 1989).

Los nueve situados en este sector occidental, con acceso desde Bab al-Amir, Bab al- Yawz y Bab Isbiliya, se identifican, como en los casos anteriores, con nombres que se corresponderían con el de la almunia, mezquita o cementerio de época emiral en torno a los que se desarrollaron: Haguanitar-Raihan o arrabal de los perfumistas, en el barrio del Alcázar Viejo, inmediato a las puertas del Alcázar califal; Balāt Mugitt, en la Ilanura que actualmente ocupa el Zoológico Municipal (RUIZ LARA ET ALII, 2008); masŷid al-Šifä', que toma su nombre de la mezquita fundada por una de las concubinas favorita de 'Abd al-Ramān II, junto a la Ciudad Sanitaria en la zona conocida como Fontanar de Cabanos (LUNA y ZAMORANO, 1999); Hammām de al-Ilbīrī en el denominado Sector 1 de Ronda Oeste de Córdoba, junto a la antigua Facultad de Agrónomos (CAMACHO, 2003); al-Raqqaqin o arrabal de los Pergamineros, identificado según algunos autores con los restos documentados en Cercadilla (FUERTES, 1995, 267); y los no localizados al-Sichn al-Qadim (la cárcel vieja), masŷid Masrur, masŷid al-Cahfy masŷid Assorur.

Aún sin ser precisa la ubicación de algunos de ellos, las innumerables intervenciones arqueológicas realizadas en la ciudad en las últimas tres décadas han permitido evaluar los ritmos y modos de configuración de este ensanche, conocido como al-Ŷānib al-Garbi. Iniciado su desarrollo a mediados del siglo IX, momento en que se convierte en receptor del incremento demográfico de la ciudad tras la

21 Hacia el sur, con acceso desde la Bab al-Qantara, ya entre los años 716 y 721, las fuentes hacen referencia a la fundación de un cementerio, un arrabal y al acuartelamiento de tropas. Se trata del arrabal de Šaqunda arrasado en el 818 por las tropas de alHakam I, tras la llamada revuelta del arrabal, prohibiéndose desde entonces la reocupación de dicha área, algo que la arqueología confirma fue seguido al pie de la letra (CASAL, 2008). Más tardío, un segundo arrabal, el arrabal de la munyat Ayab, surgido en torno a esta almunia mandada construir por una concubina de al-Hakam I de ese nombre, al que se asociaría el cementerio excavado durante las obras en Ronda Oeste en La Torrecilla (sector no incluido en estas líneas) (CAMACHO, 2001).

22 Hacia el este, en un área ya ocupada por barrios extramuros desde época imperial romana, con acceso desde la Bab al-Hadid, la Bab Ibn 'Abd al-Yabbar y la Bab Rumiyya, la población se extiende desde época emiral en el arrabal de Šabulār, en el que se encontraría la mezquita cuyo alminar se localiza en la actual iglesia de Santiago, interpretada como masŷid 'Amir Hišam (ACIÉN y VALLEJO, 1998, 115; MURILLO, FUERTES y LUNA, 1999, 133); arrabales de munyat 'Abd Allah, en torno a la actual iglesia de San Pablo (MURILLO et alii, 2003) y munyat al-Mugira, en torno a la actual iglesia de San Lorenzo (OCAÑA, 1963, 53-62) junto a las almunias desde las que se formaron; arrabal de al-Bury (La Torre), en torno a la actual iglesia de San Pedro (VAQUERIZO y MURILLO, 2010, 532); y los no localizados, arrabal del Horno de Borrell (Furn Burril), y el rabad al-Zāhira en torno a la residencia palaciega construida por Almanzor, hayib de Hišām II. A diferencia de otros sectores, este sector oriental, al-Šarqiyya, amurallado a partir del siglo XI con motivo de los saqueos bereberes posteriores a la fitna y del avance de las tropas cristianas, sobrevivirá como núcleo urbano y ha estado ocupado hasta nuestros días (RUÍZ LARA et alii, 2003).

23 Hacia el norte, con acceso desde la Bab al-Yahud, y la Bab Luyun, la población se extiende ya desde el tercer cuarto del siglo VIII en torno a almunias del mismo nombre: rabad masŷid Umm Salama en torno a Plaza de Colón (BOTELLA, DIÉGUEZ y MARTíINEZ, 2005); rabad Bab al-Yahud, en la zona del Pretorio (MURILLO et alii, 2003) y rabad al-Rusafa, en las faldas de la Sierra (RODERO y ASENSI, 2006; CÁNOVAS, DORTEZ y MURILLO, 2008; MURILLO et alii, 2010), al que habría que añadir el arrabal mozárabe documentado en la zona de Cercadilla (CASTRO, 2005). 
destrucción de Šaqunda, alcanza su cenit en la siguiente centuria, cuando la ciudad creció al encuentro de Madinnat al-Zahrā', capital del Califato independiente y centro del nuevo Estado omeya, para desparecer con el estallido de la fitna a inicios del siglo XI.

El punto de partida en la génesis de estos arrabales de al-Ŷānib al-Garbī es la vertebración del tejido urbano respecto a los principales caminos de acceso a la ciudad (CP), de trazado este-oeste, y por añadidura, respecto a los elementos asociados a los mismos: cementerios, mezquitas o baños, grandes residencias y alfares. Aun cuando dicha articulación ya ha sido analizada en la zona de Poniente, en áreas más cercanas al recinto de la Medina (VAQUERIZO y MURILLO, 2010), no existe aún análisis para sectores más a occidente de donde nos encontramos. No obstante, teniendo en cuenta todos estos vestigios podemos reconocer que, siendo la extensión de arrabal continua desde el límite murado de la ciudad hasta más allá de Ronda Oeste, la vertebración del tejido urbano respecto a los ejes viarios principales es una constante. Buena parte del viario referenciado en los sectores analizados, perdura fosilizado en distintas vías contemporáneas: Avenida del Zoológico (Camino de las Almunias), Avenida Menéndez Pidal (Camino Intermedio), Calle Pintor Espinosa (Camino de las Abejorreras), Calle Antonio Maura y Carretera de acceso a fábrica ABB (Camino Viejo de Almodóvar) o Nacional A-431 (Cañada Real Soriana, antigua Via Corduba-Hispalis).

Desde estos caminos principales se genera pues un tejido urbano en el que identificamos ejes viarios principales (VP) y ejes viarios secundarios (VS) (Figura 6). Significativamente, en el área cementerial meridional del Sector 3 , documentamos a pequeña escala lo que a gran escala es modelo urbanístico en la zona, pues desde un portón (léase Puerta de la muralla) parten dos calles en abanico (léase
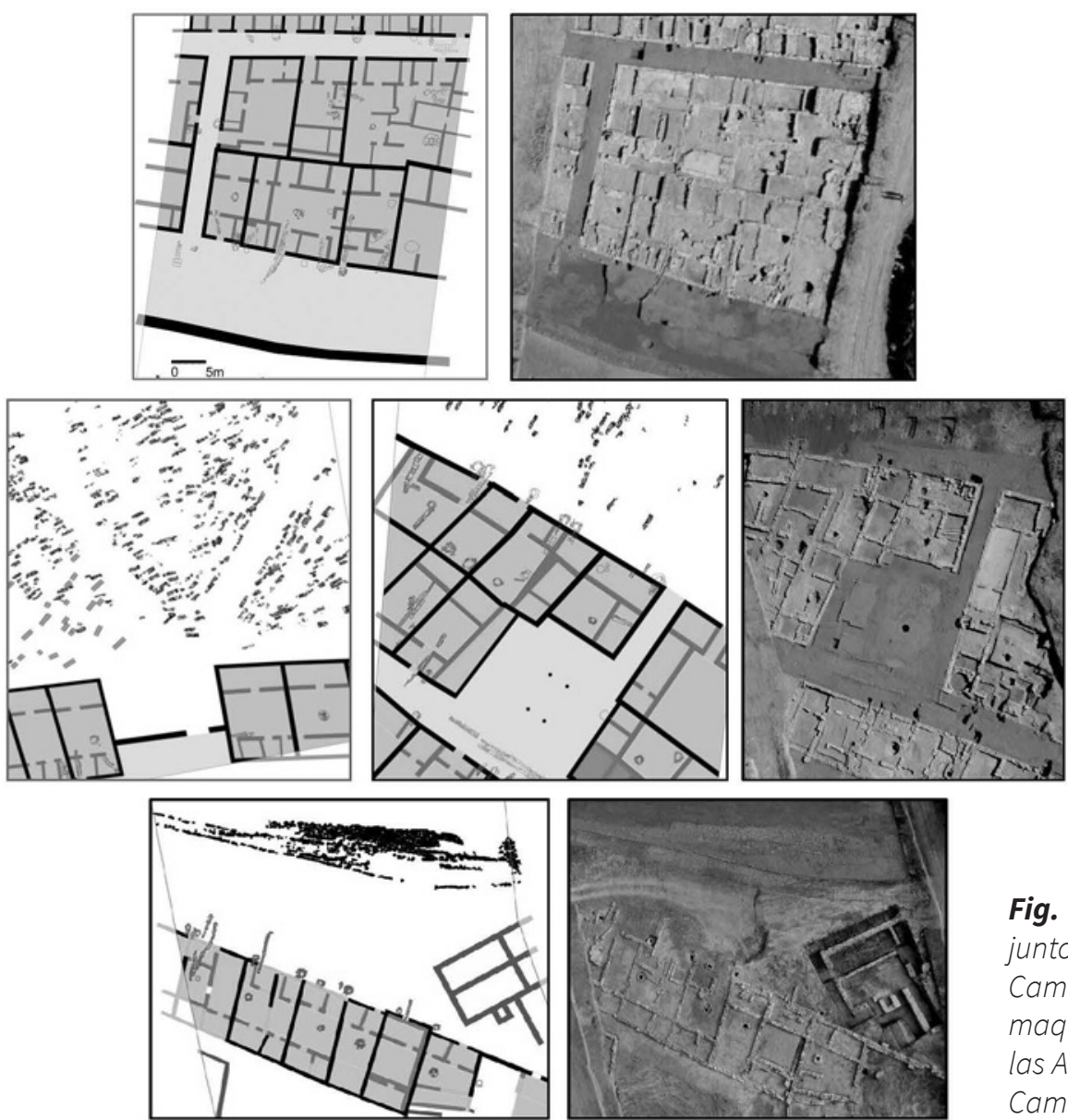

Fig. 6. Procesos edificación junto a caminos. Sector 3 . Camino maqbara norte, maqbara sury Camino de las Abejorreras. Sector 4. Camino de la Matriz. 
Caminos Principales) en torno a las que se distribuyen las inhumaciones (léase Parcelario).

Los primeros orientados de este a oeste o de norte a sur, configurados desde el primer momento de construcción del arrabal, serán los que definan las diversas parcelaciones 0 manzanas. Es frecuente documentar muros pertenecientes a distintas fases constructivas que se superponen, manteniendo así la línea de fachada. Los segundos, abiertos a estas vías principales, de menor tamaño, aparecen en ocasiones cerrados al tránsito en horas nocturnas y, en ellos por lo general, no documentamos realineaciones importantes de las líneas de fachada. Mientras las vías principales serían jurídicamente propiedad colectiva e indivisa sujeta a la iniciativa pública, el resto de entramado de calles y espacios quedó en la esfera de la iniciativa privada, siendo nominalmente titularidad de la comunidad de creyentes (VAN STAEVEL, 1995, 53-57).

\subsection{Génesis del parcelario urba- no: urbanización del espacio}

Vista la definición de este espacio periurbano y su ubicación respecto al viario principal, es obvio que, en el origen de todos los arrabales debió también existir uno o varios elementos primigenios que actuaron como aglutinadores de la población (MURILLO, CASAL y CASTRO, 2004, 261). Si en el origen de los primeros arrabales encontramos, a lo largo del siglo VIII, una gran propiedad o almunia, un antiguo vicus o un centro de culto cristiano, en una segunda etapa, ya a lo largo del siglo IX, a estos primitivos focos -paulatinamente inmersos y engullidos por la trama urbanística de los arrabales-, se añaden fundaciones de carácter piadoso (mezquitas, cementerios, baños y centros asistenciales), por parte de la aristocracia árabe, como recurso ideológico y propagandístico en sectores donde había población que precisaba de estos establecimientos (ACIÉN y VALLEJO, 1989, 133; MURILLO, CASAL y CASTRO, 2004, 266).
Reconocidos en cada sector esos elementos primigenios -caminos, grandes residencias, cementerios, baños, mezquitas y alfares-, la uniforme presencia de tramas de tendencia regular responde, sin embargo, a uno o varios procesos macroespaciales. Así, junto a la edificación en posibles particiones de grandes, medianas y pequeñas propiedades rurales ya analizados, documentamos procesos de agrupación espontánea de unidades domésticas, que generan igualmente un parcelario de manzanas regulares de viviendas surgidas por yuxtaposición (Figura 7). Las primeras unidades domésticas quedan poco a poco inmersas en nuevos ejes de circulación que se jerarquizan, simbólica y materialmente, según predomine su carácter vial (los más amplios destinados a facilitar la comunicación entre diversas áreas del tejido urbano) o residencial (los más estrechos destinados a facilitar el
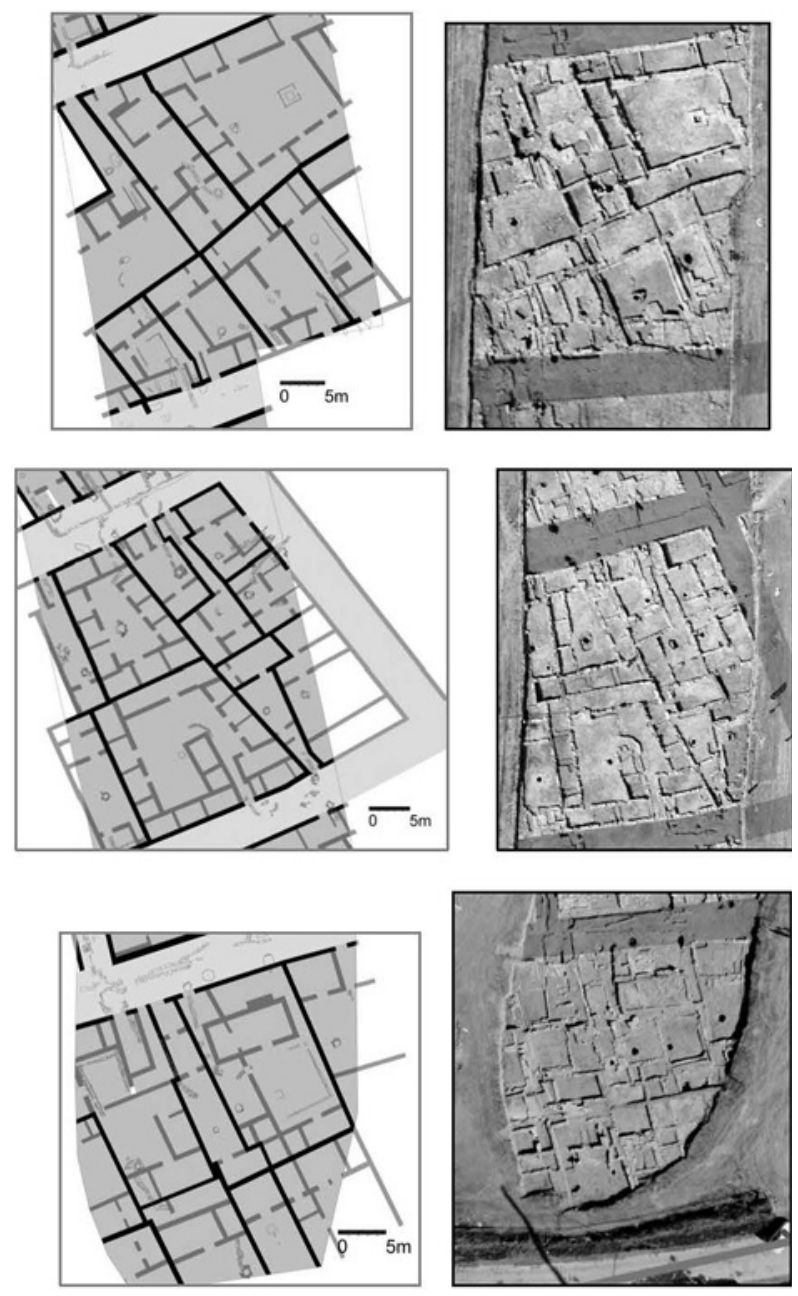

Fig. 7. Proceso de agrupación espontánea. Parcelario por yuxtaposición Sector 3. 
acceso a las unidades domésticas que quedan confinadas en el interior de la manzana). Gracias a una jurisprudencia que favorece el acuerdo entre vecinos y el uso compartido de medianerías, el tejido urbano crece por yuxtaposición (NAVARRO y JIMÉNEZ, 2004, 239; CARMONA, 2015, 209-211). Esta progresión da como resultado, en ocasiones, un tipo de vivienda de planta irregular, adaptada a las características del solar en que se inserta.

Evidencias claras de esta jerarquización encontramos en SECTOR 1, Calle D respecto a Calle A; en SECTOR 2, Calles A, D E, F y G respecto a Calle C y B y en SECTOR 3, Calles $L$ respecto a K, Calle J respecto a Calle G, Calles P, T, Q y S respecto a Calle F, y Calles B, C, D y E respecto a Calle $\mathrm{A}^{24}$ (Figura 8). Como veremos más adelante esta jerarquización se manifiesta en las diferentes definiciones en planta de las viviendas de este viario en la última fase de ocupación del arrabal.

Dado que todo espacio urbano requiere servicios hidráulicos -redes de saneamiento y abastecimiento- que cubran sus necesidades, su origen y autoría aporta también datos esclarecedores sobre los procesos constructivos que han tenido lugar y permiten establecer criterios de edificación diferencial. El análisis de estas infraestructuras nos ayuda a diferenciar aquellos sectores surgidos de forma "espontánea", de aquellos que, por el contrario, fueron "planificados" ex novo, entendiendo esta planificación como la edificación y dotación de infraestructuras de forma colectiva por un grupo de vecinos propietarios. En los últimos años se han intro-
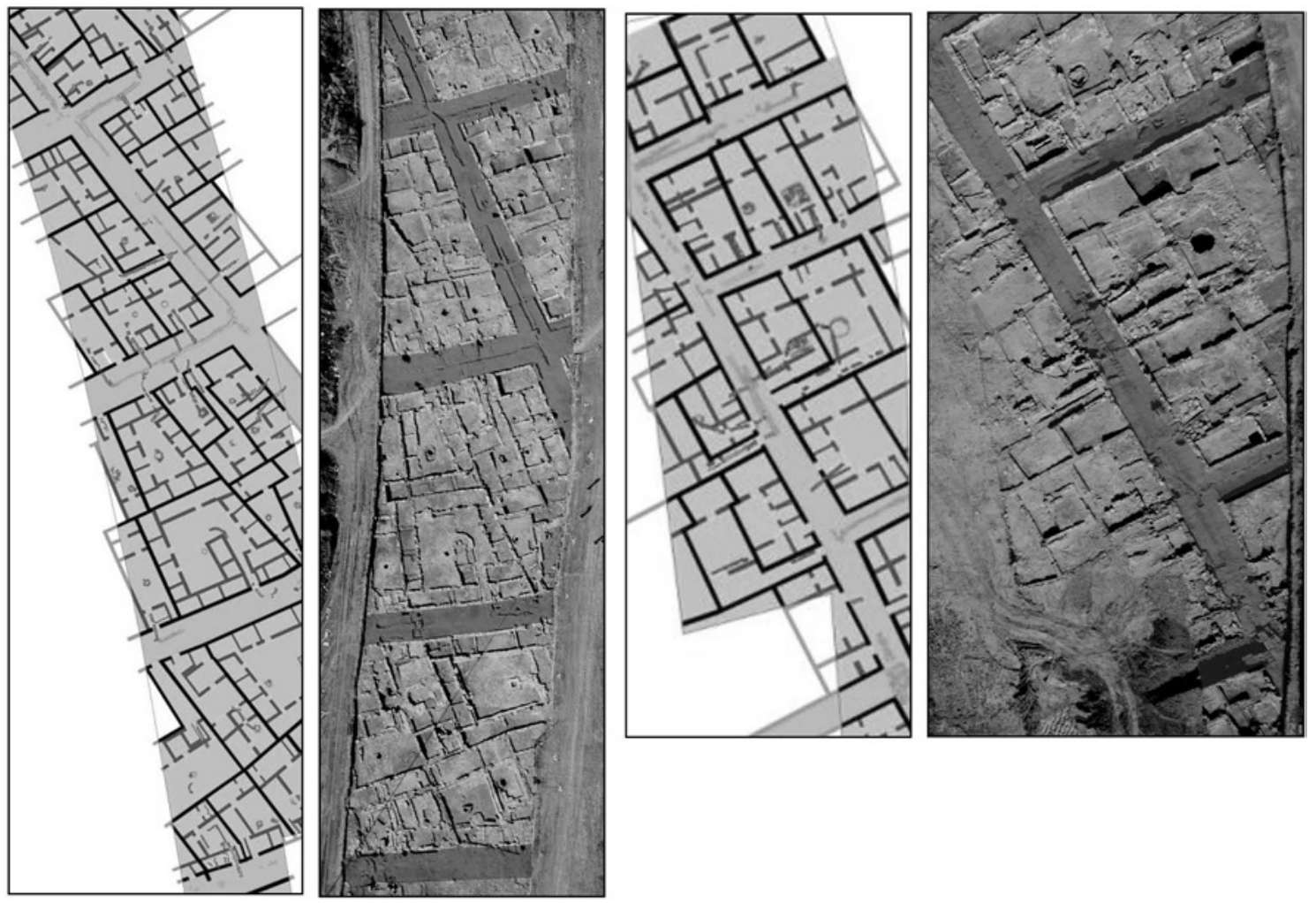

Fig. 8. Proceso jerarquización del viario. Sector 3. Ejes Calles A y F.

24 No debemos confundir esta inicial jerarquización respecto al viario principal con la planificación constatada en otros sectores de la ciudad. En el arrabal meridional cordobés de Šaqunda existe un tejido de grandes ejes viarios con claros indicios de planificación que mantienen su trazado original de mediados del siglo VIII, junto con adarves y plazoletas que dan servicio a las diversas unidades domésticas (CASAL, 2008, 133). En otras urbes como Pechina (primera mitad del siglo X), las unidades domésticas se engarzan unas con otras, definiendo parcelas de contornos irregulares que a menudo se intrusan en las viviendas limítrofes, hecho que ejemplifica el carácter introvertido de la vivienda y quizá el predominio de acuerdos vecinales (ACIÉN, 2001, 28). 
ducido matices argumentales a estas posibles iniciativas colectivas de planificación basadas en posibles acuerdos vecinales (NAVARRO y JIMÉNEZ, 2004, 239; CARMONA, 2015, 209-211). Así, para Vázquez, la instauración del Califato omeya atraería a una gran masa de nuevos habitantes que necesitarían instalarse pronto, y puede que este poder central tomara parte en el asunto acondicionando de manera básica estas vastas extensiones, sin llegar a participar ni en el levantamiento de las manzanas ni en el de las infraestructuras hidráulicas (VÁZQUEZ, 2013, 47). Para Murillo, tras el impulso inicial, en determinados sectores aparecerían una serie de "agentes promotores" encargados de diseñar estos barrios y dotarlos con las infraestructuras mínimas necesarias, incluyendo las hidráulicas (MURILLO, CASAL y CASTRO, 2004, 267). Una vez diseñadas las manzanas, las viviendas se edificarían, bien de forma unitaria, bien en bloque. Es entonces cuando pudieron intervenir unos segundos "promotores" o algún tipo de colectivo privado para su edificación.

En el caso de las redes de saneamiento, se observan diseños uniformes en planta en las viviendas en batería. Pero además en todas las distribuciones del parcelario descritas, las canalizaciones originales de vertido de aguas residuales ${ }^{25}$ se apoyaron sobre las cimentaciones de los muros de fachada, sin que lleguen a producirse zanjas o roturas que indiquen faltas de previsión en el diseño original de las mismas. Sólo en contadas ocasiones documentamos roturas a posteriori, producto de reestructuraciones de la red de evacuación central en relación a modificaciones del parcelario doméstico por preferencias vecinales o por colapsos del alcantarillado debidos a algún fenómeno meteorológico: en Calles A, B y D del SECTOR 1; y Calles F, H, O y Q del SECTOR 3.

Estas canalizaciones, que parten desde los patios y atraviesan el zaguán, finalizan en atarjeas de edilicia más o menos depurada que discurren por las calles o caminos. El destino final de estas aguas pudieron ser cursos de agua como el arroyo documentado bajo la Calle P, que como indican las cotas de nivel, recogería las aguas evacuadas tanto de la Calle F como de la Calle D (VÁZQUEZ, 2016, 280).

Por su parte, el vertido de aguas desde las letrinas se realiza, casi de forma unánime, mediante canalizaciones de tejas invertidas superpuestas que, introducidas bajo el muro de fachada, evacuan a pozos negros ubicados en la calle y sólo en contadas ocasiones en el interior de las viviendas. Como en el caso anterior, se observan diseños uniformes en planta en las viviendas en batería, y la presencia de roturas provocadas en el pavimento por las fosas sépticas son debidas a reestructuraciones por preferencias vecinales o colapsos: en Calle B del SECTOR 1; en Calle A y C del SECTOR 2; en Calles B, F, K y O del SECTOR 3. Además de en los Caminos principales, sólo en la Calle B del SECTOR 4 no documentamos atarjea central y sí pozos negros de diferentes fases, cegados y amortizados sucesivamente.

En el caso de las redes de abastecimiento, el caso de los pozos es más significativo ${ }^{26}$. Existe una diferencia entre las manzanas levantadas en áreas libres de construcciones y las surgidas en torno a algún núcleo aglu-

25 Distinguimos varios tipos de estructuras para vertido residual: canales configurados por sillares cuadrangulares rebajados en forma de $U$ en su parte central; de pequeña mampostería de caliza y algún canto de mediano tamaño, con las paredes y la base revestidas de cal; de baldosas de barro cocido de pasta rojiza sobre cama de mortero de cal; pequeños canalillos realizados con mortero de cal, mostrando una superficie cóncava con sección en U; y canal descubierto, de piedra, ladrillo o teja, a modo de acequia alrededor del patio, ligado a alguno de los sistemas de vertido mencionados.

26 El alumbramiento de aguas mediante un pozo o una fuente era una de las primeras labores realizadas al vivificar unas tierras, y una forma de adquirir su propiedad, ya que el constructor del pozo sería el propietario del agua a no ser que hubiera publicado que lo hizo para uso común o como acto piadoso (VIDAL, 2000, 101-124; 2009). De encañado generalmente circular de entre 60 y $70 \mathrm{~cm}$, distinguimos varios tipos de pozos: de hiladas superpuestas de mampuestos irregulares de caliza, careados al interior, delimitando una estructura de planta circular/ovoidal, ripios de mediano a gran tamaño de diferentes tipos de piedra biocalcarenita, alguna laja de esquisto, cantos y algún cascote cerámico trabados con barro; de sillarejos regulares trabados con barro y pequeños cantos, con brocal cerámico o reforzados con plataformas rebosadero. 
tinador o producto de la compartimentación de un inmueble. En las primeras los pozos se disponen en planta según las preferencias de cada vecino ${ }^{27}$. Encontramos pozos en posición central o desplazada hacia uno de los laterales del patio, en estancia cerrada o no, con más de un pozo, uno de ellos inutilizado, como la no 18 en Calle D de SECTOR 2, o no 82 en Calle M de SECTOR 3; viviendas con pozo compartido, producto de una compartimentación posterior, no 50 y 51 en Calle G de SECTOR 3; y viviendas con pozos heredados de la etapa precedente, como el documentado en la estancia cerrada en la vivienda no 26 en Calle D, o los pozos noria en las viviendas nos 73, 76 y 79 en Calle $K$ de SECTOR 3. Significativamente, en algunas de las segundas existen líneas de pozos paralelas a los muros de fachada, sin duda, trazados en cadena en el momento de su edificación (VÁZQUEZ, 2013, 44). Esta circunstancia se produce en otras ciudades como Almería, donde los barrios de nueva planta parecen seguir un proyecto de urbanización programado (CARA BARRIONUEVO, 1990, 50).

\section{CONSOLIDACIÓN DEL CASERÍO: TIPOS DE VIVIENDAS}

Visto el proceso de urbanización del antiguo espacio agrario y siendo la casa el elemento fundamental en la formación de todo paisaje urbano, el análisis individualizado de cada una de las unidades domésticas identificadas nos permitió constatar parte de la secuencia de consolidación del caserío desarrollada en este ensanche occidental.

La configuración de las viviendas documentadas se ajusta al modelo organizativo más extendido en la arquitectura residencial andalusí, de planta rectangular configurada en torno a un patio central. Gutiérrez Lloret (2012, 152) considera que la introducción y progresiva generalización de este nuevo modelo doméstico de origen mediterráneo, ajeno a la tradición romana, la "casa de patio" o unidad modular compleja estructurada en torno a un patio desemboca en una homogeneización morfológica y funcional de las estructuras domésticas, que puede ser interpretada como la materialización de la islamización social completa ${ }^{28}$. Pero además el modelo organizativo andalusí fue el resultado de un proceso intuitivo de experimentación desarrollando lo que hoy llamamos habilidades bioclimáticas eficaces: orientación, flexibilidad (nomadismo vertical y horizontal) y refrigeración natural con métodos directos o indirectos, manifiestas de forma clara en cada uno de los tipos identificados, si bien, como bien indica García-Pulido, el modelo de vivienda desarrollado por la cultura medieval islámica se adapta a las condiciones particulares y al clima de cada región en que se establece (GARCÍA-PULIDO, 2015, 229-263).

Dentro de este modelo de casa patio distinguimos tres tipos claros según el número

27 Este hecho es casi una regla en sectores excavados del Ŷānib al-Garbī más cercanos a la Medina, surgidos ya a mediados del siglo VIII, pero en el que se documentan grandes espacios vacíos que no llegarían a ser ocupados hasta época califal (BOTELLA, 2001; LÓPEZ REY, 2001; LUNA y ZAMORANO, 1999; RUIZ NIETO, 1999, 2001 y 2005; RUIZ, MURILLO y MORENO, 2001; VENTURA y BERMÚDEZ, 1992; ZAMORANO y LUNA, 1995).

28 Gutiérrez Lloret, 2012, 152 establece la siguiente tipificación de la arquitectura doméstica medieval: módulo unicelular, módulos asociados, módulos agregados delimitando un «protopatio» y, finalmente, unidad modular compleja estructurada en torno a un patio. La descripción literal de estos últimos es la siguiente: Los módulos arquitectónicos se disponen en torno a un patio completamente rodeado de volúmenes construidos (crujías), con entrada demarcada espacialmente mediante un trayecto oblicuo (zaguán en recodo con puertas no alineadas), que al tiempo que regula la circulación segrega visual y espacialmente el patio y garantiza plenamente la preservación de la privacidad y el control de los miembros femeninos del grupo familiar. Este patrón define una unidad doméstica compacta, altamente centralizada y completamente cerrada al exterior, como se aprecia en la ausencia o escasez de ventanas, unicidad de su acceso desde el exterior e incorporación de un nuevo umbral de control de su permeabilidad (el zaguán) entre el exterior y el patio, que jerarquiza notoriamente los diversos niveles de profundidad estructural. (Las habitaciones) se disponen a modo de crujías longitudinales y no se comunican entre sí, sino directamente con el patio, con la sola salvedad de la segregación en el interior de los salones de espacios destinados al reposo, demarcados mediante tabiques, tarimas, plataformas elevadas o arquerías, conocidos en la literatura de la arquitectura doméstica islámica como alcobas o alhanías. Se trata en consecuencia de una unidad doméstica compleja con especialización funcional, que constituye un nuevo modelo doméstico caracterizado por la aparición de las funciones específicas de zaguán en recodo, alcobas y letrina, propio de las sociedades islamizadas en todo el Mediterráneo desde al menos el siglo $X$. 
de alas con acceso desde el patio: viviendas Tipo 1 con dos alas, en ocasiones en $L$ a ambos lados de éste, cerrado con tapia alta; viviendas Tipo 2 con tres alas y viviendas Tipo 3 con cuatro alas ${ }^{29}$ (Figura 9). En este último tipo se incluyen de forma excepcional los tres fanadiq (edificios nos 23, 25 y 30) documentados en SECTOR 3, parte de las primeras unidades domésticas edificadas en el área generada por yuxtaposición entre el Camino Viejo de Almodóvar y la Cañada Real Soriana (Figura 10).

Como punto de partida, sin duda, la morfología del modelo documentado es uno de los factores que define el parcelario en que se inscribe. Por un lado, dado que en la casa islámica el patio y no la calle es la fuente principal de luz y ventilación, no se hacen necesarias grandes fachadas, sólo claros accesos que explican algunas irregularidades en planta: caso de las viviendas con callejón de acceso, también localizadas preferentemente en áreas generadas por yuxtaposición en el SECTOR 3 (Figura 11). Por otro, la búsqueda de habilidades bioclimáticas eficaces (GARCÍA-PULIDO, 2015, 233) explica también la relación de las viviendas con el viario. Así, el emplazamiento de la sala principal al norte se hace casi en la totalidad de las viviendas,
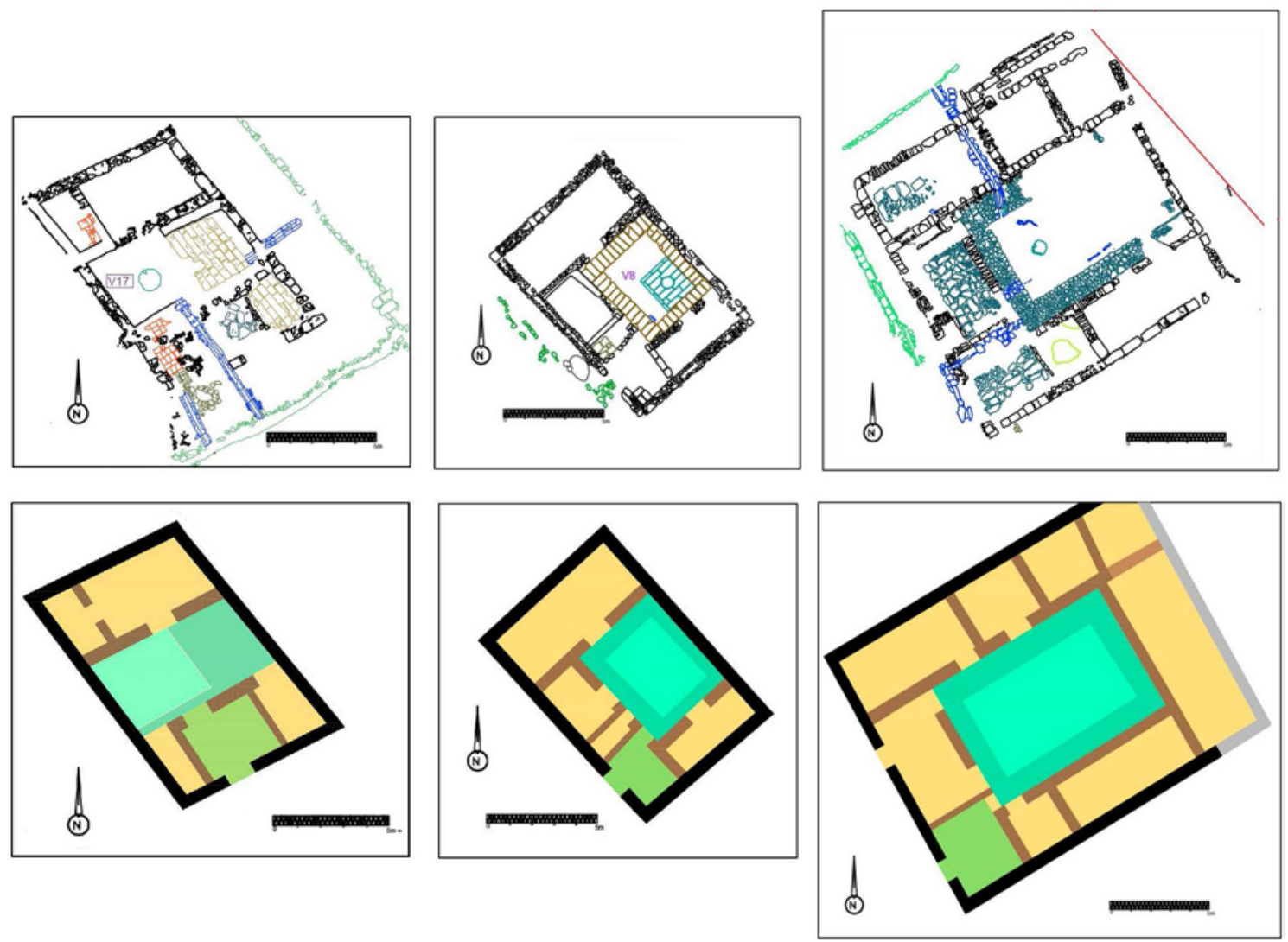

Fig. 9. Tipos de vivienda. Tipo 1 (no 17, Sector 3). Tipo 2 (no 8, Sector 2). Tipo 3 (no 17, Sector 1).

29 Cada una de las viviendas documentadas fueron inventariadas con una ficha creada ex professo, conteniendo datos formales y funcionales. Tres fueron las definiciones originariamente establecidas, por grupo, tamaño y planta-tipo. Distinguimos, en primer lugar, cuatro grupos según la superficie documentada: GRUPO A, legibles en toda su planimetría, GRUPO B, reconstruidas en toda su planimetría, GRUPO C, reconstruidas de forma aproximada a partir de la lógica de la organización espacial, y GRUPO D, identificadas por la relación con elementos estructurales anejos. De los Grupos A, B y C, derivan dos clasificaciones, según tamaño: pequeño (superficie inferior a $80 \mathrm{~m}^{2}$ ), mediano (superficie de entre 80 y $120 \mathrm{~m}^{2}$ ) y gran tamaño (superficie superior a $120 \mathrm{~m}^{2}$ ), y según distribución espacial. Inicialmente establecimos cinco tipos posteriormente revisados y reducidos a cuatro, tras eliminar el denominado de planta irregular con callejón de entrada (CAMACHO, 2008). Similares clasificaciones se han realizado en Córdoba, véase por ejemplo la clasificación para las viviendas califales del arrabal de poniente de CÁNOVAS, CASTRO y MORENO, 2008 y MURILLO et alii, 2010, 589-603. 

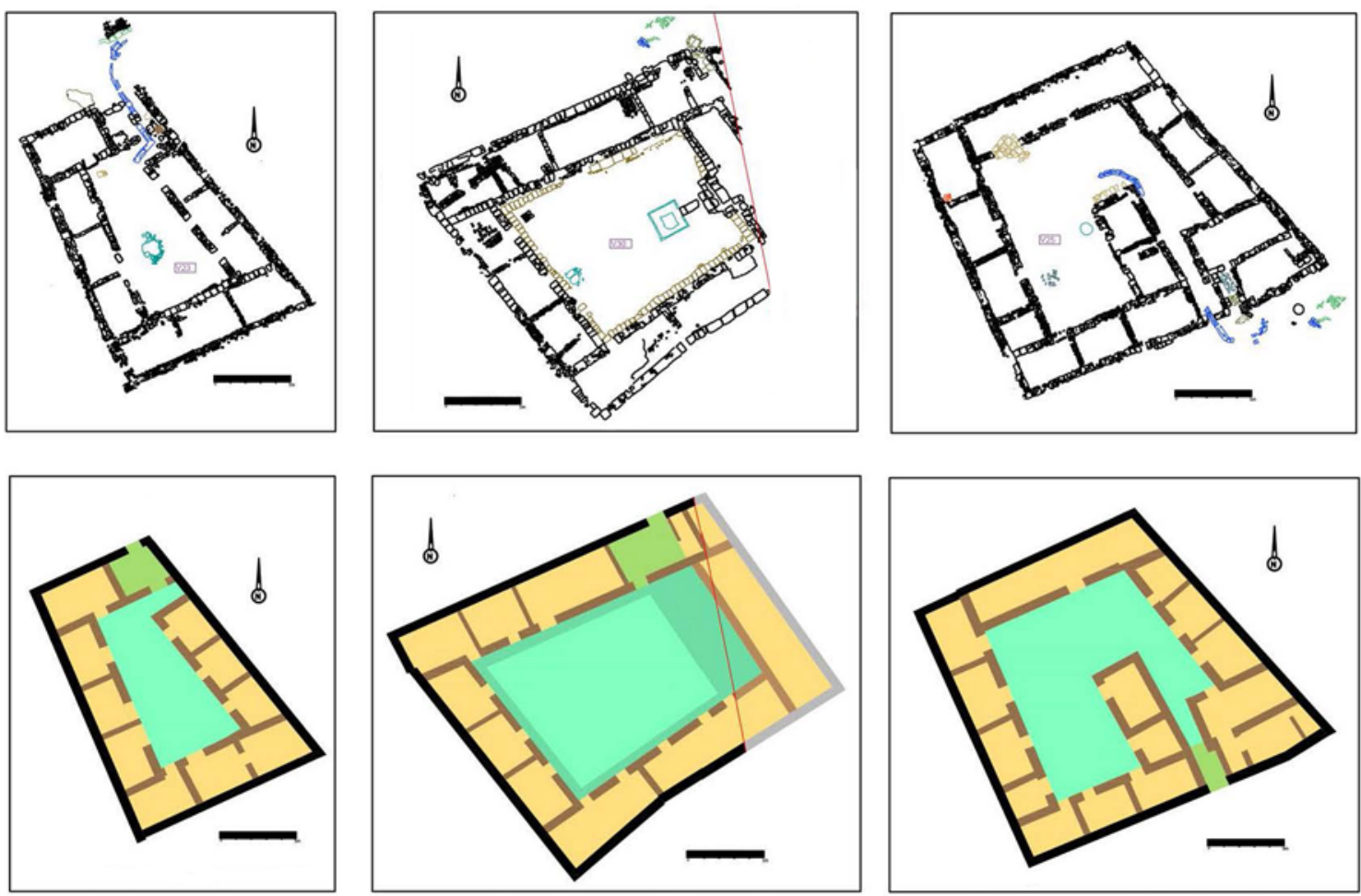

Fig. 10. Fanadiq Sector 3 Ronda Oeste de Córdoba.
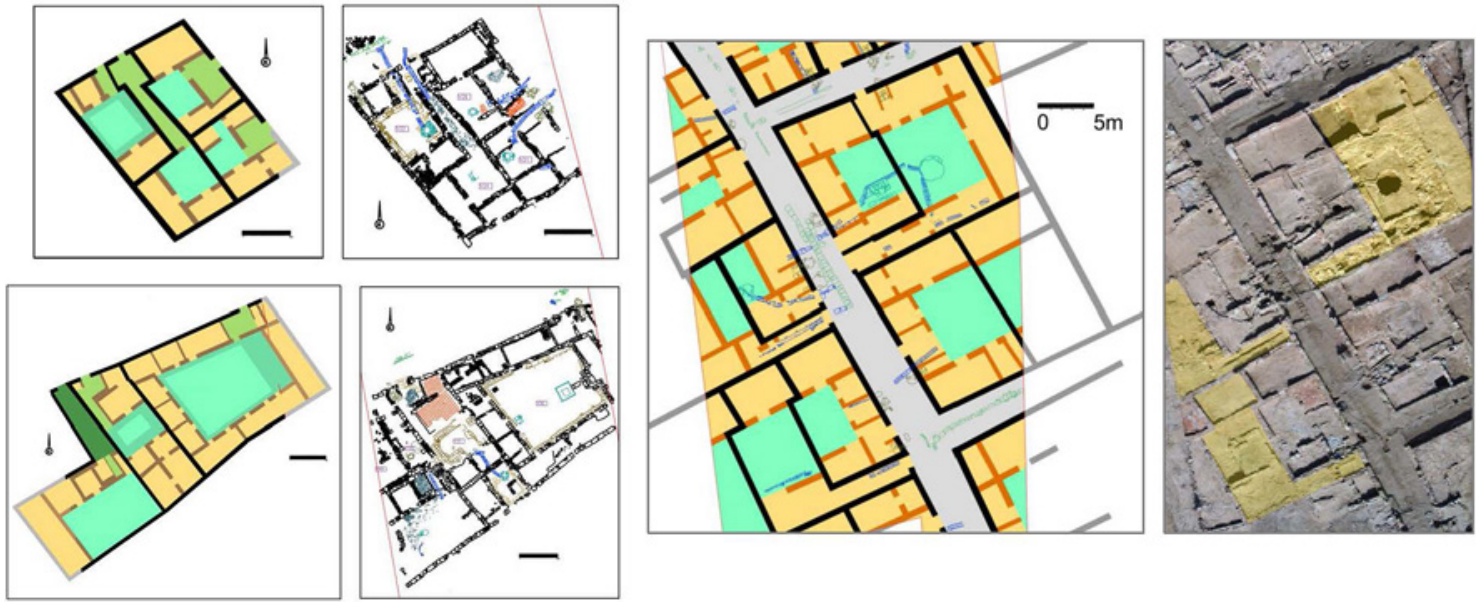

Fig. 11. Vivienda con callejón de acceso. Casas nos 24, 32, 117, 119 y 123. Sector 3.

siempre que las limitaciones de la parcela lo permiten y por encima de otros condicionantes, incluso a costa de tener que absorber irregularidades en otras dependencias; la flexibilidad estacional se hace posible en las viviendas de tres y cuatro alas; y los métodos indirectos para atenuar el calor están presentes en la construcción de jardines y alberquitas en algunos patios.
Pero ies posible asociar los diferentes tipos de vivienda documentados a uno o más procesos evolutivos? La distribución de tipos y tamaños por sectores (cifras contabilizadas para la última fase constructiva) nos permite establecer relaciones entre diferentes procesos macroespaciales. En términos generales, la más variada tipología y tamaño de las viviendas es directamente proporcional al 
número de procesos evolutivos manifiestos. La vivienda Tipo 1 es mayoritaria es todos los sectores, excepto en el SECTOR 1, el de cronología más temprana y en el que, por consiguiente, la evolución del parcelario ha llegado a sufrir más variaciones. En la misma medida, la más larga vida del arrabal en este sector se manifiesta no sólo en las reformas producidas en el viario, sino en las numerosas modificaciones estructurales observadas en el $64 \%$ de las viviendas contabilizadas. El porcentaje para el resto de los sectores es marcadamente inferior: $33 \%$ en SECTOR 2, 33\% en SECTOR 3 y 23\% en SECTOR 4.

\section{LA EXPANSIÓN Y SATURACIÓN DEL CASERÍO}

Considerando la totalidad de la superficie intervenida como unidad porcentual, la densidad de ocupación urbana documentada (DOU) ${ }^{30}$ en la etapa previa al abandono de las estructuras en cada uno de los sectores, es un indicio más del proceso evolutivo alcanzado. Así, en los sectores situados más al sur la definitiva ocupación de áreas vacías - espacios verdes se realiza sobre un $100 \%$ de la superficie, mientras la ocupación urbana en el sector más septentrional no alcanza el $55 \%$. Se confirma así, como ya indicaran Acién y Vallejo, que el proceso de crecimiento de los arrabales se produciría desde la zona más meridional en torno a la Balāt Mugit hacia el norte y hacia el oeste, encontrando en ambas direcciones estructuras cada vez más próximas a la cultura material desarrollada en Madīnat al-Zahrā' (ACIÉN y VALLEJO, 1998, 121).

Reconocida en esta densidad la definitiva expansión del caserío en estos ensanches occidentales, entre los procesos evolutivos identificados en el parcelario doméstico encontramos además reformas de carácter puntual y reformas de carácter estructural.
Entre las primeras, documentamos ampliaciones o reducciones de superficie en estancias, modificaciones de uso, evidenciadas en amortizaciones de pavimentos y/o estructuras hidráulicas y edificación posterior a la fundación de cuerpos exentos en el patio ${ }^{31}$. Entre las segundas, documentamos pérdidas de espacio de una vivienda en beneficio de la adyacente, como resultado de posibles acuerdos vecinales y subdivisión de viviendas debidas a posibles repartos hereditarios (GUTIÉRREZ LLORET, 2012, 154). La normativa vigente en al-Andalus no permitía dividir la casa en tanto no le quedara a cada uno de los propietarios una parte que fuera aprovechable y que le permitiera aislarse de los otros, no sólo respecto a las habitaciones sino también respecto al patio (CARMONA, 2015, 222).

Aunque en ningún caso la ejecución de reformas puntuales o la edificación de nuevas viviendas responden a un problema de falta de espacio, hay ciertas afecciones al parcelario que denotan el inicio de un proceso de saturación. Además de las evidentes afecciones a la red viaria debidas a la inclusión de nuevas estructuras hidráulicas (pozos negros y canalizaciones), en algunos casos documentamos invasiones del espacio público (ampliación del baño sobre Calle A en SECTOR 1; vivienda n. ${ }^{\circ}$ 47 en Calle J de SECTOR 3) y sólo en un caso creación de una nueva vía secundaria o adarve, con acceso a una sola vivienda, pero con vertido de varias de las adyacentes (vivienda n. 32 en SECTOR 3) (Figura 12).

\section{EL ABANDONO}

Una vez producido el abandono y la paulatina destrucción y arrasamiento del arrabal se inicia la fase de colmatación de los derrumbes y las estructuras aún emergentes. Documentamos en casi la totalidad de las habitaciones una cobertura de tejas caídas de distinta

30 Superficie con estructuras asociadas a unidades de habitación, incluyendo en dichas unidades el viario, áreas industriales, de culto y cementeriales.

31 Reformas analizadas en el estudio individualizado de que han sido objeto las viviendas exhumadas en Ronda Oeste Córdoba, que serán objeto de futuras reflexiones. 

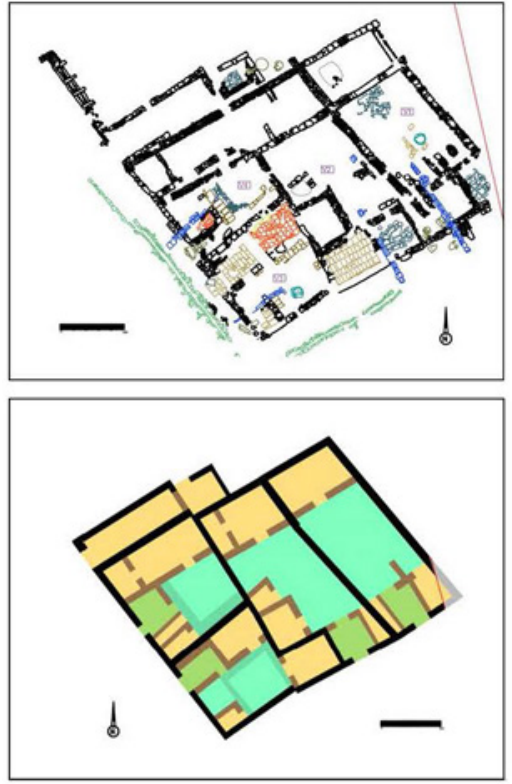
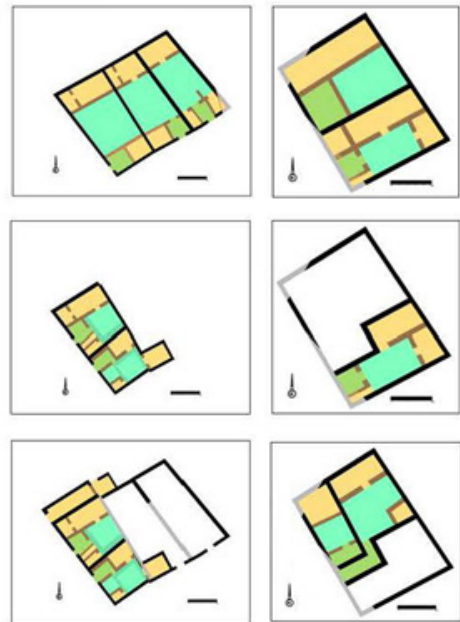
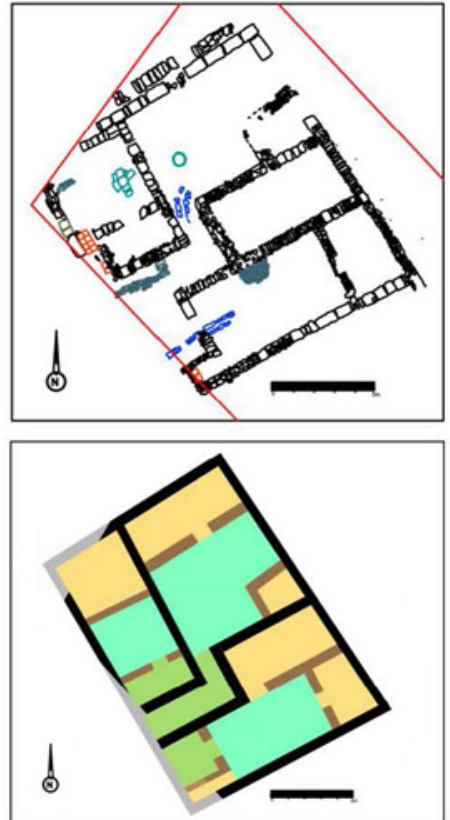

Fig. 12. Reformas de carácter estructural en viviendas. Casa no 12-14-15. Sector 1. Casas nos 2-3-4. Sector 3).

potencia. Cubriéndolas y entre las tejas, el material cerámico es el mismo, sin nuevos aportes, lo que indica que, tras el abandono y ruina de las viviendas, se inicia de forma inmediata su expolio.

Terminado el conflicto civil, Qurțuba se vio envuelta en una serie de continuas transformaciones de carácter político y social. Durante los Reinos de Taifas, y bajo el dominio de los imperios Almorávide y Almohade, los barrios residenciales occidentales no volvieron a ocuparse, apenas se levantaron nuevas construcciones y sólo surgieron algunos recintos de carácter industrial (BLANCO, 2014, 650-653). En época tardoislámica comenzó un importante expolio de materiales de construcción y se han documentado dos grandes hornos de cal, ambos en el SECTOR 3. A partir de este momento, en época moderna y contemporánea, estos terrenos fueron usados principalmente como tierra de labor o ganadera. Será a finales del XIX e inicios del XX, momento en que surgen en los aledaños las primeras barriadas periféricas, cuando comencemos a ver de nuevo actividad: parcelaciones edificadas, grandes albercas, acequias y cercados en todos los sectores estudiados.

\section{BIBLIOGRAFÍA}

ACIÉN, M. (2001): "La formación del tejido urbano en alAndalus" en PASSINI, J., La ciudad medieval: de la casa al tejido urbano. Actas del primer Curso de Historia y Urbanismo Medieval organizado por la Universidad de Castilla-La Mancha, pp. 11-32.

ACIÉN, M. y VALLEJO, A. (1998): "Urbanismo y estado islámico: de Corduba a Qurtuba-Mad nat al-Zahr '” en Gènese de la ville islamique en al-Andalus et au Maghreb occidental, Madrid, pp. 107-136.

APARICIO SÁNCHEZ, L. (2008): "Redes de abastecimiento y evacuación de agua en los arrabales califales de Córdoba", Arte, Arqueología e Historia, no 15, Córdoba, pp. 237-256.

APARICIO SÁNCHEZ, L. (2008): "La planificación urbanística en la Córdoba Califal. Los arrabales noroccidentales" en BICHO, N. y CARVALHO, A. F. (Coords.): Actas do IV Congresso de Arqueología Peninsular (Faro, 2004), pp. 29-38.

APARICIO SÁNCHEZ, L. y RIQUELME CANTAL, J. A. (2008): "Localización de uno de los arrabales noroccidentales de Córdoba Califal. Estudio urbanístico y zooarqueológico", Cuadernos de Madinat al-Zahrā', nº 6, Córdoba, pp. 93-131.

ARJONA CASTRO, Antonio (1982): Anales de la Córdoba Musulmana (711-1008). Córdoba, Monte de Piedad y Caja de Ahorros de Córdoba.

BAENA ALCÁNTARA, Ma D.; CANTO GARCÍA, A.; CAMACHO, C.; MORENO GARRIDO, Ma J.; CABELLO, A. y MARTÍN ESCUDERO, F. (2007): Maskukat. Tesoros de monedas andalusíes en el Museo Arqueológico de Córdoba. Catálogo de la Exposición, Córdoba. 
BAZZANA, André (1995): "Urbanismo e hidráulica (urbana y doméstica) en la ciudad almohade de Saltés (Huelva)", Casas y palacios de al-Andalus. Barcelona-Granada, pp. 139-156.

BERMÚDEZ CANO, J. M. (1993): "La trama viaria propia de Madinat al-Zahra' y su integración con la de Córdoba", Anales de Arqueología Cordobesa, no 4, Córdoba, pp. 259-294.

BLANCO GUZMÁN, R. (2008): "Algunas precisiones sobre la Qurtuba tardoislámica. Una mirada a la arquitectura doméstica de al-Rabad al-Šarqi", Anales de Arqueología Cordobesa, n 19, Córdoba, pp. 293-322.

BLANCO GUZMÁN, R. (2014): "Una ciudad en transición: el inicio de la Córdoba islámica” en VAQUERIZO GIL, D.; GARRIGUET, J. A. y LEÓN, A. (Eds.): Ciudad y territorio: transformaciones materiales e ideológicas entre la época clásica y el Altomedioevo, Universidad de Córdoba, Córdoba, pp. 185-200.

BLANCO GUZMÁN, R. (2014): La arquitectura doméstica tardoislámica en Qurțba (ss. XII-XIII), Tesis doctoral, Universidad de Córdoba, Córdoba.

BOTELLA, D. (2001): "Excavación Arqueológica de Urgencia en el Edificio Occidente (Parcela A-4, Manzana 9, Polígono 3, P1) de Córdoba", Anuario Arqueológico de Andalucía 1996/III Actividades de Urgencia, Sevilla, pp. 143-152.

BOTELLA, D., DIÉGUEZ, J. P., MARTíNEZ, V., MORENA, J. A. (2005): "Evidencias arqueológicas de un cementerio andalusí en Córdoba ¿La Maqbara Umm Salama?”, Boletín de Arqueología Medieval, no 12, pp. 19-50.

CAMACHO CRUZ, C. (2002): "Nuevos vestigios arqueológicos de la Córdoba Omeya. Actuaciones arqueológicas en el trazado de la Ronda Oeste de Poniente", Arte, Arqueología e Historia, no 9, Córdoba, pp. 118-132.

CAMACHO CRUZ, C. (2004): "Intervención Arqueológica de Urgencia en Ronda Oeste de Córdoba. Yacimiento necrópolis Polígono Industrial "La Torrecilla", en Anuario Arqueológico de Andalucía 2001 / III Actividades de Urgencia, Sevilla, pp. 231-243.

CAMACHO CRUZ, C. (2007): "Ensayo de tipología formal de Candiles de Piquera. Ejemplos de ritual funerario en necrópolis islámicas cordobesas", Arte, Arqueología e Historia, n 14, Córdoba, pp. 219-229.

CAMACHO CRUZ, C. (2008): "Estudio sobre pavimentación en la vivienda del siglo X”, Arte, Arqueología e Historia, nº 15, Córdoba, pp. 221-235.

CAMACHO CRUZ, C. (2010): "La almunia de la Ronda Oeste. Un hito en la arqueología cordobesa", Arte, Arqueología e Historia, no 17, Córdoba, pp. 173-181.

CAMACHO, C. (2010a): Ponencia "Excavación de una casa palatina del arrabal califal de Poniente. Córdoba", 20 Seminario. Palacios Medievales 1. Jueves mínimos en la Cuesta del Chapiz, Granada, 11 de noviembre de 2010.

CAMACHO, C. (2013): Ponencia "Evolución del parcelario doméstico y su interacción con la trama urbana: el caso de los arrabales califales de Córdoba", 60 Seminario. Casas Medievales 1. Jueves mínimos en la Cuesta del Chapiz, Granada, 4 de julio de 2013.
CAMACHO, C. (2015): "Candiles de piquera. Morfología y uso en la Córdoba del siglo X", Actas do X Congreso Internacional A Cerâmica Medieval no Mediterrâneo, Silve SilvesMértola, 22 a 27 de outubro de 2012, Silves, pp. 248-252.

CAMACHO CRUZ, C. y HARO TORRES, M. (2009): "Necrópolis romana en Yacimiento Carretera de Palma del Río. Campaña 2004. Ronda Oeste de Córdoba", Anuario Arqueológico de Andalucía 2004.1 / III Actividades de Urgencia, Sevilla, pp. 1069-1081.

CAMACHO CRUZ, C. y HARO TORRES, M. (2010): "Arrabales occidentales de Qurtuba: estudio sobre pavimentación en el siglo X. Intervención Arqueológica de Urgencia en Yacimiento Carretera del Aeropuerto. Arrabal (Campaña 2005-2006). Ronda Oeste de Córdoba", Anuario Arqueológico de Andalucía 2006 / III Actividades de Urgencia, Sevilla, pp. 1209-1223.

CAMACHO CRUZ, Cristina; HARO TORRES, Miguel; LARA FUILLERAT, José Manuel; PÉREZ NAVARRO, César (2004): "Intervención arqueológica de urgencia en el arrabal hispanomusulmán "Casas del Naranjal". Yacimiento "D". Ronda Oeste de Córdoba", Anuario Arqueológico de Andalucía 2001.1 / III Actividades de Urgencia, Sevilla, Junta de Andalucía, pp. 210-230.

CAMACHO CRUZ, C., HARO TORRES, M., LARA FUILLERAT, J.M., PÉREZ NAVARRO, C. (2009): "Intervención Arqueológica de Urgencia en Yacimiento Carretera del Aeropuerto. Almunia (Campaña 2003-2004). Ronda Oeste de Córdoba", Anuario Arqueológico de Andalucía 2004.1 / III Actividades de Urgencia, Sevilla, pp. 778-788.

CAMACHO CRUZ, C., CABELLOS PANADÉS, T., HARO TORRES, M., LARA FUILLERAT, J.M., PÉREZ NAVARRO, C. (2009a): "Intervención Arqueológica de Urgencia en Yacimiento Carretera del Aeropuerto. Necrópolis (Campañas 2001/2003-2004). Ronda Oeste de Córdoba", Anuario Arqueológico de Andalucía 2004 / III Actividades de Urgencia, Sevilla, pp. 1051-1068.

CAMACHO, C. y HARO TORRES, M. (2009b): “Intervención Arqueológica de Urgencia en Yacimiento Electromecánica. Campaña 2004. Ronda Oeste de Córdoba", en Anuario Arqueológico de Andalucía 2004 / III Actividades de Urgencia, Sevilla, pp. 1082-1094.

CAMACHO CRUZ, C., HARO TORRES, M. y PÉREZ NAVARRO, C. (2009c): "Restos de ocupación medieval islámica en Yacimiento Carretera de Palma del Río. Campaña 2004. Ronda Oeste de Córdoba", Anuario Arqueológico de Andalucía 2004.1 / III Actividades de urgencia, Sevilla, pp. 1105-1119.

CAMACHO CRUZ, C., HARO TORRES, M., LARA FUILLERAT, J.M., PÉREZ NAVARRO, C. (2009d): "Arrabales occidentales de Qurtuba: modelo urbanístico y doméstico. Intervención Arqueológica de Urgencia en Yacimiento Carretera del Aeropuerto. Arrabal (Campañas 2001/2003-2004). Ronda Oeste de Córdoba", Anuario Arqueológico de Andalucía 2004.1 /III Actividades de Urgencia, Sevilla, pp. 1143-1163.

CAMPS, C., MARTÍ, J., BLASCO, J., LERMA, J.V., LÓPEZ, I., PASCUAL, J. (1990): "La vivienda islámica en la ciudad de Valencia. Una aproximación de conjunto", La casa hispano-musulmana. Aportaciones de la arqueología, Granada, pp. 305-318. 
CÁNOVAS UBERA, Álvaro; CASTRO DEL RÍO, Elena; MORENO ALMENARA, Maudilio (2008): "Análisis de los espacios domésticos en un sector de los arrabales occidentales de Qurtuba", Anejos de Anales Arqueología Cordobesa, no 1, Córdoba, pp. 201-220.

CÁNOVAS, A., DORTEZ, M, T. y MURILLO, J. F. (2008): Informe preliminar de resultados de la 1 a fase de la A.A.PRe. en la manzana M-A, polígono 1 del P.P. MA-1, (Calle Teruel, Córdoba), Informe Administrativo depositado en la Delegación Provincial de Cultura de Córdoba (inédito), Córdoba.

CÁNOVAS UBERA, Álvaro; MORENO ALMENARA, Maudilio (2009): "Actividad Arqueológica Preventiva realizada en los terrenos proyectados para la Piscina Municipal de Poniente de Córdoba", Anuario Arqueológico de Andalucía 2004 / III Actividades de Urgencia, Vol. 1, Sevilla, Junta de Andalucía, pp.1033-1044.

CANTO GARCÍA, A. y CAMACHO, C. (2009): "Hallazgos monetarios, de época califal, en las excavaciones de los arrabales de Córdoba", Actas XIII Congreso Nacional de Numismática «Moneda y Arqueología», Tomo I, (Cádiz, 22-24 de octubre de 2007), Madrid-Cádiz, pp. 801-820.

CARA BARRIONUEVO, L. (1990): La Almería islámica y su Alcazaba, Cajal, Almería.

CARMONA, Alfonso (2015): "Casos de litigios de vecindad en al-Andalus", en DÍEZ JORGE, M.E. y NAVARRO PALAZÓN, J. (Eds.): La casa medieval en la Península Ibérica, Madrid, pp. 209-227.

CASAL GARCÍA, María Teresa (2003): Los cementerios musulmanes de Qurtuba, Córdoba.

CASAL GARCÍA, María Teresa (2008): "Características generales del urbanismo cordobés de la primera etapa emiral: el arrabal de Šaqunda", Anejos de Anales de Arqueología Cordobesa, no 1, Córdoba, Universidad de Córdoba, pp. 109-134.

CASAL, M. T., VALDIVIESO, A., LEÓN, ASORIANO, P., LÓPEZ, R. (2006): "Espacio y usos funerarios en la Qurtuba islámica", Anales de Arqueología Cordobesa, no 17, vol. II, Córdoba, pp. 257-290.

CASTILLO, F. y MARTÍNEZ, R. (1990): "La vivienda hispanomusulmana de Bayyâna-Pechina (Almería)", La casa hispano-musulmana. Aportaciones de la arqueología, Granada, pp. 111-127.

CASTILLO, F. y MARTíNEZ, R. (1993): “Excavación sistemática del yacimiento hispanomusulmán de Baayyâna (Pechina-Almería). IIla Campaña, 1988. Informe preliminar", Anuario Arqueológico de Andalucía 1991 / II Actividades sistemáticas, Sevilla, pp. 52-62.

CASTRO DEL RÍO, Elena (2001): "La arquitectura doméstica en los arrabales de la Córdoba califal: la Zona Arqueológica de Cercadilla", Anales de Arqueología Cordobesa, no 12, Córdoba, pp.241-281.

CASTRO DEL RÍO, Elena (2005): El arrabal de época califal de la zona arqueológica de Cercadilla: la arquitectura doméstica. Monografías de Arqueología Cordobesa, 12. Córdoba.
CLAPÉS SALMORAL, Rafael (2014-2015): "La actividad comercial de Córdoba en época califal a través de un edificio hallado en el arrabal de Poniente", Anales de Arqueología Cordobesa, n²5-26, Córdoba, pp. 225-254.

DORTEZ CÁCERES, Teresa (2010): "Urbanismo islámico en el sector central del Yanib al-Garbi", en VAQUERIZO GIL, Desiderio; MURILLO REDONDO, Juan Francisco: El anfiteatro romano de Córdoba y su entorno urbano. Análisis arqueológico (ss. I-XIII). Vol. II, Córdoba, pp. 621-629.

EPALZA, M. (1992): "Espacios y sus funciones en la ciudad árabe", Simposio Internacional sobre La Ciudad Islámica. Ponencias y comunicaciones, Zaragoza, pp. 9-30.

FUERTES SANTOS, María Camino (1995): "Un conjunto cerámico post-califal procedente del yacimiento de Cercadilla", Anales de Arqueología Cordobesa, n 6, Córdoba, pp. 265-291.

FUERTES SANTOS, María Camino (2002): “Aproximación al urbanismo y la arquitectura doméstica de época califal del Yacimiento de Cercadilla", Arqueología y Territorio Medieval, no 9, Jaén, pp. 105-126.

FUERTES SANTOS, María Camino (2007): "El Sector Nororiental del arrabal califal del yacimiento de Cercadilla. Análisis urbanístico y arquitectónico", Arqueología y Territorio Medieval, no 14, Jaén, pp. 49-68.

GARCÍA GÓMEZ, Emilio (1965): "Notas sobre la topografía cordobesa en los "Anales de al-Hakam II" por 'İsà Rāzī", Al-Andalus, XXX, pp. 319-379.

GARCÍA-BELLIDO Y GARCÍA DE DIEGO, Javier (1997): "Principios y reglas morfogenéticas de la ciudad islámica”, Qurtuba, n², Córdoba, pp.59-86.

GARCÍA-BELLIDO Y GARCÍA DE DIEGO, Javier (2001): "Morfogénesis de la ciudad islámica: algunas cuestiones abiertas y ciertas propuestas explicativas", L'urbanisme dans l'Occident musulman au Moyen Âge. Aspects juridiques, Madrid, Casa de Velázquez, CSIC, pp. 243-283.

GARCÍA-PULIDO, Luis J. (2015): "Respuestas de las viviendas andalusíes a los condicionantes climáticos. Algunos casos de estudio", en DÍEZ JORGE, M.E. y NAVARRO PALAZÓN, J. (Eds.): La casa medieval en la Península Ibérica, Madrid, pp. 229-263.

GONZÁLEZ GUTIÉRREZ, Carmen (2012): Las mezquitas de barrio de Madinat Qurtuba: una aproximación arqueológica. Córdoba.

GONZÁLEZ GUTIÉRREZ, Carmen (2014): "Hacia la ciudad islámica: de la percepción tradicional a la conceptualización arqueológica", en VAQUERIZO, D.; GARRIGUET, J. A.; LEÓN, A. (Eds.): Ciudad y territorio: transformaciones materiales e ideológicas entre la época clásica y el Altomedievo, Monografías de Arqueología cordobesa no 20, Córdoba, pp. 201-214.

GONZÁLEZ GUTIÉRREZ, Carmen (2016): Las mezquitas de la Córdoba islámica. Concepto, tipología y función urbana, Tesis doctoral, Universidad de Córdoba, Córdoba. 
GUTIÉRREZ LLORET, Sonia (2012): "Gramática de la casa. Perspectivas de análisis arqueológico de los espacios domésticos medievales en la península Ibérica (siglos VIIXIII)", Arqueología de la arquitectura, 9, enero-diciembre 2012, pp. 139-164

HARO TORRES, Miguel y CAMACHO CRUZ, Cristina (2007): "Dos formas de almacenar el agua. Ronda Oeste", Arte, Arqueología e Historia. no 14, Córdoba, Asociación Arte, Arqueología e Historia, pp. 197-204.

IBN HAYYĀNN, Anales palatinos del Califa de Córdoba al-Hakam II, por 'T́sā ibn Ahmad al-Rāzì (360- 364 H. = 971975 J. C.), trad. E. García Gómez. Madrid, 1967.

IZQUIERDO, R. (1990): "La vivienda en la ciudad hispanomusulmana de Vascos (Toledo). Estudio arqueológico", La casa hispano-musulmana. Aportaciones de la arqueología, Granada, pp. 147-162

LEÓN MUÑOZ, A. (2006): "Pervivencias de elementos clásicos en la Qurtuba islámica” en VAQUERIZO, D. y MURILLO, J.F. (Edits.), El concepto de lo provincial en el mundo antiquo. Homenaje a la profesora Pilar León Alonso, Vol. II, Córdoba, pp. 409-438.

LEÓN MUÑOZ, A., LEÓN, E. y MURILLO, J. F. (2008): "El Guadalquivir y las fortificaciones urbanas de Córdoba”, IV Congreso Internacional sobre fortificaciones "Las Fortificaciones y el mar”, Alcalá de Guadaira, pp. 261-290.

LÓPEZ CUEVAS, F. (2013): "La almunia cordobesa, entre las fuentes historiográficas y arqueológicas”, Onoba, nº 1, pp. 243-260.

LÓPEZ REY, N. (2001): "Resultados de la I.A.U. en la parcela C, manzana 1 de Polígono 3 de Poniente 1 (Edificio Praga) de Córdoba", Anuario Arqueológico de Andalucía 1997 / III Actividades de Urgencia, Sevilla, Junta de Andalucía, pp. 209-212.

LUNA, Dolores; ZAMORANO, Ana (1999): "La mezquita de la antigua finca "El Fontanar" (Córdoba)", Cuadernos de Madinat al-Zahra, no 4, Córdoba, pp. 145-173.

MACÍAS, S.; TORRES, C. (1995): "El barrio almohade de la alcazaba de Mérida: el espacio cocina”, Casas y palacios de al-Andalus. Siglos XII y XIII, Barcelona-Granada, pp. 165-175.

MARTAGÓN MAESA, María (2009/2010): "Qurțuba y su territorio: una aproximación al entorno rural de la ciudad islámica", Anejos de Anales de Arqueología Cordobesa, no 2, Córdoba, pp. 303-326.

MAZZOLI-GUINTARD, Christine (2000): Ciudades de al Andalus. España y Portugal en la época musulmana (siglos VIII-XV), Granada, Almed.

MAZZOLI-GUINTARD, C. (2003): Vivre a Cordoue au Moyen Âge. Solidarité citadine en terre d'Islam auxXe-Xie siècles, Rennes.

MORALES, R., GARCÍA, J.L., CARA, L. (2003): “Urbanismo y vivienda en la Almería medieval a la luz de las últimas excavaciones arqueológicas", Anuario Arqueológico de Urgencia 2000 / III Actividades de Urgencia, Sevilla, Junta de Andalucía, pp. 37-46.
MORENO ROSA, Antonio, PIZARRO BERENGENA, Guadalupe (2010): "La continuidad de los sistemas hidráulicos. Nuevos testimonios en Córdoba", Aquam perducendam curavit. Captación, uso y administración del agua en las ciudades de la Bética y el occidente romano, Cádiz, Universidad de Cádiz, pp. 165-182.

MURILLO REDONDO, Juan Francisco (2009): "La almunia de al-Rusafa en Córdoba”, Madrider Mittelungen. № 50. Madrid, Deutschen Archäologischen Institut, pp.449-482.

MURILLO, Juan F., FUERTES, M. Camino y LUNA, Dolores (1999): "Aproximación al análisis de los espacios domésticos en la Córdoba andalusí", en GARCÍA VERDUGO, P. y ACOSTA, F. (coords.): Córdoba en la Historia. La construcción de la urbe, Córdoba, pp. 129-154.

MURILLO, Juan F. y JIMÉNEZ, José L. (2002): "Nuevas evidencias sobre la fundación de Corduba y su primera imagen urbana" en JIMÉNEZ, J. L. y RIBERA, A. (coords.): Valencia y las primeras ciudades romanas de Hispania (Grandes Temas Arqueológicos 3), Valencia, pp. 183-193.

MURILLO REDONDO, J. F., HIDALGO PRIETO, R., LÓPEZ LÓPEZ, I., FUERTES SANTOS, C. y GONZÁLEZ VIRSEDA, M. (2003): "Informe-Memoria de la I.A.U. en las manzanas 1.10 y 1.11 de Plan Parcial Renfe (Córdoba)", Anuario Arqueológico de Andalucía 2000 / III Actividades de Urgencia, Sevilla, Junta de Andalucía, pp. 370-396.

MURILLO REDONDO, Juan Francisco, CASAL GARCÍA, María Teresa y CASTRO DEL RÍO, Elena (2004): "Madinat Qurtuba. Aproximación al proceso de formación de la ciudad emiral y califal a partir de la información arqueológica", Cuadernos de Madinat Qurtuba. № 4. Córdoba, Junta de Andalucía, pp. 257-290.

MURILLO REDONDO, JUan F., CASTILLO PÉREZ DE SILES, Fátima, CASTRO DEL RÍO, Elena, CASAL GARCÍA, Ma Teresa, DORTEZ CÁCERES, Teresa (2010): "La almunia y el arrabal de al-Rusafa, en el Yanib al-Garbi de Madinat Qurtuba". en VAQUERIZO GIL, Desiderio; MURILLO REDONDO, Juan Francisco: El anfiteatro romano de Córdoba y su entorno urbano. Análisis arqueológico (ss. I-XIII). Vol. II,,Córdoba, pp. 565-615.

MURILLO REDONDO, Juan F., LEÓN MUÑOZ, Alberto, CASTRO DEL RÍO, Elena, CASAL GARCÍA, Ma Teresa, ORTIZ URBANO, Raimundo, GONZÁLEZ RUIZ, Antonio José (2010): "La transición de la civitas clásica cristianizada a la madina islámica a través de las transformaciones operadas en las áreas suburbiales", en VAQUERIZO GIL, Desiderio; MURILLO REDONDO, Juan Francisco: El anfiteatro romano de Córdoba y su entorno urbano. Análisis arqueológico (ss. I-XIII). Vol. II, Córdoba, pp. 503-547.

MURILLO, Juan F., GUTIÉRREZ, Ma I., RODRÍGUEZ, M.C. y RUÍZ LARA, M.D. (2010): "El área suburbana occidental de córdoba a través de las excavaciones en el anfiteatro. Una visión diacrónica”, en VAQUERIZO GIL, Desiderio; MURILLO REDONDO, Juan Francisco: El anfiteatro romano de Córdoba y su entorno urbano. Análisis arqueológico (ss. I-XIII). Vol. I, Córdoba, pp. 311-328.

NAVARRO PALAZÓN, J. (1990): "La casa andalusí en Siyäsa: Ensayo para una clasificación tipológica”. La casa hispano-musulmana. Aportaciones de la arqueología, Granada, pp. 177-198. 
NAVARRO PALAZÓN, J. (1997): Platería 14. Sobre cuatro casas andalusies y su evolución (siglo X-XIII), Murcia.

NAVARRO PALAZÓN, Julio y JIMÉNEZ CASTILLO, Pedro (1995): "El agua en la vivienda andalusí: abastecimiento, almacenamiento y evacuación”, Verdolay, № 7, Murcia, Museo Arqueológico de Murcia, pp. 401-412.

NAVARRO PALAZÓN, J. y JIMÉNEZ CASTILLO, P. (1996): "Estudio sobre once casas andalusíes en Siyâsa", Memorias de Arqueología, no 5, 1990, Murcia, pp. 526-595.

NAVARRO PALAZÓN, J. y JIMÉNEZ CASTILLO, P. (2003): "Sobre la ciudad islámica y su evolución", Estudios de Arqueología dedicados a la profesora Ana María Muñoz Amilibia, Murcia, Universidad de Murcia, pp. 319-381.

NAVARRO PALAZÓN, J. y JIMÉNEZ CASTILLO, P. (2004), «Evolución del paisaje urbano andalusí. De la Medina dispersa a la saturada», en Roldán Castro, F. (coord.), Paisaje y naturaleza en al-Andalus, Fundación El Legado Andalusí, Granada, 2004, pp. 232-267.

NAVARRO PALAZÓN, J. y JIMÉNEZ CASTILLO, P. (2007a): Las ciudades de Alandalús. Nuevas perspectivas, Zaragoza, Instituto de Estudios Islámicos y del Oriente Próximo

NAVARRO PALAZÓN, J. y JIMÉNEZ CASTILLO, P. (2007b): Siyâsa. Estudio arqueológico del despoblado andalusí (ss. XI-XIII), Murcia, Fundación El Legado Andalusí.

NAVARRO PALAZÓN, J. y JIMÉNEZ CASTILLO, P. (2009): "Arqueología del baño andalusí", Actas de los XIX cursos monográficos sobre el Patrimonio Histórico, Santander/ Reinosa, pp. 95-137.

NAVARRO PALAZÓN, J. y JIMÉNEZ CASTILLO, P. (2010): “E agua en la ciudad andalusi", Actas del II Coloquio Internacional Irrigación, Energía y Abastecimiento de Agua: La cultura del agua en el arco mediterráneo. Alcalá de Guadaíra, Ayuntamiento de Alcalá de Guadaíra, pp. 147-254.

NAVARRO PALAZÓN, J. y JIMÉNEZ CASTILLO, P. (2012): "La gestión del agua en la ciudad andalusí: el caso de Murcia", Patrimonio hidráulico y cultura del agua en el Mediterráneo, Murcia, Fundación Séneca, Campus Mare Nostrum, AECID, pp. 105-143.

OCAÑA JIMÉNEZ, Manuel (1963): "Notas sobre la Córdoba de Ibn Hazm", Al-Mulk. Anuario de Estudios Arabistas, 3 , pp. 53-62.

OLMO ENCISO, L (2001): “Ciudad y procesos de transformación social entre los siglos VI y IX: de Recópolis a Racupel", Visigodos y Omeyas. Un debate entre la Antigüedad Tardía y la Alta Edad Media (I Simposio Internacional de Mérida, 1999), Anejos de Archivo Español de Arqueología, XXIII, pp. 385-400.

PAVÓN MALDONADO, Basilio (1990): Tratado de arquitectura hispano-musulmana (Agua). Vol. 1. Madrid, CSIC.

PAVÓN MALDONADO, Basilio (1992): Ciudades Hispanomusulmanas, Madrid.

PINILLA MELGUIZO, Rafael (1999): "Saneamiento urbano y medio ambiente en la Córdoba islámica (siglos VIIIXIII)", Las ordenanzas de limpieza de Córdoba (1498) y su proyección. Córdoba, Universidad de Córdoba, pp. 39-54.
PIZARRO BERENGENA, Guadalupe (2009-2010): "El alcantarillado árabe de Córdoba II. Evidencia arqueológica del testimonio historiográfico", Anejos de Anales de Arqueología Cordobesa, n 2, Córdoba, Universidad de Córdoba, pp. 231-246.

PIZARRO BERENGENA, G. (2010): "La infraestructura de abastecimiento. Acueductos y qanawat al occidente de Córdoba", en VAQUERIZO GIL, Desiderio; MURILLO REDONDO, Juan Francisco: El anfiteatro romano de Córdoba y su entorno urbano. Análisis arqueológico (ss. I-XIII). Vol. 1, Córdoba, pp. 82-98.

PIZARRO BERENGENA, G. (2012): El abastecimiento de agua a Córdoba. Arqueología e Historia, Universidad de Córdoba, Córdoba.

REKLAITYTE, leva (2007): "Importancia y aprovechamiento del agua en el mundo islámico", Salduie, no 7 , Zaragoza, Universidad de Zaragoza, pp. 159-174.

RODERO PÉREZ, Santiago y ASENSI LLÁCER, María José (2006): "Un sector de la expansión occidental de la Córdoba islámica: el arrabal de la Carretera de Trassierra (II). Sector Central", Romula. № 5. Sevilla, Universidad Pablo de Olavide, pp. 295-336.

RODERO PÉREZ, S. y MOLINA MAHEDERO, Juan Antonio (2006): "Un sector de la expansión occidental de la Córdoba islámica: el arrabal de la Carretera de Trassierra (I)", Romula, n 5, Sevilla, Universidad Pablo de Olavide, pp. 219-294.

RUIZ LARA, D., MURILLO REDONDO, J. F. Y MORENO ALMENARA, M. (2001): "Memoria de los trabajos arqueológicos efectuados por la G.M.U. en el "vial H" del Polígono 3 del Plan Parcial de Poniente y en la unidad de actuación P-6 del P.G.O.U. de Córdoba (1995-1997)", Anuario Arqueológico de Andalucía 1997, / III Actividades de Urgencia, Sevilla, Junta de Andalucía pp. 148-162.

RUIZ LARA, D., MURILLO REDONDO, J. F., CARRILLO DÍAZ-PINES, J.R., CARMONA BERENGUER, S. y MORENO ALMENARA, M. (2003): "Resultados de la intervención arqueológica realizada en el Palacio de Orive de Córdoba (1996-1998)", Anuario Arqueológico de Andalucía 2000 / III Actividades de Urgencia, Sevilla, Junta de Andalucía pp. 299-321.

RUIZ LARA, D., SÁNCHEZ MADRID, S., CASTRO DEL RÍO, E., LEÓN MUÑOZ, A. y MURILLO REDONDO, J. F. (2008): "La ocupación diacrónica del Ŷanib al-Garbī de Qurțuba. Intervenciones arqueológicas realizadas en el Zoológico Municipal de Córdoba. Análisis de conjunto", en Anejos de Anales de Arqueología Cordobesa. № 1. Córdoba, Universidad de Córdoba, pp. 163-200.

RUIZ LARA, D., CASTRO DEL RÍO, E., LEÓN MUÑOZ, A., SÁNCHEZ MADRID, S. (2010): "El sector meridional del Yanib al-Garbi", en VAQUERIZO GIL, Desiderio; MURILLO REDONDO, Juan Francisco: El anfiteatro romano de Córdoba y su entorno urbano. Análisis arqueológico (ss. I-XIII). Vol. II, Córdoba, pp. 629-642.

RUIZ NIETO, E. (1999): "Intervenciones Arqueológicas en el Polígono de Poniente durante los años 1993 y 1994", Anuario Arqueológico de Andalucía 1994 / III Actividades de Urgencia, Sevilla, Junta de Andalucía, pp. 104-112. 
RUIZ NIETO, E. (2001): "Intervenciones Arqueológicas en el Polígono de Poniente (P3) (Córdoba)", Anuario Arqueológico de Andalucía 1996 / III Actividades de Urgencia, Sevilla, Junta de Andalucía, pp. 69-79.

RUIZ NIETO, Eduardo (2005): "El ensanche occidental de la Córdoba califal", Meridies. No 7. Córdoba, Universidad de Córdoba, pp. 59-74.

SALINAS PLEGUEZUELO, Elena (2012): La cerámica islámica de Madinat Qurtuba de 1031 a 1236: Cronotipología y centros de producción. Tesis doctoral, Universidad de Córdoba.

SALVATIERRA, V., SERRANO, J. L. y PÉREZ, Ma C. (1998): "La formación de la ciudad en al-Andalus. Elementos para una nueva propuesta" en CRESSIER, P. et GARCÍA M. (Eds.), Genese de la ville islamique en al-Andalus et au Maghreb occidental, Madrid, pp. 185-206.

TRILLO SAN JOSÉ, Carmen (2009): El agua en al-Andalus. Málaga.

VALLEJO TRIANO, A. (2010): La ciudad califal de Madinat al-Zahrā'. Arqueología de su excavación, Córdoba.

VAN STAËVEL, Jean-Pierre (1995): "Casa, calle y vecindad en la documentación jurídica”, en NAVARRO PALAZÓN, J. (coord.): Casas y palacios en al-Andalus. BarcelonaGranada, pp. 53-61.

VAQUERIZO, Desiderio y MURILLO, J.F. (Eds.) (2010): El anfiteatro romano de Córdoba y su entorno urbano. Análisis arqueológico (ss. I-XIII d.C.), Monografías de Arqueología Cordobesa n 19, Córdoba.

VÁZQUEZ NAVAJAS, Belén (2010): "La gestión del agua en los arrabales occidentales de Madinat Qurtuba", en VAQUERIZO GIL, Desiderio; MURILLO REDONDO, Juan Francisco: El anfiteatro romano de Córdoba y su entorno urbano. Análisis arqueológico (ss. I-XIII). Vol. II, Córdoba, pp. 643-651.
VÁZOUEZ NAVAJAS, B. (2013): "El agua en la Córdoba andalusí. Los sistemas hidráulicos de un sector del Ŷānib al-Garbì durante el Califato Omeya", Arqueología y Territorio Medieval, n² 20, Jaén, pp. 31-66.

VÁZQUEZ NAVAJAS, B. (2016): Arqueología hidráulica en los arrabales occidentales de la Córdoba omeya, Córdoba.

VENTURA, Ángel y BERMÚDEZ, José Manuel (1992): "Avance de resultados de la I.A.U. en el polideportivo Vista Alegre (Córdoba)", Anuario Arqueológico de Andalucía 1990 / III Actividades de Urgencia, Sevilla, Junta de Andalucía, pp. 105-112.

VIDAL CASTRO, Francisco (2000): "Agua y urbanismo: evacuación de aguas en fatwà-s de al-Andalus y el Norte de África" en CRESSIER, P.; FIERRO, M., VAN STAËVEL, J.P.: L'urbanisme dans l'occident musulman au Moyen Âge: aspects juridiques, Madrid, pp. 101-124.

VIDAL CASTRO, Francisco (2008): "La transmisión del uso y gestión del agua de al-Andalus al mundo cristiano", en ROLDÁN CASTRO, F. y DELGADO PÉREZ, M. (eds.): Las huellas del Islam, Huelva (Collectanea Universidad de Huelva, 122), pp. 163-187.

VIDAL CASTRO, Francisco (2009): "El derecho de aguas en el Islam. Teoría y fundamentos institucionales", "en línea”: www.unizar.es/eueez/cahe/vidal.pdf.

ZAMORANO ARENAS, A. M. y LUNA OSUNA, D. (1995): "Excavación arqueológica de urgencia en el Sistema General U-1 (Finca Fontanar, Córdoba)", Anuario Arqueológico de Andalucía 1992 / III Actividades de Urgencia, Sevilla, Junta de Andalucía, pp. 161-174. 